\title{
PERSPECTIVES ON THE QUECHUA-AYMARA CONTACT RELATIONSHIP AND THE LEXICON AND PHONOLOGY OF PRE-PROTO-AYMARA ${ }^{1}$
}

\author{
Nicholas Q. EmLen \\ LEIDEN UNIVERSITY
}

\begin{abstract}
The complex, multilayered contact between the Quechuan and Aymaran languages is a central but still poorly understood issue in Andean prehistory. This paper proposes a periodization of that relationship and characterizes some aspects of the languages as they might have existed prior to their first contact. After disentangling the linguistic lineages on the basis of a large corpus of lexical data, the paper makes some observations about the phonology of Pre-Proto-Aymara: first, about aspiration and glottalization; second, about the glottal fricative $* \mathrm{~h}$; and third, about the phonotactic structure of lexical roots. The paper also presents lexical reconstructions of Proto-Aymara and Proto-Quechua and proposes provenances for several hundred roots. More than a third of the reconstructed Proto-Aymara lexicon may originate in Proto-Quechua. A method like the one presented here is a prerequisite for testing a hypothesis of genetic relatedness between the two families (and others in the region).
\end{abstract}

[KeYwords: Quechua, Aymara, language contact, Andean prehistory]

1. Introduction. The Quechuan and Aymaran languages of the Central Andes represent a complex, multilayered case of language contact. Over the course of their long shared history, they have come to exhibit striking structural and phonological resemblances as well as a large quantity of shared lexical items. These similarities have led to centuries of speculation about whether the language families descend from a common proto-language (for an overview of this history, see Cerrón-Palomino 1987:351-75, 2000:298-337); but since the beginning of the comparativist period of Andean linguistics in the 1960s, a broad (though not total) consensus has been reached that these resemblances are best explained as the result of language contact.

Despite general agreement on this point, the historical nature of QuechuanAymaran language contact itself has not been systematically investigated, nor

${ }^{1}$ Thanks to Willem Adelaar, Bruce Mannheim, Rodolfo Cerrón-Palomino, Matthias Urban, Zachary O'Hagan, and two anonymous IJAL reviewers, who all provided detailed comments on earlier versions of this paper. Remaining infelicities are mine alone. Thanks also to Nicolas Brucato and Sandhya Narayanan. The research leading to these results received funding from the European Research Council under the European Union's Seventh Framework Programme (FP7/2007-2013)/ERC grant agreement no. 295918.

[IJAL, vol. 83, no. 2, April 2017, pp. 307-40]

(C) 2017 by The University of Chicago. All rights reserved.

0020-7071/2017/8302-0005\$10.00 
has an attempt been made to establish provenances for the great number of shared lexical items. It has also remained unclear what the languages may have been like before their first contact. This is due in part to the sheer complexity of the Andean linguistic panorama, where in some places structural and lexical continuities correlate only loosely with internal and external genetic groupings, and in which the expansion, retraction, and disappearance of countless linguistic varieties across the western South American sociolinguistic palimpsest have made it very difficult to assemble a coherent history of the region's languages. This effort has also been limited by the inconsistent and often sparse documentation of each family's varieties, though descriptive work in the Andes has resumed after an initial burst in the 1960s and 1970s. Linguists have also begun to gather valuable insights through the examination of documents from the colonial period.

This paper attempts to clarify some aspects of the history of QuechuanAymaran contact by (1) characterizing, in the broadest terms, the various periods of lexical borrowing that have taken place between the two families, (2) assigning provenances to as many lexical items as possible, and (3) using a rough relative chronology of contact to strip away the successive layers of borrowing and shed light on what the lexicons and phonologies of the languages - in particular, the ancient ancestor of the Aymaran lineage-might have been like before their first contact. Contact between the languages appears to be quite old: many of the shared lexical items can be reconstructed in both Proto-Quechua and Proto-Aymara, suggesting that the first period of borrowing began before the proto-languages each ramified into their respective language families. Thus we must posit an earlier period in the history of both languages, before their first contact, which, following Cerrón-Palomino (2000) and Adelaar (2012a), among others, I call Pre-Proto-Quechua and Pre-ProtoAymara. Note that these terms should not be taken to refer to static languages but rather to the penultimate period before the ramification of the clades from which we have data. ${ }^{2}$ This paper focuses on the lexicon and phonology of Pre-Proto-Aymara, though much remains to be said about the early history of the Quechuan languages and about the history of morphological and syntactic convergence between both language families.

In order to establish a periodization of borrowing and reveal some of the lexical and phonological characteristics of the pre-proto-languages before the first period of contact, this paper follows and expands on the methods proposed by Adelaar (1986) for separating the lexicons of the Quechuan and Aymaran languages. The insight of that proposal is that, besides their great number of shared lexical items, each family also has a substantial proportion of non-shared lexical items. The latter group, all things being equal, likely

\footnotetext{
${ }^{2}$ I am grateful to an anonymous reviewer for suggesting this formulation.
} 
descended from the period before the initial contact between the pre-protolanguages and thus is more likely to exhibit the phonological and phonotactic characteristics of those languages. These characteristics can then be used as diagnostics to determine the directionality of borrowing of some of the shared lexical items. As is discussed in detail in $\mathbf{4}$ below, this methodology was implemented in the following manner: first, I reconstructed a set of 566 Proto-Quechua and 496 Proto-Aymara lexical items, which are listed in Appendix A (available online only). Second, I isolated the non-shared lexicon of each proto-language by determining which of the reconstructed items were unattested in any source in the other family (with the exception of Bertonio's 1612 Aymara dictionary, which borrows liberally from Quechua) (see 4). Third, I analyzed the phonological features exhibited by those non-shared lexical items. This paper focuses on the aspirated and glottalized consonants (whose presence earlier in Pre-Proto-Aymara is unclear, as discussed in 4.3.2), the glottal fricative $* \mathrm{~h}$, and the glides $*_{\mathrm{w}}$ and $*_{\mathrm{y}}$. Beyond this, confirming Adelaar's (1986) hypothesis, I also found that syllable-final non-resonants and word-final consonants likely existed in Pre-Proto-Quechua but not in Pre-Proto-Aymara. Finally, these patterns were used, where possible, as diagnostic features for identifying the likely origin of the shared lexical items (4.4). These provenances are listed along with the Proto-Quechua and Proto-Aymara lexical reconstructions in Appendix A (available online only). According to my sorting of the lexicon, the directionality of borrowing appears to have been overwhelmingly from Pre-Proto-Quechua to Pre-Proto-Aymara, and more than a third of the Proto-Aymara lexicon may ultimately originate in the Quechuan lineage.

This paper does not directly address the question of a Quechuan-Aymaran genetic grouping but rather provides a new perspective on what some aspects of the languages might have been like before the contact responsible for their great quantity of obviously shared lexical items. Of course, if a hypothesis of genetic relatedness between the Quechuan and Aymaran families - that is, between Pre-Proto-Quechua and Pre-Proto-Aymara-is ever to be adequately tested, the sort of procedure described in this paper for approximating the lexicons of those languages is a methodological prerequisite (as pointed out by Parker 1969b, 1973; Adelaar 1986; Campbell 1995). It is also necessary, as illustrated in this paper, to disengage the historical status of glottalization and aspiration from the question of a Quechuan-Aymaran grouping if that effort is to move forward. However, given the large time depth of these phenomena, it is perhaps more productive to consider broader regional connections than to continue re-addressing the specific question of a Quechuan-Aymaran relationship (Adelaar 1986, 2013). That said, there are still a number of resemblances between the Quechuan and Aymaran languages (for instance, a substantial number of lexical similarities) when 
all identifiable strata of borrowing are stripped away. This situation remains to be explained.

2. A multilayered history of convergence. The Quechuan and Aymaran languages are spoken across a broad and overlapping expanse of western South America (for a thorough overview of both families, see Adelaar and Muysken 2004:165-319). The Quechuan languages (ISO code: que), which together have several million speakers, are found from northern Argentina and Chile in the south to southern Colombia in the north and have been spoken in various parts of the Andes, Western Amazonia, and the Pacific Coast throughout their history. The Aymaran languages (ISO code: aym) are spoken by 2-3 million people in parts of southern Peru, Bolivia, and northern Chile, as well as in a handful of villages several hundred kilometers further north in the central Peruvian department of Lima. It is clear that Aymaran languages were once more widespread in southern and central Peru, but that many of these languages have since disappeared (Adelaar and Muysken 2004:260; Mannheim 1991:43-47) (see 2.1 below). Some of the varieties of each family are very vital and are spoken by people of all ages (including many monolinguals) despite some shift to Spanish. Other varieties are spoken by only a handful of elderly people.

These families and their sub-branches have gone by many names in the linguistic literature. In this paper, I follow Cerrón-Palomino (2000) and Adelaar (2012a) in referring to the two extant branches of the Aymaran family as Central Aymaran and Southern Aymaran. The Central Aymaran varieties are spoken in the central Peruvian department of Lima, and the Southern Aymaran varieties are spoken in some highland areas of southern Peru, Bolivia, and northern Chile. The Quechuan languages are divided into two major branches. The first is a group of varieties spoken in central Peru, called Quechua I by Torero (1964), Quechua B by Parker (1963), and Central Quechua by Mannheim (1991); the second comprises varieties spoken both in the northern and southern reaches of the Quechuan range outside of central Peru (called Quechua II by Torero, Quechua A by Parker, and Peripheral Quechua by Mannheim). Most Andeanists today use Torero's Quechua I/II terminology, and I follow that practice in this paper. The Quechua II branch is further divided into the Northern (IIB) and Southern (IIC) sub-branches; the so-called Quechua IIA varieties have turned out not to be a convincing genealogical grouping. Thus the Quechuan varieties that do not fit straightforwardly into this scheme (for instance, Pacaraos, Cajamarca, and Yauyos) are indicated by name in this paper.

The structural-typological and phonological similarities between the Quechuan and Aymaran families are profound (e.g., Cerrón-Palomino 1994), and the languages share a great quantity of lexical items. According to common estimates, going back to Tschudi (1884:77), some 15-30\% of the basic vocabulary of each family is common to both of them (see also Middendorf 1891; Adelaar 
1986; Cerrón-Palomino 2000:311). Before the comparativist period in Andean linguistics beginning in the 1960s, these resemblances were often invoked as evidence of genetic relatedness. However, since then it has been broadly agreed that they are better explained as a result of language contact (for a contrary position, see Orr and Longacre 1968). For example, an interpretation of the $15-30 \%$ of shared lexicon as a shared genetic inheritance raises the problem of how to account for the $70-85 \%$ of obviously non-shared lexicon (particularly since most of the shared lexical items are identical or nearly identical in each family), as well as the fact that the non-basic vocabularies of the families are shared to a greater extent than their basic vocabularies (Heggarty 2005, 2011). Furthermore, the coincidence of aspirated and glottalized consonants in the Aymaran languages and in some of the Quechuan varieties of southern Peru and Bolivia-one of the most suggestive similarities to proponents of a Quechuan-Aymaran genetic grouping - is best explained as the result of recent contact rather than shared inheritance. It also now appears that the structural resemblances between the families are due to a profound remodeling of Quechua morphosyntax on the Aymaran model (Adelaar and Muysken 2004:36; Muysken 2011), rather than to shared inheritance. These processes are attributable to a long and close relationship of contact, in which sustained and intimate multilingualism began centuries or millennia ago at the proto-language stage and continued within and between the many branches and sub-branches of each family to the present day.

In a first attempt to bring order to the tangled history of Quechuan-Aymaran convergence, Adelaar (1986) makes the important observation that not all of the shared lexical items are shared in the same way. Looking at a broad sample from each language family, it is clear that some items are robustly attested across both families, while others predominate in one family but are only sporadically attested in the other, and others still are attested only among Quechuan and Aymaran varieties in a small geographic area. Table 1 gives examples of each of these patterns. ${ }^{3}$ The items in $(a)$ are shared across all of the attested varieties of both families and can be reconstructed in both Proto-Aymara and Proto-Quechua. In ( $b)$, *urqu 'mountain' and *qipa 'behind (space), after (time)' are attested across the Quechuan family and can be reconstructed in Proto-Quechua but are attested only sporadically in the Aymaran languages. On the other hand, $(c)$ gives the example of the pan-Aymaran noun *haynu 'husband', which can be reconstructed in Proto-Aymara but is attested only sporadically in the Quechuan languages. Finally, $(d)$ lists items that are shared locally among neighboring varieties of Quechuan and Aymaran languages (e.g., Central Aymaran and Yauyos Quechua in central Peru, and Southern Aymaran and Cuzco Quechua in southern Peru and Bolivia), but

3 Abbreviations used in this paper are: Jaq (Jaqaru, Central Aymaran), Lup (Lupaca, Southern Aymaran), PA (Proto-Aymara), Jun (Junín, Quechua I), Yau (Yauyos Quechua), Ec (Ecuadorian, Quechua IIB), Cuz (Cuzco, Quechua IIC), PQ (Proto-Quechua). 
TABLE 1

Some Shared Lexical Items in Aymaran and Quechuan Languages

\begin{tabular}{|c|c|c|c|c|c|c|c|c|}
\hline \multirow[b]{2}{*}{ Gloss } & \multicolumn{3}{|c|}{ Aymaran } & \multicolumn{5}{|c|}{ Quechuan } \\
\hline & $\mathrm{Jaq}$ & Lup & PA & Jun & Yau & Ec & Cuz & PQ \\
\hline \multicolumn{9}{|l|}{ (a) } \\
\hline $\begin{array}{l}\text { 'to carry, } \\
\text { bring' }\end{array}$ & apa- & apa- & *apa- & apa- & apa- & apa- & apa- & *apa- \\
\hline 'five' & pičqa & $\begin{array}{l}\text { pisqa } \\
\sim p^{h} i s q a\end{array}$ & *pičqa & pičqa & pičqa & pička & $p^{h} i s q a$ & *pičqa \\
\hline \multicolumn{9}{|l|}{ (b) } \\
\hline 'mountain' & urqu & $q u \kappa u$ & & urqu & urqu & urku & urqu & *urqu \\
\hline $\begin{array}{l}\text { 'behind } \\
\text { (space), } \\
\text { after (time)' }\end{array}$ & qurqa & $q^{h} i p a$ & & qipa & qipa & kipa & $q^{h} i p a$ & *qipa \\
\hline \multicolumn{9}{|l|}{ (c) } \\
\hline 'husband' & haynu & hаупи & *haynu & qusa & qusa & kusa & $\begin{array}{l}\text { qusa, } \\
\text { haynu }\end{array}$ & $\begin{array}{l}\text { *qusa } \\
\text { 'camelid stud' }\end{array}$ \\
\hline \multicolumn{9}{|l|}{$(d)$} \\
\hline $\begin{array}{l}\text { 'to beat } \\
\text { (heart), } \\
\text { heartbeat' }\end{array}$ & pikpiki & tixtixtitu & & & pikpikya- & & tiktik & \\
\hline
\end{tabular}

which can be reconstructed in neither proto-language. Note that the data given in table 1 and elsewhere in this paper come from the database developed from the sources listed in $\mathbf{3}$ below, and all reconstructed lexical items cited in the paper are listed in Appendix A (available online only). When lexical items from the database are presented in this paper, they are not cited by source.

These distributional patterns can be interpreted chronologically, as the result of successive periods of lexical borrowing that took place at different moments in the history of the language families. To begin with, the lexical items that can be reconstructed in both proto-languages (category $a$ in table 1) were most likely borrowed before those proto-languages each split apart into their respective language families. Adelaar calls this the period of "initial convergence" (2012b:464, and elsewhere), which featured a large amount of borrowing in both the basic and non-basic lexicon. As mentioned above, the presence of such loans in the earliest periods of Proto-Quechua and ProtoAymara that can be reconstructed requires that we posit an earlier pre-protolanguage stage for each language. Note that almost all of the items that can be reconstructed in both Proto-Quechua and Proto-Aymara are identical or nearly identical, suggesting that the formation of the Quechuan and Aymaran families took place during or soon after this period of intense contact between Pre-Proto-Quechua and Pre-Proto-Aymara. ${ }^{4}$ Table 2 provides a small sample

${ }^{4}$ A smaller number of apparent correspondences that are not as similar in form (Campbell 1995; Cerrón-Palomino 2000:311-12) are discussed in $\mathbf{4 . 2}$ below. 
TABLE 2

Some Shared Proto-Quechua and Proto-Aymara Lexical Items

\begin{tabular}{|c|c|c|}
\hline & Proto-Quechua & Proto-Aymara \\
\hline 'fish' & *čaKwa & *čaKwa \\
\hline 'ear of corn' & $*$ čuq $\mathrm{Ku}$ & $*$ čuq $\Lambda \mathrm{u}$ \\
\hline $\begin{array}{l}\text { 'to impede, block, detain, } \\
\text { obstruct' }\end{array}$ & *harka- & *hark'a- \\
\hline 'same, self' & *kiki & *kiki \\
\hline 'three' & *kimsa & *kimsa \\
\hline 'time, occasion' & *kuti & *kuti \\
\hline 'soft, smooth' & * Kampu & *Kamp'u \\
\hline 'slippery, to slip, slide' & *Kučka- & *Kučka- \\
\hline 'stingy' & *mitşa & *mitş’a \\
\hline 'fire' & *nina & $*_{\text {nina }}$ \\
\hline 'hundred' & *patşak & *patsaka \\
\hline 'to break, smash' & *paki- & *p'aki- \\
\hline 'waterfall, stream of water' & *paqča & *paqča \\
\hline 'five' & *pičqa & *pičqa \\
\hline 'six’ & *suqta & *suqta \\
\hline
\end{tabular}

of shared Proto-Quechua and Proto-Aymara items that were likely borrowed during the initial convergence (see Appendix A [available online only] for the full reconstructions).

The period of initial convergence between Pre-Proto-Quechua and PreProto-Aymara gave rise to Proto-Quechua and Proto-Aymara, the earliest states that can be reconstructed through comparison of their attested daughter languages. Note, however, that a great number of daughter languages may have disappeared before being attested, which limits the ethnohistorical conclusions that can be drawn about the proto-languages (particularly with respect to time depth).

At this point, Proto-Quechua and Proto-Aymara each began to diverge into the distinct branches and sub-branches of their respective language families as they moved across the region from their likely point of origin in central Peru (see 2.1). Intense subsequent contact took place between and among the daughter languages of each proto-language as a result of local interaction or wider regional economic and political integration (for instance, during the Inka period). Following Adelaar (2012b:463), the contacts that took place after Proto-Quechua and Proto-Aymara split into families are referred to as "local convergences." This period includes the shared lexical items in categories $(b)$ and $(c)$ in table 1 , which can be reconstructed in one proto-language but not the other, as well as those in category $(d)$, which are attested in neighboring Quechuan and Aymaran varieties but cannot be reconstructed in either proto-language. The period of local convergence continues to the present day, as Quechuan-Aymaran multilingualism persists in parts of Bolivia (Bastien 
1978; Hosókawa 1980; Howard 2007), Puno and some of the islands of Lake Titicaca (Sandhya Narayanan, personal communication), and likely in other places where documentation is sparser. These localized contacts account for the borrowing of aspiration and glottalization from Southern Aymara into the Quechua varieties in southern Peru and Bolivia (Mannheim 1991) (see 4.3.2) and the borrowing of Aymara suffixes into some varieties of Quechua in Puno (Adelaar 1987) and Colca (Rodolfo Cerrón-Palomino, personal communication). It is likely that Quechua-Aymara bilingualism (in addition to multilingualism in other languages) was more intense during the colonial period than it is today, as attested in early accounts of the bewildering sociolinguistic mosaic of the Andes (Mannheim 1991:43-47) and the almost unrestrained borrowing of Quechuan roots visible in Ludovico Bertonio's early Aymara missionary dictionary (1612), which suggests that some of the people living around Lake Titicaca could understand Quechua just as well as they understood Aymara. The long and heterogeneous period of local convergences has also included contact with a great number of other languages in the Andes, the Pacific Coast, and the Amazonian lowlands (Emlen 2016); indeed, it is also possible that the initial convergence itself involved other (perhaps longextinct) languages about whose existence one can only speculate.

2.1. Ethnohistorical considerations. An important question for Andeanists has been when and where the Aymaran and Quechuan lineages emerged and began their initial contact, and how the subsequent development of the two families fits into archaeological accounts of Andean prehistory (Cerrón-Palomino 1987, 2000, 2013; Torero 2002; Heggarty and Beresford-Jones 2012). If we accept, impressionistically, that the diversity among the currently attested Quechuan and Aymaran languages is roughly comparable to that of the Romance languages (Heggarty and BeresfordJones 2010:172), then the initial period of convergence before the formation of the families may have taken place at around the same time depth. It is impossible to know how much earlier than this the initial period of interaction began, but we may be dealing with a time before the common era. This is a useful starting place, though using linguistic distance as a proxy for time depth in this case-either relative or absolute-is risky because (setting aside the other commonly cited methodological problems with glottochronology) it is unlikely that the currently attested varieties represent the full range of daughter languages that descended from each ancient language. If there was once, for instance, a now-extinct "Northern Aymaran" branch that lay beyond the currently reconstructible Aymaran clade-a highly plausible scenario, if in fact Pre-Proto-Aymara originated to the north of its current distribution - then a reconstruction of Proto-Aymara based on the extant varieties would not match the ancient language that we might imagine corresponding to prehistoric populations and events. We must 
keep in mind that the indigenous population of Peru may have decreased by more than $90 \%$ as a result of the devastating pandemics and disruptions of the colonial period (Wachtel 1977; Cook 1981:114), and the subset of languages that survived that demographic bottleneck was then dramatically reconfigured within the colonial sociolinguistic ecology (Mannheim 1991; Durston 2007). Thus, the languages that happened to survive long enough to be documented are probably insufficient to build a totalizing picture of the ancient Andean linguistic panorama. ${ }^{5}$

But while the specific historical circumstances surrounding the emergence and early development of the Quechuan and Aymaran lineages may be lost to time, some useful geographic conclusions can be gleaned from the linguistic facts. For instance, there is some agreement that the Quechuan languages likely emerged in what is now central Peru, since that region is the center of the family's diversity and since many of the most archaic features of Quechua are found there (Adelaar 2012a:587). Furthermore, if one sets aside the apparently more recent expansions of Quechua IIB in the north and Quechua IIC in the south, all of the remaining varieties are in central Peru. Given that the period of initial convergence must have taken place before the expansion of the Quechuan and Aymaran families, Pre-Proto-Aymara must also have been spoken, at least at that point, in the same area (Adelaar $2012 b: 465)$. This hypothesis is supported by the fact that central Peru is home to a dense concentration of Aymaran toponyms (see Middendorf 1891; CerrónPalomino 2000, 2008; Torero 2002), even though no Aymaran languages are currently attested north of the department of Lima. Furthermore, some central Peruvian varieties of Quechua exhibit local (that is, post-initial-period) Aymaran influence, including lexical borrowing and perhaps lexicalized suffixes (Cerrón-Palomino 2000:193, n. 16). Note, for instance, Pacaraos forms such as mayaaninta 'suddenly' from Aymaran maya 'one' (Adelaar 1982:35, 2010:251, n. 3) and pari tsupi 'soup heated with rocks', from Aymaran pari 'hot' (Willem Adelaar, personal communication) (see also Cerrón-Palomino 2008). Central Aymaran may also have been spoken in Canta (northeast of Lima) in the early twentieth century (Hardman 1966:15), and there is ample evidence of Aymaran languages around Lima more widely (Torero 2002:110). All of this suggests that Aymaran languages were widespread in central Peru

${ }^{5}$ Colonial sources refer to a bewildering array of (in many cases now-extinct) languages across central and southern Peru, some of which belonged to the Quechuan and Aymaran families, and some of which may have been unrelated. The discontinuous settlement pattern (e.g., Murra 1972) and islands of resettled mitmaqkuna that characterized the social fabric of the precolumbian Andes created a highly dynamic and noncontiguous sociolinguistic mosaic (Mannheim 1991:43-53) that was very different from the situation today. Note that there may once have been Aymaran and Quechuan languages in central Peru that lay outside the clades affected by the initial convergence (Adelaar 2010:243). 
until relatively recently, though it is not clear what those languages were like or if they belonged to the Central Aymaran branch.

The sociolinguistic context of the initial convergence is unknowable, but it is clear that these profound changes must have taken place within a situation of intense and stable intergenerational bilingualism. These contact effects may suggest particular demographic and sociopolitical configurations that can eventually be linked to the archaeological record (Adelaar 2010; BeresfordJones and Heggarty 2010; Muysken 2011), if only in the most general terms. However, it is important to avoid the anachronistic assumption that the two linguistic lineages corresponded to separate groups of Quechua- and Aymaraspeaking people ("Quechuas" and "Aymaras"), rather than to a principle of social differentiation within a single multilingual population, as they do in many areas of Quechuan-Aymaran contact today. ${ }^{6}$ Relatedly, the linguistic patterns of the initial period should not necessarily be interpreted as the product of broad regional integration - the initial convergence between PreProto-Quechua and Pre-Proto-Aymara may have been confined to a small multilingual population that emerged independently of large-scale political or demographic transformations.

3. Data. An approximation of the lexicons and phonological systems of Pre-Proto-Quechua and Pre-Proto-Aymara can only be accomplished by identifying and stripping away the many layers of borrowing between the two families to reveal a core of lexical items that likely descend from each language. The sheer complexity of the patterns of borrowing, produced in pockets of localized multilingualism as well as successive periods of regional integration, makes this a daunting task indeed, but the recent improvement in the quantity and quality of descriptive data (particularly in the crucial Central Aymaran varieties) allows for the kind of large-scale comparison necessary for identifying and interpreting patterns in the Quechuan and Aymaran lexicons. This section describes the data used in this paper, and $\mathbf{4}$ discusses the methods used to disentangle the lexicons of the two pre-proto-languages.

In order to generate a sample of Proto-Quechua and Proto-Aymara lexical roots that is both constrained by rigorous empirical standards and large enough to support analytic generalizations, a very large data set is required. My data include 22,103 individual lexical items (11,911 Quechuan and 10,192 Aymaran)

${ }^{6}$ Note, for instance, that while the practice of projecting the names of languages onto imagined populations was common in the colonial period and remains so in the modern ethno-political context of the Andean nations, it is seldom clear that such designations refer to anything beyond the domain of ideology, in the present or in the past. The notion of a continuous multilingual population is supported by ethnohistorical as well as genetic evidence, as indicated by GayàVidal et al. (2010, 2011). 
from 15 Quechuan sources and 10 Aymaran sources, chosen for maximum representation of each family's varieties. These consist of mostly bisyllabic (but also some mono-, tri-, and quadrisyllabic) non-morphologically complex lexical roots. ${ }^{7}$ These were arranged together, across the various Quechuan and Aymaran varieties, in 6,785 sets. Quechuan data come from Pacaraos (Adelaar 1982), Huanca (Cerrón-Palomino 1976), Ancash (Parker and Chávez 1976), Cajamarca (Quesada 1976), Yauyos (Shimelman, forthcoming), San Martín (Park, Weber, and Cenepo Sangama 1976), Ecuador (Cordero 1895/1992; Orr and Wrisley 1965/1981; Ministerio de Educación 2009), Chachapoyas-Lamas (Taylor 1979), Ayacucho (Parker 1969a), and Cuzco (González Holguín 1607; Cusihuamán Gutiérrez 1976; Academia Mayor de La Lengua Quechua 2005), as well as my own fieldwork with Quechua-Matsigenka-Spanish trilinguals in the Amazonian lowlands of Cuzco (Emlen 2014).

Southern Aymaran sources include Bertonio's Lupaca dictionary (1612), Deza Galindo's dictionary of Puno Aymara (1989), Mamani Mamani's dictionary of Northern Chile Aymara (2002), and Huayhua Pari's pan-dialectal Southern Aymaran dictionary (2009). Because the Central Aymaran varieties are so scarcely documented yet so crucial to understanding the Aymaran family, I assembled as much data from this branch as possible. Most of the data come from Belleza Castro's dictionary (1995). I also included the word lists provided by Hardman $(1966,1983)$, as well as my own analysis of the community manuscripts publicly available on the University of Florida Digital Collections website (<http://ufdc.ufl.edu/jaqi $>$ ). For the purposes of confirmation rather than reliable phonological attestations, I also consulted the early word lists published by Barranca (1876) — possibly originally collected by Tschudi some decades earlier (Cerrón-Palomino 2000:39, n. 13)— and by Farfán (1961). As mentioned earlier, all data in the paper come from the database compiled from these sources and are not cited by source. All reconstructed forms used in the paper are listed in Appendix A (available online only).

4. Methods. Once the data described in $\mathbf{3}$ were collected, I proceeded to use the methods detailed in this section to disentangle the Quechuan and Aymaran lexicons. First, I reconstructed as many Proto-Quechua and ProtoAymara lexical items as possible, within relatively strict empirical limits (4.1). Then I arranged these reconstructed lexical items into sets across the two language families and isolated the forms in each proto-language that were unattested in any of the other family's varieties (4.2). The one exception to this was Bertonio's Lupaca Aymara dictionary (1612), which incorporates a

${ }^{7}$ An important methodological step in constructing this data set is identifying and ruling out morphologically complex Aymaran forms, which are subject to vowel deletion rules that give a misleading impression of representing underlying phonological patterns. 
great number of Quechuan items and would unnecessarily constrain the ProtoQuechua sample. Thus Proto-Quechua forms that were attested in Bertonio's dictionary, but none of the other Aymaran sources, were left in the non-shared Proto-Quechua sample. I then conducted a phonological analysis of these non-shared portions of the Proto-Quechua and Proto-Aymara lexicons (4.3), which are mostly likely to represent the period before the initial convergence. Discussed here are the Proto-Aymara glottal fricative *h and its relationship to the glides $*_{\mathrm{y}}$ and $*_{\mathrm{W}}$ (4.3.1), the glottalized and aspirated consonants (4.3.2), and root-internal and root-final syllable codas (4.3.3). Finally, I posited provenances for the Proto-Quechua and Proto-Aymara lexical items (4.4), where possible, based on the diagnostic phonological features identified in $\mathbf{4 . 3}$ and on the distribution of the lexical items across the Quechuan and Aymaran varieties. These provenances are given in Appendix A (available online only) alongside the reconstructed forms.

4.1. Reconstruction of the Proto-Quechua and Proto-Aymara lexicons. To begin with, I reconstructed as many Proto-Quechua and ProtoAymara lexical roots as possible (a total of 566 and 496, respectively) on the basis of my 6,785 sets (see Appendix A [available online only]). The reconstructions are based on Cerrón-Palomino's accounts of the phonological development of the Quechuan (1987) and Aymaran (2000) families, and the Aymaran reconstructions and correspondences given in Cerrón-Palomino (2000:116-87, 344-69) and Parker (1969c) served as guides. Because the high degree of lexical borrowing that has taken place within each family presents challenges in distinguishing between cognates and borrowings, I observed a high empirical threshold in my reconstructions. Proto-Quechua items were reconstructed if they met two criteria: first, they must be attested in a Quechua I variety in central Peru, a Quechua IIB variety in the north, and a Quechua IIC variety in the south (the most tree-like domains of the Quechuan family and the most geographically dispersed), as well as in one other variety outside of these branches (Yauyos, Cajamarca, or Pacaraos, which are all relatively conservative but do not fit easily into a branching model of the Quechuan family). This allows for a broad representation across the language family and across the Andean region (an important requirement for a family with substantial inter-dialectal lexical continuity) while still offering enough flexibility to generate an adequate sample. Second, the items must exhibit the sound correspondences known to be generated by the phonological innovations in each branch (Cerrón-Palomino 1987, 2000). ${ }^{8}$ This method is subject to some errors: surely some lexical items were borrowed across the Quechuan varieties after the ramification of the

\footnotetext{
${ }^{8}$ My reconstructed lexicon differs somewhat from that of Parker (1969c): in some cases, I did not reconstruct roots that did not meet my empirical threshold, and in other cases the availability of new data allowed me to reconstruct roots not listed in that work.
} 
family and then took on the phonological characteristics of those varieties. However, despite inevitable historical exceptions, descent from the protolanguage remains the most parsimonious account for items that meet these relatively stringent criteria.

Reconstructing Proto-Aymara roots presents a rather different set of challenges. On the one hand, only two Aymaran branches survive with which to build a cognate set; on the other hand, there does not appear to have been much borrowing between the two widely separated branches after the family was formed, making each cognate set more credible. Therefore, Proto-Aymara lexical items were reconstructed (1) if they are attested in both the Central and Southern branches of the family; (2) if they exhibit the sound correspondences known to be generated by the phonological innovations in the two branches; and (3) in the cases in which cognates were also attested in one or more varieties of Quechua, if they are also attested in Chilean Aymara (Mamani Mamani 2002). This well-documented group of Aymaran varieties lies definitively beyond the modern Quechua interaction zone, so it offers a useful extra comparison in cases of shared correspondences with Quechua. Again, the method is subject to some errors: it is likely, for instance, that some of these reconstructed items were borrowed independently from Quechuan languages into the Central and Southern branches rather than during the initial period of convergence. However, on balance, this is the most empirically conservative procedure for generating a sample large enough to form generalizations about Pre-Proto-Aymara phonology.

4.2. Separation of the shared and non-shared lexicon. Next, I categorized the reconstructed Proto-Quechua and Proto-Aymara lexical items as non-shared (unattested in the other family's varieties, with the exception of Quechuan items in Bertonio's Aymara dictionary), partially shared (attested in at least one of the other family's varieties but not meeting the empirical thresholds for reconstruction), and shared (reconstructible in both proto-languages). These categories are presented in table 3 . Of the 566 Proto-Quechua $(b)$ and 496 Proto-Aymara $(c)$ lexical items-a total of $1,062-144$ were shared in both proto-languages $(d)$, leaving 918 distinct items (a). These correspond to the 918 rows given in Appendix A (available online only). Of the 566 Proto-Quechua items, 225 were unattested in any Aymaran source (other than Bertonio's dictionary) $(g)$, 197 were partially shared $(e)$, and 144 were fully shared $(d)$. Of the 496 Proto-Aymara items $(c), 231$ were unattested in any Quechua source $(h), 121$ were partially shared $(f)$, and 144 were fully shared $(d)$. This presentation of the data leaves out 5,867 of the 6,785 sets $(86.5 \%)$ that did not meet the thresholds for reconstruction in either proto-language.

Items were categorized as shared only if they are identical or nearly identical in each proto-language (for instance, Proto-Quechua *čaKwa 'fish' and 
TABLE 3

Shared, Partially Shared, and Non-Shared Lexical Items

(a) Total reconstructed roots: 918

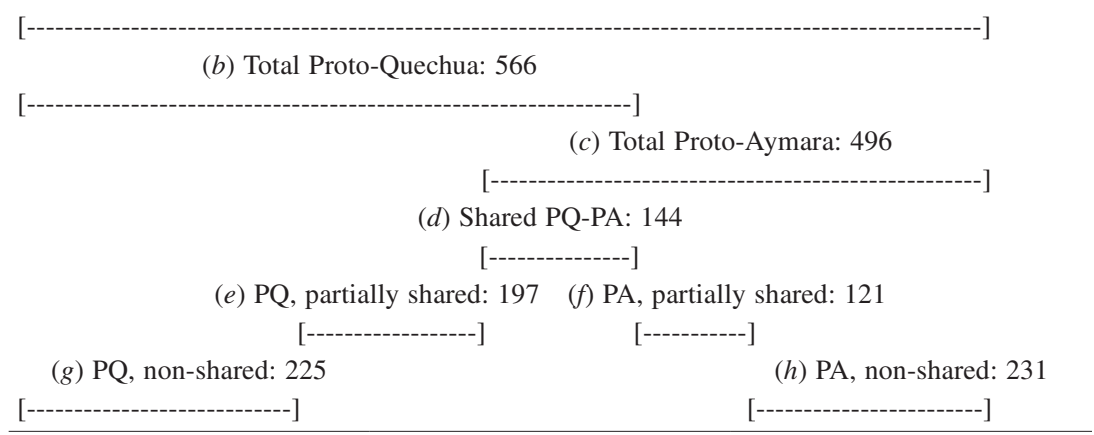

Proto-Aymara *čaאwa 'fish', and others in tables 1 and 2) and are therefore obviously attributable to borrowing. Items were considered nearly identical if they exhibited known sound correspondences, even if it is not clear how they came to be shared (e.g., in Proto-Quechua katşi 'salt' and Central Aymaran kati $i$ 'salt', where Central Aymaran usually maintains /tş/) (see Cerrón-Palomino 2000:136; Torero 2002:150). By this criterion, following Torero (2002:150), I do not count as shared the smaller number of items that bear suggestive formal and semantic resemblances between the two proto-languages but lie outside of known correspondence patterns (see Cerrón-Palomino 2000:31112). These include, among others, Proto-Quechua *katsa- 'to send, release' and Proto-Aymara *khita- 'to send'; Proto-Quechua *puka 'red, colored' and Proto-Aymara *čupika *čukipa 'red'; Proto-Quechua *haya- 'spicy, to be spicy' and Proto-Aymara *haru 'spicy, bitter, sour'; Proto-Quechua *ñuqa 'I' and Proto-Aymara *naya 'I'; Proto-Quechua *qam 'you' and Proto-Aymara *huma 'you'; and Proto-Quechua *mušuq 'new' and Proto-Aymara *mačaqa 'new' (see also Cambpell 2005). Given that the great majority of roots borrowed during the initial convergence are identical or nearly identical in both proto-languages, these cannot be easily attributed to the same period of borrowing. Whether they are due to an even earlier stratum of contact, a shared genetic inheritance, or mere coincidence is an empirical question that has yet to be addressed (Campbell 1995; Cerrón-Palomino 2000:310).

The shared categories $(d)-(f)$ in table 3 can be interpreted in terms of a rough relative chronology of borrowing between the Quechuan and Aymaran languages. The lexical items in $(d)$, those that can be reconstructed in both Proto-Quechua and Proto-Aymara, were most likely borrowed during the period of initial convergence. The items that can be reconstructed in only one proto-language but are attested in the other family-those in $(e)$ and 
(f) - may be attributable to the period of local convergence after the formation of the Quechuan and Aymaran families; however, this category surely also includes a number of loans from the period of initial convergence that failed to meet the thresholds for reconstruction in both families, either because they subsequently disappeared from the attested varieties or because they simply are not documented in my sources.

Clearly, the non-shared items in categories $(g)$ and $(h)$ can be attributed to the pre-proto-languages with the highest degree of confidence (note that these are indicated in boldface type in Appendix A [available online only]). For instance, it would be difficult to formulate a more compelling explanation than cognacy for a lexical root that exists in the two widely separated branches of the Aymaran family, exhibits the regular sound correspondences that emerged during the development of the Aymaran languages, and is unattested in any of the Quechuan languages that separate and surround them. My method assumes, therefore, that these items provide the clearest perspective on the pre-proto-languages from which they descend, and they are the basis for the phonological analyses in 4.3.

4.3. Phonological patterns. Once I isolated the non-shared portions of each proto-language's reconstructed lexicons-that is, the 225 ProtoQuechua and 231 Proto-Aymara items that are most likely to descend from their respective pre-proto-languages, represented in categories $(g)$ and $(h)$ in table 3-I analyzed the phonological patterns that each sample exhibited. Following Adelaar's (1986) proposals, I also examined the distribution of the aspirated and glottalized stops and affricates, the phonotactic constraints on syllable codas, and the appearance of root-final consonants. The PreProto-Quechua and Proto-Quechua systems are essentially the same-at least at the time depth accessible through this method-so I do not discuss them here. But there are notable differences between Pre-Proto-Aymara and Proto-Aymara, some attributable to the great influx of Quechua borrowings between those periods, that bear some mention. In particular, after briefly characterizing the Pre-Proto-Aymara phonemic inventory, I discuss in greater detail the glottal fricative $*^{*}$ (and its relation to the glides ${ }^{*} \mathrm{~W}$ and $* y$ ), glottalization and aspiration, and the appearance of consonants in syllable codas.

The phonology of Pre-Proto-Aymara is similar in most respects to the Proto-Aymara system reconstructed by Cerrón-Palomino (2000:118). Like Proto-Aymara and Proto-Quechua, Pre-Proto-Aymara had three vowels (*a, $\left.* \mathrm{i},{ }^{*} \mathrm{u}\right)$. There were voiceless stops at the labial, alveolar, velar, and uvular places of articulation ( $\left.{ }^{*} \mathrm{p},{ }^{*} \mathrm{t},{ }^{*} \mathrm{k},{ }^{*} \mathrm{q}\right)$ and voiceless alveo-palatal and retroflex affricates $(* \check{c}, *$ ts) . The Pre-Proto-Aymara stops may also have exhibited the same aspirated-glottalized-plain distinction that we find in Proto-Aymara and some Southern Quechuan varieties, and affricates were also glottalized, 
though there is little evidence of aspirated affricates. However, despite the clear presence of aspiration and glottalization at the Proto-Aymara stage, there is reason to question their status much further back in the Aymaran lineage (see 4.3.2 below). Pre-Proto-Aymara had an alveolar (*s) and a palatal (*š) sibilant; a bilabial, alveolar, and palatalized nasal ( ${ }^{*} \mathrm{~m},{ }^{*} \mathrm{n}$, and ${ }^{*} \mathrm{n}$, represented in this paper with the more common $\tilde{n}$ symbol), and possibly a relatively rare velar nasal *n (Adelaar 1996, Cerrón-Palomino 2000:155, and Torero 2002:115-16); lateral approximants $\left(*_{1}\right.$ and $\left.*_{K}\right)$, though $*_{K}$ is rather rare root-initially; a rhotic $*_{r}$ that does not appear root-initially; a labio-velar and a palatal approximant $\left({ }^{*} \mathrm{w}\right.$ and $\left.* \mathrm{y}\right)$; and a voiceless glottal fricative $*_{\mathrm{h}}$. But while this inventory is nearly identical in both Proto-Aymara and Pre-ProtoAymara, the distribution of some of the consonants in the two stages of the language is rather different.

4.3.1. Pre-Proto-Aymara $* \mathbf{h}$. One feature in particular that becomes clear about Pre-Proto-Aymara once the likely Quechuan loans are removed is the high frequency of lexical roots beginning in vowels (24.7\%) and in the voiceless glottal fricative *h (17.3\%) — together, nearly half of the sample. ${ }^{9}$ An abundance of minimal pairs (e.g., *aru- 'language, to speak' and *haru 'spicy, bitter, sour'; *iwa- 'to carry straw' and *hiwa- 'to die'; and *uma- 'water, to drink' and *huma 'you') demonstrates the importance of the *h- $\emptyset$ contrast in Pre-Proto-Aymara. However, *h is the only Pre-Proto-Aymara consonant that appears almost exclusively in root-initial position. ${ }^{10}$ The $*$ h- $\emptyset$ distinction, by contrast, apparently played a weaker role in Pre-Proto-Quechua: only $18.7 \%$ of the non-shared Proto-Quechua lexical roots in my sample begin in vowels, and only $3.6 \%$ begin in $*$ h, giving us few minimal pairs. ${ }^{11}$ Another important

$9 / \mathrm{h} /$ exhibits a curious correspondence in relation to aspiration. In Central Aymaran, there are many aspirated roots beginning in vowels (e.g., $a t^{h} a$ 'seed', $i k^{h} a$ - 'to herd', $u q^{h} u$ 'mud, swamp') but few beginning in /h/ (cf. hank ${ }^{h} a$ 'baggy, wide'); conversely, in Southern Aymaran, there are aspirated roots beginning in $/ \mathrm{h} /\left(h a t^{h} a, h i k^{h} a-, h u q^{h} u\right.$, of the same meanings as above) but few beginning in vowels (cf. $u r k^{h} u$ 'female garment'). Either Central Aymaran lost /h/ in aspirated roots, Southern Aymara gained it, or both. Absent further evidence, it is unclear whether *h should be reconstructed for these aspirated cognates (Landerman 1994:352), except when a lexical item exhibits variation in this respect within a particular branch (Cerrón-Palomino 2000:151). For cases in which it is impossible to tell whether a lexical item had *h or not, *h is indicated in parentheses. Note that such cases are counted as *h-initial in these tallies.

${ }^{10}$ The two exceptions in my data are *muhu 'seed' and *wihira 'drool, saliva'. However, both of these bear signs of Quechuan provenance: *muhu 'seed' resembles Proto-Quechua *muru 'seed, pit', and the initial /w/ of *wihira is found almost exclusively among Quechuan loans in Proto-Aymara (see 4.4). These items were not assigned a provenance in Appendix A, given their historically enigmatic character.

${ }^{11}$ The few roots that do begin in *h often manifest inconsistently across the Quechuan varieties. Note, however, that / $\mathrm{h} /$ became important later in many Southern varieties of Quechua as a prothetic feature of glottalized vowel-initial roots (Mannheim, n.d.), and in some Quechua I varieties following an $* \mathrm{~s}>* \mathrm{~h}$ merger. 
pattern in the non-shared Proto-Aymara lexicon is that $*_{\mathrm{y}}$ and $*_{\mathrm{W}}$ are all but absent root-initially but appear frequently in other positions. This pattern is obscured in Proto-Aymara and in the modern Aymaran languages by the large number of Quechua loans beginning in / $/ \mathrm{l}$ and /w/ -indeed, nearly all of the Proto-Aymara roots beginning in $*_{\mathrm{y}}$ and ${ }^{*} \mathrm{w}$ are found in the portion of the lexicon shared with Quechuan languages and likely originated there (see Appendix A [available online only]). This only becomes visible once the probable Quechuan loans are removed.

These consonants, therefore, are in complementary distribution: *h appears in root-initial position but rarely elsewhere, while $*_{\mathrm{w}}$ and $*_{\mathrm{y}}$ appear regularly everywhere except root-initially. This complementary distribution, along with the fact that $*$ h appears initially almost three times more frequently in my data set $(17.3 \%$ of roots) than the second most common initial consonant (*ts', $6.1 \%$ of roots), suggests that $*_{\mathrm{y}}$ and $*_{\mathrm{w}}$ were likely subject to a consonant merger $\left(*_{\mathrm{w}}, *^{\mathrm{y}}>*_{\mathrm{h}} / \#_{-}\right)$earlier in the history of Pre-Proto-Aymara. A further piece of evidence supporting this hypothesis is that a number of modern Aymaran lexical items are attested inconsistently with initial $/ \mathrm{h} /$ and either /w/ or /y/ (Cerrón-Palomino 2000:165-66). This variation occurs within each branch of the language family, as in Southern Aymaran $h a q^{h} a \sim y a q^{h} a$ 'other, different', $h a k^{h} u \sim w a k^{h} u$ 'to count', hip $i \kappa a \sim$ wiph $i \kappa a$ 'intestines', and $h i s k^{h} u \sim w i s k^{h} u$ 'sandal', ${ }^{12}$ as well as between the branches of the family, as in Central Aymaran wari- and Southern Aymaran hari- ari- 'to debut, use something for the first time' (note also ari- of the same meaning in Ancash Quechua and Cuzco Quechua). Furthermore, there are some distinct ProtoAymara roots beginning with these consonants that appear to be cognates (e.g., *wala- 'to run' and *hala- 'to fall, fly, run, go out'). ${ }^{13}$ This correspondence also appears in apparent Quechuan loans (e.g., Southern Aymaran hisk'aču wisk'ača wisk'aču 'rodent species', hič $u \sim$ wič $u \sim i \check{c}^{h} u$ 'straw, hay'). These cases indicate that there was some inconsistency in the application of this sound change, perhaps in the service of avoiding homophony (e.g., Southern Aymaran $h a k^{h} u$ 'to breathe, sigh' and $h a k^{h} u \sim w a k^{h} u$ 'to count'). Note that

12 It is probably significant that many of these roots that contain stops and affricates are aspirated, a feature that is closely associated-though in ways that are not entirely clear-with $/ \mathrm{h} /$.

13 This alternation is also found in some varieties of Quechua. For instance, Pan-Quechuan yayku- 'to enter' is attested as hayku- in Cuzco Quechua, and yarawi-, harawi-, and arawi- 'a type of song or poem, to perform song or poem' all appear sporadically across the Quechuan family. Therefore, this type of sound change may be a broader areal phenomenon. Note that there are also occasional /y/-/w/ correspondences between the two Aymaran branches, as in the Southern items č'uya 'clean, clear, pure (liquids)' and t'iyu 'sand' and their Central cognates č'uwa and t'iwu (Cerrón-Palomino 2000:161). In some cases, this /y/-/w/ correspondence obtains in probable Quechuan loans, as in Southern Aymaran wampu- yampu- 'raft; to float, navigate boat, swim' (from Proto-Quechua *wampu- of the same meaning). Rodolfo Cerrón-Palomino (personal communication) also reports a $-w i>-w>-y$ change at the end of some toponyms. 
this merger may be related to the later velarization of intervocalic *y (and to a lesser extent, ${ }^{*} \mathrm{w}$ ) in Central Aymaran (Cerrón-Palomino 2000:160-66), which suggests a more widespread and long-term instability of $*_{\mathrm{y}}$ and ${ }^{*} \mathrm{w}$ in the development of the Aymaran languages (see also Landerman 1998:37).

Because this change makes it impossible to know what the original values of root-initial *h in specific lexical roots might have been before the merger, it is not certain whether there was an $/ \mathrm{h} /$ at all earlier in the history of the language; but given the consonant's prominence in Pre-Proto-Aymara, it seems likely. Efforts to identify deeper genetic relations for Pre-Proto-Aymara should consider that any initial $*$ h may have originally been $* \mathrm{y},{ }^{*} \mathrm{w}$, or $*$ h. Further documentation of Aymaran languages will surely turn up other cases of initial $/ \mathrm{h} / \sim / \mathrm{w} /$ and $/ \mathrm{h} / \sim / \mathrm{y} /$ variation. It is also interesting to note that if this interpretation is correct, the phonology of Pre-Proto-Aymara would have been more Quechua-like before this merger than after it.

4.3.2. Glottalization and aspiration. The historical status of glottalization and aspiration in the Quechuan and Aymaran languages, and the implications of that history for the relationships between the languages, is one of the most complex and thoroughly debated issues in Andean linguistics (Adelaar 1986:385-89; Adelaar and Muysken 2004:195; Campbell 1995, 1997:275-82; Cerrón-Palomino 1987:118-21, 2000:316-24; Hardman 1985; Landerman 1994; Mannheim 1985, 1986, 1991:177-207; Orr and Longacre 1968; Parker 1963:248-49; Stark 1975; Torero 1964:463-64, 2002:151-60). It is clear that aspiration and glottalization existed at the moment of the Central-Southern split in the Aymaran family; however, as is discussed below, there may be reason to doubt their status earlier in Pre-Proto-Aymara, before the period of initial convergence with Pre-Proto-Quechua in central Peru. This section briefly introduces glottalization and aspiration as they relate to the QuechuaAymara relationship and then discusses these features in Proto-Aymara and Pre-Proto-Aymara. The section concludes with a discussion of the evidence for their presence further back in the Aymaran lineage and the potential implications of this analysis for the linguistic prehistory of the Central Andes.

4.3.2.1. Glottalization, aspiration, and the Quechua-Aymara relationship. The question of whether glottalization and aspiration existed in both Proto-Quechua and Proto-Aymara, or whether they existed only in ProtoAymara and were later borrowed into some Quechuan varieties as a result of local contact with Aymaran languages, has long been at the center of the debate over a putative Quechuan-Aymaran (or Quechumaran) genetic grouping. The reconstruction of these features in both Proto-Aymara and Proto-Quechua has been part of an argument for common descent (Orr and Longacre 1968), while their presence in Proto-Aymara and absence in Proto-Quechua has been advanced in support of a hypothesis of areal convergence. When consensus eventually formed around the latter position (e.g., Cerrón-Palomino 1987; 
Mannheim 1991), the question of a genetic relationship_ — and attempts to disentangle and periodize the contact history-were mostly dropped. However, given the susceptibility of glottalization and aspiration to areal diffusion, this paper takes the position that the status of these features must be disengaged from the Quechumaran question (Adelaar 1986) if it is to be adequately addressed.

Most Andeanists today believe that glottalization and aspiration existed in Proto-Aymara, but not in Proto-Quechua, and that these features were overlaid onto the existing lexicon of some Quechua IIC varieties, alongside some Aymaran borrowings, as a result of relatively recent localized contact with Southern Aymaran (note that some Ecuadorian varieties also took on aspiration as a later contact effect) (see Torero 1984). Intriguingly, in many cases these features were transferred from Southern Aymaran to Quechua IIC varieties in the very lexical items that were already shared at the level of the two proto-languages (e.g., the extension of glottalization from Southern Aymara $\check{c}$ ' $a \chi \check{c}$ ' $u$ - 'to spray, sprinkle' to Cuzco Quechua $\check{c}^{\prime} a q \check{c} u$ - of the same meaning, a root that had been borrowed much earlier from Pre-Proto-Quechua root *čaqču- into Proto-Aymara as *č'aqču-). In cases like these, glottalization and aspiration are not helpful as indicators of provenance. The complexity of this process has represented a difficult puzzle in Andean historical linguistics but it is somewhat easier to understand when one imagines a society of deeply bilingual people in Bolivia and southern Peru using glottalization and aspiration in many transparently identical or nearly identical shared lexical items in both of their languages - that is, in what were likely perceived by speakers as the same roots, regardless of which language they were used in. At that point, the features were propagated through both the Southern Quechuan and the Southern Aymaran lexicons by a number of semiotic and phonetic processes (Mannheim and Newfield 1982; Mannheim 1991) that were also common to both languages (Adelaar 1986:390-91). The distribution of glottalization and aspiration is rather inconsistent within the Aymaran and Southern Quechuan lexicons today, though there is a set of lexical items that varies little from one variety to the next (Adelaar 1986:388; CerrónPalomino 2000:319). Notably, there may be more consistency in glottalization and aspiration between Cuzco Quechua and Southern Aymaran, in the items shared by those languages, than in the items shared by Southern Aymaran and Central Aymaran. This suggests that these features are strongly subject to areal influence and that they are quite unstable over time.

4.3.2.2. Glottalization and aspiration in Proto-Aymara. Glottalization and aspiration clearly existed in Proto-Aymara, as can be seen in the large number of Central and Southern Aymaran cognates bearing these features, both shared and non-shared. However, their diachronic instability presents a number of difficulties for interpreting their history. For instance, while aspiration and glottalization are consistent among many Central and Southern Aymaran cognates (e.g., $k^{h}$ ari- : $k^{h}$ ari- 'to cut (e.g., meat), skin', $a t^{h} a: h a t^{h} a$ 
'seed', ts'ina : ć'ina 'butt', hunts'u: hunt'u 'hot'), there are also many cognates that do not match in this respect (e.g., quma- : $q^{h} u m a$ - 'to hug, brood', $q^{h}$ ints $_{e^{h}} a$ : qinča 'corral, fenced enclosure', ča $a$ a- : č 'aরa- 'to splash, sprinkle'). While the former set can be straightforwardly reconstructed as reflexes of aspirated and glottalized Proto-Aymara roots, the latter set, in which Central and Southern Aymaran cognates do not agree with respect to their aspiration and glottalization status, presents a problem. For each such mismatching cognate set, there are two possibilities: first, that the Proto-Aymara root had the feature in question but that it was lost in one branch; or second, that the feature did not exist in the Proto-Aymara lexical item and was later applied to its reflex in one of the two branches. Some such innovations are clearly the product of iconicity or other later phonological developments, but in most cases there is no obvious reason to favor one explanation over the other. Given the instability of glottalization and aspiration, it is likely that both have taken place to some degree.

Cerrón-Palomino (2000) reconstructs aspiration and glottalization for mismatching Aymaran cognates that cannot be otherwise explained, on the grounds that-in the absence of other evidence-loss is a more parsimonious explanation than innovation. This is a reasonable approach to a difficult situation, and I have followed Cerrón-Palomino's analysis here, with two minor modifications. First, there are very few roots in either branch with aspirated affricates (see Torero 2002:113), and only a couple of these exhibit aspiration in cognates from both branches. Note also that there are no Aymaran grammatical morphemes with aspirated affricates. This stands in stark contrast to the aspirated and glottalized stops, which are much more numerous, correspond frequently in both branches, and appear in grammatical morphemes. So while the lack of aspiration in affricates might constitute a curious asymmetry in the consonant inventory, evidence of their existence is simply too thin to reconstruct them with any confidence in Proto-Aymara (see table 4).

Second, in cases of cognates with mismatching aspiration and glottalization status, Central Aymaran is almost always the branch lacking the feature in question-except in the case of $/ \mathrm{q}^{\mathrm{h}} /$. Compare, for instance, Central Aymaran $q^{h} i p u$ 'thorn, thorny plant', $q^{h} i \tilde{n} w a$ 'Polylepsis incana', $q^{h} u n q u r u$ 'knee', $q^{h} u r p a$ 'irrigation canal', and $q^{h}$ ints $^{h} a$ 'corral, fenced enclosure' with their Southern Aymaran cognates qipu 'thorn', qiñwa 'Polylepsis incana', qunqura qunquri qunquru 'knee', qurpa 'furrow, ditch, boundary', and qinča 'corral, fenced enclosure'. The aspiration of uvular stops also appears to have applied to etymologically glottalized roots (compare Central Aymaran $q^{h} a s p a-$ 'to singe, scrape surface', $q^{h}$ iri 'dandruff', and $q^{h}$ amya 'tasteless [food]' with Southern Aymaran cognates q'aspa- 'to singe, scrape surface', q'iri 'wound, scab, scale', and q'ayma 'tasteless [food]). ${ }^{14}$ Since $/ q^{\mathrm{h}} /$ is the only aspirated

${ }^{14}$ Note that each of these eight items is shared with at least one Quechuan variety, including Cuzco Quechua, and that Cuzco Quechua shares the Southern Aymaran aspiration/glottalization 
TABLE 4

Non-Shared Proto-Aymara Consonants as First Stop/Affricate

\begin{tabular}{|c|c|c|c|}
\hline & Plain & Glottalized & Aspirated \\
\hline \multicolumn{4}{|c|}{ (a) Stops } \\
\hline $\mathrm{p}$ & *puši 'four' & $\begin{array}{l}\text { *p'iya- 'hole, opening, } \\
\text { to cut an opening, clear } \\
\text { inflate' a path' }\end{array}$ & *p phusa- 'to blow, \\
\hline $\mathrm{t}$ & *turu 'blunt, rounded' & $\begin{array}{l}\text { *t'uru- 'to gnaw, chew, } \\
\text { crunch in teeth' }\end{array}$ & *at ${ }^{\text {ha }}$ 'seed' \\
\hline $\mathrm{k}$ & *kayu 'foot' & *k’awna ‘egg' & $\begin{array}{l}\text { *k ari- 'to cut } \\
\quad \text { (e.g., meat), skin' }\end{array}$ \\
\hline q & $\begin{array}{l}\text { *qisa 'hopeless, } \\
\text { abandoned, dejected' }\end{array}$ & *q'asa- 'to moan, yell' & *q $\mathrm{q}^{\mathrm{h}} \mathrm{K} \mathrm{a}$ 'ashes' \\
\hline \multicolumn{4}{|c|}{ (b) Affricates } \\
\hline$\check{c}$ & *čiñwi 'bat (animal)' & $\begin{array}{l}\text { *č'ama 'dark, darkness, } \\
\text { night, to become night, } \\
\text { close eyes, blink' }\end{array}$ & \\
\hline tş & *hatşa- 'to cry, moan' & *ts'iyara 'black' & \\
\hline
\end{tabular}

or glottalized consonant that regularly appears in Central Aymaran but not Southern Aymaran cognates, the Central Aymaran aspirated uvular stops that correspond to plain or glottalized uvular stops in Southern Aymaran are likely due to innovation in the former branch. Apart from these two minor points, I have followed Cerrón-Palomino's practice of reconstructing glottalization and aspiration in cases where these do not agree between Central and Southern Aymaran cognates. Note, however, that there are seven Proto-Aymara forms whose Central and Southern Aymaran reflexes inconsistently attest both aspiration and glottalization. It is impossible to know which (if either) of these is original, or if the variation existed in the proto-language, so for these both aspirated and glottalized forms are listed in my data (e.g., *k'uKu $\sim{ }^{*} \mathrm{k}^{\mathrm{h}} \mathrm{u} \mathrm{Ku}$ 'tree trunk, wood').

Before moving on, let me note two patterns within this inconsistency between the Central and Southern branches. First, glottalization appears to have been more stable than aspiration in the Aymaran languages: glottalization agrees in 98/132 (74.2\%) of cognates that descend from Proto-Aymara roots that I reconstructed with glottalization, while aspiration agrees in only $35 / 65$ (53.8\%) of cognates that descend from reconstructed aspirated roots. ${ }^{15}$ This

status of all eight. This suggests that these Central Aymaran items developed aspiration independently of the contact affecting Southern Quechua and Southern Aymara. However, one of these ( $q^{h} i p u$ 'thorn, thorny plant') is aspirated in Puno Quechua (Laime Ajacopa et al. 2007:95), where Southern Aymara is also spoken.

15 These figures omit the seven Proto-Aymara forms whose Central and Southern Aymaran reflexes inconsistently attest both aspiration and glottalization. 
suggests that both are quite diachronically unstable, but that glottalization is more stable than aspiration. Second (as mentioned above), in cases of inconsistency between Central and Southern Aymaran, it is usually the Central branch that lacks the feature in question: in the 34 cases of disparity in glottalization, only 7 (20.6\%) are found in Central but not Southern Aymaran cognates; and of the 30 cases of disparity in aspiration among roots that can be reconstructed with aspiration, only $4(13.3 \%)$ are found in Central but not Southern Aymaran cognates. In other words, with a few exceptions, the portions of the Central Aymaran lexicon with glottalization and aspiration are largely subsets of the Southern Aymaran lexicon exhibiting those features. One possible explanation is that Central Aymaran lost some of its glottalization and aspiration as a result of being surrounded by central Peruvian languages (Quechuan, and likely others) that lack these features, or this may have just been an internal development.

There were a number of phonotactic constraints on glottalization and aspiration in Proto-Aymara, which are similar in most respects to those found in the relevant Southern Quechuan varieties. These constraints vary by family - for instance, in Aymaran languages the features appear in both suffixes and lexical roots, while in most Southern Quechuan varieties they appear only in lexical roots-but for the most part, the constraints on their distribution in lexical roots are similar (note that I do not address here the morphophonemic effects that take place outside of lexical roots in Aymaran languages, which are much more complex) (see, for instance, Hardman 1986). In both families, aspiration and glottalization can only appear on the first syllable-initial stop or affricate in the root, regardless of where it falls in the word (e.g., Proto-Aymara *harap ${ }^{\mathrm{hi}}$ 'rib, ribs'; Cuzco Quechua warak'a 'sling, slingshot'). In Central Aymaran, as in Southern Quechua, only one aspirated or glottalized consonant can appear in a root (save for a handful of exceptions); Southern Aymaran appears to have elaborated this basic system in some cases by extending glottalization and aspiration to a second (often identical) consonant in a lexical root (Adelaar 1986:388; Landerman 1994, 1998), as in t'ant' $a$ 'bread', $k^{h} a n k^{h} a$ 'dirty, mangy', and $p^{h} u q^{h} a$ 'full'. This is particularly common after nasal and fricative codas (Coler 2014:40). In a few Southern Aymaran roots, the aspiration of a second stop or affricate in a lexical root is allowed when the first stop or affricate is glottalized (e.g., č ' $a r k^{h} i$ 'jerky', $k^{\prime} a p^{h} a$ - 'fragile, to break', $t^{\prime}{ }^{\prime m}{ }^{h} u$ - 'to pin up, roll up fabric'). Such elaborations of the basic pattern are not unknown in Central

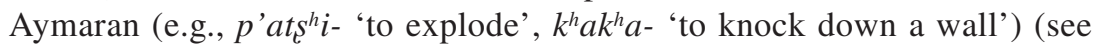
Torero 2002:151), but they are much rarer and are likely innovations, and indeed none match their Southern Aymaran cognates. There is a good deal of inconsistency with regard to these restrictions, and colonial sources show some earlier forms that violate the first syllable-initial stop/affricate rule 
(Adelaar and Muysken 2004:199, n. 20). But in general, aspiration and glottalization in Proto-Aymara lexical roots appear to have been mostly limited to the first syllable-initial stop or affricate.

4.3.2.3. Glottalization and aspiration in the non-shared Proto-Aymara lexicon. In the non-shared portion of the Proto-Aymara lexicon-that is, the portion of the lexicon that most likely descends from Pre-Proto-Aymara-the situation is a bit different. Table 4 illustrates how the stops and affricates intersect with the three-way plain/glottalized/aspirated distinction. As mentioned above, these features always appear on the first possible consonant in the root-that is, the first syllable-initial stop or affricate-regardless of where that consonant is in the root. In table 4, (a) shows that stops at all four points of articulation $(* \mathrm{p}, * \mathrm{t}, * \mathrm{k}, * \mathrm{q})$ exhibit a clear three-way distinction (though glottalized bilabial stops are rarer). However, the application of aspiration and glottalization to the affricates $*_{c}$ and *ts $(b)$ is more uneven. First, as mentioned above, there is little evidence of aspiration in either alveo-palatal or retroflex affricates. Second, retroflex affricates that are the first syllable-initial stop or affricate in a root (i.e., in the position eligible for glottalization) are almost always glottalized. There are a few exceptions, such as plain *hatsa- 'to cry, moan' listed in $(b)$; however, glottalized forms such as *ts'aka 'chest', *(h)unts'u 'hot', *tşaqa- 'to split apart', *tş'ina 'butt', and *ats'i- 'to dig, scratch' are much more common.

The predominance of *ts' suggests that *ts may have undergone a fairly regular process of glottalization in the applicable context in the Pre-ProtoAymara stage; indeed, this would explain why *ts' is by far the most frequent initial consonant in the non-shared Proto-Aymara lexicon. Another interesting pattern bears mentioning: while plain $*_{c}$ is often the first stop/affricate in a root, as in *čika- 'knot, to tie, thread' *činqi 'vagina', *ačuma 'cactus species', *hanči 'meat, flesh, skin', it is never the second (at least in the nonshared lexicon). Accounting for these patterns historically is difficult, but it is clear that (1) the history of the affricates is closely connected to the history of glottalization and (2) stops and affricates may have behaved differently in Pre-Proto-Aymara with respect to glottalization and aspiration. There are some differences in the distribution of aspiration and glottalization between the shared and non-shared portions of the Proto-Aymara lexicon (for instance, there are a handful of non-glottalized retroflex aspirates in the first eligible position of shared roots), but these are relatively minor.

4.3.2.4. Uncertainties regarding glottalization and aspiration before the initial convergence. The account given so far is useful for understanding glottalization and aspiration since, and immediately before, the earliest reconstructible stage of Proto-Aymara. However, there are reasons to be careful about assuming that glottalization and aspiration existed much further back in the Aymaran lineage and, in particular, before the initial convergence 
with Quechua. This section begins by outlining some of the reasons for this uncertainty and then proposes a method for testing whether $(a)$ glottalization and aspiration existed in the Aymaran lineage before the initial convergence with Quechua or $(b)$ they were overlaid onto the Aymaran lexicon after the initial convergence. The data do not offer a definitive answer to this question, but (at least in the case of glottalization) they do appear to support the latter scenario. If in fact the Aymaran lineage took on these features after the initial convergence, it then becomes necessary to consider the ethnohistorical question of how, and where, this might have happened.

It may not be immediately apparent why the antiquity of glottalization and aspiration in the Aymaran lineage should be subject to doubt. However, there are a few inconsistencies in the story thus far that should give us pause. First, consider the following contradiction: if $(a)$ the grammatical structure and perhaps the phonology of Pre-Proto-Quechua were remodeled on the Pre-Proto-Aymaran template, $(b)$ Pre-Proto-Aymara had glottalization and aspiration at that point, and $(c)$ glottalization and aspiration have repeatedly proved to be highly prone to diffusion, then it is unclear why Pre-ProtoQuechua would not have taken on those features during the initial convergence. Second, if Pre-Proto-Aymara had these highly diffusible features in central Peru, then it remains to be explained why there is no trace of them in the Quechuan languages of that region (despite other types of Aymaran influence, for instance, on Pacaraos Quechua and Huanca Quechua). Indeed, these features are mostly found much further south, around Lake Titicaca, where they are shared among a number of languages across genetic groupings (e.g., Southern Quechua, Uru-Chipaya, Leko, Kallawaya, and possibly Puquina) (see Michael, Chang, and Stark 2014). These contradictions leave us with two possible hypotheses: (1) that Pre-Proto-Aymara had aspiration and glottalization before the initial convergence, but that these were not among the elements that diffused into Pre-Proto-Quechua; or (2) that aspiration and glottalization were first overlaid onto the Aymaran lexicon after its initial period of convergence with Pre-Proto-Quechua, but some time before the development of the clade descending from what we call Proto-Aymara (since these features exist in all of the attested Aymaran languages).

My data set offers a way to test these hypotheses. If Pre-Proto-Aymara had aspiration and glottalization before the initial convergence with PreProto-Quechua (Hypothesis 1), we would expect a substantially higher proportion of these features in the native, non-shared portion of the ProtoAymara lexicon than in the shared portion. After all, the shared portion (as shown in $\mathbf{4 . 4}$ below) consists primarily of loans from Pre-Proto-Quechua, which lacked these features. If, on the other hand, aspiration and glottalization were overlaid onto the Aymaran lexicon after the Quechuan loans had been integrated (Hypothesis 2), we would expect them to be more evenly 
TABLE 5

Glottalized, Aspirated, and Plain Proto-Aymara Roots

\begin{tabular}{lcc}
\hline \hline & Non-Shared PA & Shared PQ/PA \\
\hline Glottalized & $63(27.3 \%)$ & $30(20.8 \%)$ \\
Aspirated & $39(16.9 \%)$ & $11(7.6 \%)$ \\
Plain & $129(55.8 \%)$ & $103(71.5 \%)$ \\
Total & $231(100 \%)$ & $144(100 \%)$ \\
\hline
\end{tabular}

distributed across the non-shared and shared lexical items. These results are listed in table 5.16

In my data set, roots with glottalized consonants appear in $27.3 \%$ of the non-shared Proto-Aymara lexicon and in $20.8 \%$ of the lexicon shared with Proto-Quechua; however, this difference is not statistically significant $(p=$ .16). This lack of a statistically demonstrable disparity supports the scenario described in Hypothesis 2, in which glottalization would have been overlaid onto the Aymaran lexicon after the incorporation of the Quechuan loans. However, roots with aspirated consonants appear in $16.9 \%$ of roots in the non-shared Proto-Aymara lexicon and in $7.6 \%$ of roots in the lexicon shared with Proto-Quechua, a difference that is significant at the .05 threshold $(p$ $=.01$ ). This finding supports Hypothesis 1: that aspiration existed in PreProto-Aymara prior to, or at least at the moment of, the initial convergence with Quechua. It is thus possible that glottalization and aspiration entered the Aymaran lineage at different moments and in different places-indeed, these features often move independently in the languages of the Americas.

However, this finding is not entirely satisfying: if aspiration were widespread in Pre-Proto-Aymara, then it is not clear why the disparity in aspiration between the non-shared roots and the shared roots would be so slight. Since the shared lexicon is mostly composed of Quechuan roots (see 4.4) that did not have aspiration, we would expect to see far fewer aspirates in that domain of the lexicon, particularly so soon after the initial convergence. A possible explanation might be that if aspiration indeed existed in PreProto-Aymara, then it may have been a recent development that was still underway at the moment of the initial convergence. It is possible, of course, that both aspiration and glottalization existed in Pre-Proto-Aymara, and that they were simply propagated so thoroughly, and so quickly, through the borrowed Quechuan lexicon that there remained little disparity even at this early

${ }^{16}$ As discussed above, aspiration and glottalization both appear in the modern reflexes of seven of the 496 reconstructed Proto-Aymara items, making it impossible to tell whether the proto-form was aspirated or glottalized. Two of these items appear in the shared Proto-Quechua/ Proto-Aymara data presented in table 5 , and each was counted as 0.5 glottalized and 0.5 aspirated. 
moment. However, this would be a rather dramatic and rapid transformation. Furthermore, we might expect traces of it in the form of glottalization and aspiration serving iconic functions within networks of semantically related roots (as in Southern Quechua more recently) (see Mannheim 1986, 1991) that span the shared and non-shared lexicons; however, we do not see this. In any case, these findings are not in themselves enough evidence to draw any firm conclusions on the matter but only to draw attention to this uncertainty and urge caution in interpreting the prehistory of glottalization and aspiration in the Central Andes. Efforts to identify deeper genetic relations for Pre-Proto-Aymara should consider the possibility that glottalization did not originally exist in that lineage, and that aspiration may have played a more limited function if it existed at all.

These patterns raise a number of historical problems. For instance, if we entertain a scenario in which Pre-Proto-Aymara did not begin with glottalization and possibly aspiration, then it is necessary to ask when and where they appeared in the Aymaran lineage. Since the areal distribution of these features is concentrated in southern Peru and the Altiplano, one hypothesis might be that Aymaran acquired glottalization only after moving south from central Peru. In this scenario, Central Aymaran would have been a back-migration from further south. This would remain, of course, a matter of speculation absent further evidence, but no more so than its alternatives, which would have to account for these patterns and for the problems outlined above.

\subsubsection{Root-internal non-resonant codas and root-final conso-}

nants. Adelaar (1986) observed that items with root-internal syllable codas were more common in the pan-Quechuan lexicon than in the pan-Aymaran lexicon and that root-internal non-resonant ${ }^{17}$ codas seldom occurred in the pan-Aymaran lexicon but were common in the pan-Quechuan lexicon (e.g., the non-shared Proto-Quechua items * Kaq.wa- 'to lick', *šik.wa- 'to broadcast seeds', *tap.ši- 'to shake up, shake out'). The data comparing these features in the non-shared Proto-Aymara and Proto-Quechua lexicons are presented in table 6.

My sample confirms Adelaar's observation: as shown in part (a) of table 6, 44.0\% of Pre-Proto-Quechua lexical roots have internal syllable codas, but only $20.8 \%$ of Pre-Proto-Aymara lexical roots have them. This disparity is highly statistically significant $(p<.001)$. As shown in $(b)$, of the 99 Pre-ProtoQuechua root-internal syllable codas mentioned in $(a)$, around half $(50.5 \%)$ are resonants and half (49.5\%) are non-resonants. On the other hand, of the 48 Pre-Proto-Aymara first-syllable codas, only eight (16.7\%) are non-resonants. ${ }^{18}$

${ }^{17}$ Following Adelaar (1986:384), the term "resonant" is used to describe the nasal and approximant consonants ( $m, n, n, \eta, y, w, r, l, \kappa)$, which comprise the voiced consonants in both language families.

${ }^{18}$ The eight non-shared roots are *išk'a- 'to urinate', *išt'a- 'to close', *t'apra 'wool', *tuksa'to stink', *ts'ikma 'pillow, head rest', *muqsa 'sweet', *tşaqmi- 'sad, angry, bothered, to bother, 
TABLE 6

Root-Internal Codas in Non-Shared Proto-Aymara and Proto-Quechua Roots

\begin{tabular}{lrr}
\hline \hline & PA Non-shared & PQ Non-shared \\
\hline$(a)$ & $48(20.8 \%)$ & \\
Roots with internal codas & $183(79.2 \%)$ & $126(56.0 \%)$ \\
Roots without internal codas & $231(100 \%)$ & $225(100 \%)$ \\
Total roots & & \\
& & \\
$(b)$ & $40(83.3 \%)$ & $50(50.5 \%)$ \\
Resonant root-internal codas & $8(16.7 \%)$ & $49(49.5 \%)$ \\
Non-resonant root-internal codas & $48(100 \%)$ & $99(100 \%)$ \\
Total roots with internal codas & & \\
\hline
\end{tabular}

This difference between non-resonant first-syllable codas in Pre-Proto-Quechua and Pre-Proto-Aymara is also highly statistically significant $(p<.001)$. From these patterns, we can conclude that root-internal syllable codas were more common in Pre-Proto-Quechua lexical roots than in Pre-Proto-Aymara lexical roots, and that Pre-Proto-Aymara likely only had resonant codas. While the overall disparity in syllable codas does not constitute a diagnostic for determining the directionality of borrowing of shared Proto-Quechua and Proto-Aymara roots, the disparity in types of codas allows us to attribute shared items with non-resonant codas to Pre-Proto-Quechua.

Similarly, Adelaar observes that while Pre-Proto-Aymara roots never end in consonants, Pre-Proto-Quechua roots often do: in my sample, 23.5\% (24/102) of Pre-Proto-Quechua non-verbs end in consonants (verb roots always end in vowels). Shared lexical items that exhibit this difference can be attributed to Pre-Proto-Quechua, since this is a natural modification to make in order to fit Quechua loans into Aymaran phonotactic constraints, but there would be no motivation for the loss of the final vowel if the roots had been borrowed from Pre-Proto-Aymara to Pre-Proto-Quechua. For example, compare Proto-Quechua *patşak 'hundred' and *kuntur 'condor' with Proto-Aymara *patsaka and *kunturi of the same meanings, as well as more recent Spanish loans such as tuktura 'doctor', from Spanish doctor (Adelaar 1986:384). ${ }^{19}$

annoy', and *yuqts'a 'daughter-in-law'. Some of these are likely explainable as undetected borrowings, perhaps of Quechua roots that subsequently disappeared in Quechua-for instance, *muqsa 'sweet' is reminiscent of Proto-Quechua *miški 'sweet'. Others are probably involved lexicalized suffixes. For instance, *išt'a- is likely bimorphemic (Cerrón-Palomino 2000:149), and *yuqts'a 'daughter-in-law' is clearly derived from *yuqa 'son'.

${ }^{19}$ On the other hand, Rodolfo Cerrón-Palomino (personal communication) points out that final vowels are sometimes deleted in Quechua, for instance, in some toponyms and in some word-final morphemes appearing after vowels (such as the genitive case marker $-p a>-p$ ). 
4.4. Sorting the shared lexicon. At this point, my method has generated 225 probable Pre-Proto-Quechua lexical items and 231 probable PreProto-Aymara lexical items. However, it is possible to go further and use the diagnostic phonological and phonotactic patterns identified in $\mathbf{4 . 3}$ to establish provenances for some of the shared and partially shared lexical items as well. For instance, *wiqru 'lame, with an injured foot, bowlegged, twisted' and *wakča 'poor, orphan' can be reconstructed in both Proto-Quechua and Proto-Aymara, but both their telltale initial $*_{\mathrm{w}}$ and non-resonant codas betray their origin in the Quechuan lineage. Universally shared roots with no diagnostic phonological features (e.g., *kuti 'time, occasion', *nina 'fire'), on the other hand, do not suggest a provenance. It is important to point out that there are no reliable positive indicators of Aymara origin, so I have not identified shared proto-forms originating in Pre-Proto-Aymara. One possible exception is initial *h, which is very widespread in Pre-ProtoAymara but rare in Pre-Proto-Quechua. It may be, therefore, that some *h-initial Proto-Quechua roots originate in Pre-Proto-Aymara, but this is uncertain.

In Appendix A (available online only), provenances are listed for 686 of the 918 reconstructed forms: 427 Quechuan and 259 Aymaran (indicated in Appendix A by Q and A, respectively). Provenances were proposed for items that met one or both of two criteria. First, items that could be reconstructed in one proto-language but were attested in one or zero varieties of the other language family were attributed to the former. Second, items containing phonological features diagnostic of Quechuan origin (non-resonants in syllable codas, word-final consonants, initial $*_{\mathrm{w}}$ or *y) were designated as Quechuan. This was applied to both the shared lexicon and the partially shared Aymaran and Quechuan lexicons. Lexical items that did not meet either of these criteria were not assigned a provenance. In a few cases, the two criteria mentioned above conflict—for instance, Proto-Aymara * Kiqwi 'phlegm, mucus, bodily fluid' and *šaqša 'ragged, frayed, tousled' each have a characteristically Quechuan non-resonant syllable coda but are only attested in one variety of Quechua (Cuzco). Such items are most likely Quechuan in origin but are simply unattested in other Quechuan varieties, so they are designated here as Quechuan. The handful of non-shared Proto-Aymara items with non-resonant syllable codas or initial *w and *y (e.g., *muqsa 'sweet' and *wala 'to run') were not assigned a provenance, given their historically enigmatic character.

According to my analysis, 42 of the 144 items shared by Proto-Quechua and Proto-Aymara can be designated as Quechuan on the basis of phonological criteria (those beginning in $*_{\mathrm{w}}$ or $* \mathrm{y}$ ) and/or phonotactic criteria (those with a root-internal non-resonant coda or a root-final coda). Of 121 partially shared Proto-Aymara items (that is, those that are also attested in at least one Quechuan source but which do not meet the standards for reconstruction in 
TABLE 7

Diagnostic Quechuan Features in the Non-Shared PQ and Shared Lexicons

\begin{tabular}{lcc}
\hline \hline & Non-shared PQ $(\mathrm{N}=225)$ & Shared PQ-PA (N = 144) \\
\hline *w-initial & $18(8.0 \%)$ & $17(11.8 \%)$ \\
*y-initial & $8(3.6 \%)$ & $5(3.5 \%)$ \\
& $49(21.8 \%)$ & $20(13.9 \%)$ \\
Root-internal non-resonant coda & $24(10.7 \%)$ & $5(3.5 \%)$ \\
Root-final coda &
\end{tabular}

Proto-Quechua), 22 can be identified as probable Quechuan loans by these diagnostic criteria. The remaining 102 of 144 items shared by Proto-Quechua and Proto-Aymara do not offer many hints regarding their origins; however, it is possible to draw some general conclusions about the provenance of these 102 items by comparing the proportions of diagnostic Quechuan features in the non-shared Proto-Quechua lexicon and in the shared lexicon (see table 7). For example, consider that $8.0 \%$ of non-shared Proto-Quechua roots begin in ${ }^{*} \mathrm{w}$, and the rest $(92.0 \%)$ do not. Since I have established that the $17 *_{\mathrm{w}}$ initial roots in the shared lexicon likely originate in Quechua, those surely also come along with a similar proportion of non-*w-initial Quechuan roots in the shared lexicon, most of which are otherwise undetectable as Quechuan because of their lack of diagnostic features. ${ }^{20}$

It is, of course, impossible to use these patterns to arrive at a precise estimation of how much of the shared lexicon comes from Quechua. However, because the proportion of diagnostic Quechuan features between the nonshared Proto-Quechua lexicon and the shared Proto-Quechua/Proto-Aymara lexicon are roughly comparable, we can at least be relatively certain that the great majority of the 144 shared lexical items were borrowed from Pre-ProtoQuechua into Pre-Proto-Aymara. If this is so, then little of the Proto-Quechua lexicon likely comes from Pre-Proto-Aymara. Overall, between these 144 shared items that appear to be mostly Quechuan and the 22 partially shared Proto-Aymara items that have Quechuan diagnostic features, it may be that well more than a third of the 496 reconstructed Proto-Aymara lexical items originate in Pre-Proto-Quechua.

5. Conclusions and directions for further research. A great number of resemblances between the Quechuan and Aymaran languages are attributable to an extraordinarily complex and multilayered relationship of

${ }^{20}$ The large disparity in the frequencies of root-final codas in table 7 is due to the fact that these features often appear in Quechuan forms that are not usually borrowed, such as pronouns, interrogatives, and demonstratives. 
contact, which began before their respective proto-languages diverged into families centuries or millennia ago and has continued to the present day. But while most linguists agree on this account, the nature of that contact has remained something of a black box, and there has been little attempt to understand the nature of the languages as they might have been before their initial period of contact. This paper has attempted to contribute to that effort by demonstrating a method for separating the Pre-Proto-Quechua and Pre-Proto-Aymara lexicons, offering some observations on the phonological systems of those languages (particularly of Pre-Proto-Aymara), and giving reconstructions and provenances of several hundred lexical items.

These findings raise as many questions as they answer. First, although many of the similarities between the Quechuan and Aymaran languages disappear when the successive layers of lexical borrowing are stripped away, a number of them remain, including similar phonemic inventories and a residue of suggestive lexical resemblances (Campbell 1995). In other words, it is not the case that all of the resemblances between the two language families can be explained by the identifiable periods of language contact. A methodological prerequisite for determining whether the remaining resemblances are due to earlier contact, shared descent, or chance-in other words, an adequate test of a Quechuan-Aymaran genetic grouping-is a prior reckoning of the subsequent history of language contact between the Aymaran and Quechua families, such as outlined in this paper. However, even if Quechuan and Aymaran do descend from a common proto-language, it may be that the correspondences are by now so tenuous and so obscured by convergence that nothing can be said definitively on the subject.

Second, establishing a loose relative chronology of Quechuan-Aymaran convergence opens up new possibilities for understanding specific phenomena in each family. For instance, many Quechua roots appear to be lexicalized from morphologically complex constructions: Adelaar (1986:387) notes that verbs such as miči- 'to pasture' and miku- 'to eat' appear to comprise causative $-\check{c} i$ and reflexive $-k u$ (respectively) and an ancient monosyllabic verb root *mi- (see also Parker 1969c:26). Similarly, there are a great number of ProtoQuechua roots beginning in [wa] that have to do with hanging, tying, or pulling (*wata- 'to tie, repair', *watu 'cord, strap', *waאqa- 'necklace, pendant, to hang around the neck', *wanku- 'wrap, bundle, bandage', *wantu- 'to carry among two or more people', *waraka 'sling, slingshot', *warku- 'to hang up, to be hung up', *waska 'rope', to name just a few). This element might once have been a root or classifier, at a time even earlier than the Pre-Proto-Quechua stage described in this paper. Such recurrent elements—of which there are many-may provide a window into an early period in Pre-Proto-Quechua before it was transformed by its contact with Pre-Proto-Aymara, and they may suggest deeper links to other language families. Internal reconstruction of the Pre-Proto-Quechua person system may also provide a perspective on the 
changes that that language underwent upon its contact with Pre-Proto-Aymara (Adelaar 2009:184, 2010:242). However, an analysis of these phenomena can only proceed once it is clear which elements can be reconstructed in the various pre-proto-languages in question and which are the product of borrowing or later internal developments. I shall address this question in further work.

Third, coming to terms with the etymological compositions of the Quechuan and Aymaran languages on the basis of a large data set may turn up some patterns relevant to current ethnohistorical questions. For instance, in my sample of 1,471 Central Aymaran lexical items, approximately one third descend from Proto-Aymara (of which about a third can definitively be traced to Pre-Proto-Quechua and two-thirds to Pre-Proto-Aymara), and a quarter are explainable as later local borrowings from neighboring Quechuan languages. That leaves more than $40 \%$ of the lexicon that is, as yet, etymologically unaccounted for. Some of these are surely reflexes of Pre-Proto-Aymara lexemes that do not survive in Southern Aymara. However, this disconcertingly large portion of the Central Aymaran lexicon likely also comprises vestiges of the intricate mosaic of related and unrelated languages-including some that may have disappeared before being documented - that was disrupted and reconfigured over and over by unknown demographic, political, and sociolinguistic upheavals from prehistory to the present. Such a situation makes clear that one must exercise caution when interpreting linguistic prehistory from the contemporary representation of the Andean languages; however, a close analysis of this portion of the lexicon may also help resolve questions about the historical trajectory of the Central Andean languages, and it may turn up new connections that have not yet been considered.

\section{REFERENCES}

Academia Mayor de La Lengua Quechua. 2005. Diccionario: Quechua-Español-Quechua, Qheswa-Español-Qheswa: Simi taqe. Cuzco: Academia Mayor de La Lengua Quechua (Qheswa Simi Hamut'ana Kurak Suntur).

AdelaAR, Willem F. H. 1982. Léxico del Quechua de Pacaraos. Lima: Centro de Investigación de Lingüística Aplicada, Universidad Nacional Mayor de San Marcos.

1986. La relación Quechua-Aru: Perspectivas para la separación del léxico. Revista Andina 4:379-426.

1987. Aymarismos en el Quechua de Puno. Indiana 11:223-31.

1996. La nasal velar en el Aymara y en el Jaqaru. Opción 12:5-19.

2009. Inverse markers in Andean languages: A comparative view. The Linguistics of Endangered Languages: Contributions to Morphology and Morpho-Syntax., ed. W. L. Wetzels, pp. 171-85. Utrecht: Netherlands Graduate School of Linguistics (LOT).

.2010. Trayectoria histórica de la familia lingüística Quechua y sus relaciones con la familia lingüística Aimara. Boletín de Arqueología PUCP 14:239-54.

2012a. Languages of the Middle Andes in areal-typological perspective: Emphasis on

Quechuan and Aymaran. The Indigenous Languages of South America: A Comprehensive Guide, ed. L. Campbell and V. Grondona, pp. 575-624. Berlin: Walter de Gruyter. 
.2012b. Modeling convergence: Towards a reconstruction of the history of QuechuanAymaran interaction. Lingua 122:461-69.

2013. Searching for undetected genetic links between the languages of South America. Historical Linguistics 2011: Selected Papers from the Twentieth International Conference on Historical Linguistics, Osaka, July 25-30, 2011, ed. R. Kikusawa and L. Reid, pp. 115-28. Amsterdam: John Benjamins.

Adelaar, Willem F. H., and Pieter Muysken. 2004. The Languages of the Andes. Cambridge: Cambridge University Press.

BarRanCA, Sebastián. 1876. Fragmentos de una gramática para el Cauqui. El Siglo 25-26:4-7, 21-26.

Bastien, Joseph William. 1978. Mountain of the Condor: Metaphor and Ritual in an Andean Ayllu. St. Paul: West Publishing Company.

Belleza Castro, Neli. 1995. Vocabulario Jacaru-Castellano, Castellano-Jacaru. Cusco: Centro regional Bartolomé de Las Casas.

Beresford-Jones, David G., and Paul Heggarty. 2010. Broadening our horizons: Towards an interdisciplinary prehistory of the Andes. Boletín de Arqueología PUCP 14:61-84.

Bertonio, Ludovico. 1612. Vocabulario de la lengua Aymara Juli, Chucuito: Francisco del Canto. [1984 edition by Xavier Albó and Félix Layme. Cochabamba: Centro de Estudios de la Realidad Económica y Social, Instituto Francés de Estudios Andinos and Museo Nacional de Etnografía y Folklore.]

Campbell, Lyle. 1995. The Quechumaran hypothesis and lessons for distant genetic comparison. Diachronica 12:157-200.

. 1997. American Indian Languages: The Historical Linguistics of Native America. Oxford: Oxford University Press.

Cerrón-Palomino, Rodolfo. 1976. Diccionario Quechua, Junín-Huanca. Lima: Ministerio de Educación.

. 1987. Lingüística Quechua. Cuzco: Centro de Estudios Rurales Andinos Bartolomé de las Casas.

. 1994. Quechumara: Estructuras paralelas del Quechua y del Aimara. La Paz: Centro de Investigación y Promoción del Campesinado

. 2000. Lingüística Aimara. Cuzco: Centro de Estudios Regionales Andinos Bartolomé de Las Casas.

2008. Voces del Ande: Ensayos sobre onomástica andina. Lima: Fondo Editorial de la Pontifícia Universidad Católica del Perú.

. 2013. Las lenguas de los incas. Frankfurt am Main: Peter Lang.

Coler, Matt. 2014. A Grammar of Muylaq'Aymara: Aymara as Spoken in Southern Peru. Leiden: Brill.

Соoк, Noble David. 1981. Demographic Collapse: Indian Peru, 1520-1620. Cambridge: Cambridge University Press.

CoRDERo, Luis. 1895/1992. Diccionario quichua-castellano y castellano-quichua Cuenca: Publicaciones de la Universidad de Cuenca [1992 edition, Quito: Corporación Editora Nacional.]

Cusihuamán GutiérRez, Antonio. 1976. Diccionario Quechua, Cuzco-Collao. Lima: Ministerio de Educación.

Deza Galindo, Juan Francisco. 1989. Jaya Mara Aru nuevo diccionario: Aymara-Castellano, Castellano-Aymara. Lima: Graphos 100 Editores.

Durston, Alan. 2007. Pastoral Quechua: The History of Christian Translation in Colonial Peru, 1550-1650. Notre Dame, Ind.: University of Notre Dame Press.

EmLen, Nicholas Q. 2014. Language and coffee in a trilingual Matsigenka-Quechua-Spanish frontier community on the Andean-Amazonian borderland of Southern Peru. Ph.D. dissertation, University of Michigan, Ann Arbor.

2016. Multilingualism in the Andes and Amazonia: A view from in-between. Journal of Latin American and Caribbean Anthropology. DOI: 10.1111/jlca.12250. 
FArfán, José María B. 1961. Diccionario conciso Castellano-Haqearu-Quechua. Revista del Museo Nacional 30:19-40.

Gayà-Vidal, Magdalena; Jean-Michel Dugoujon; Esther Esteban; Georgios Athanasiadis; Armando Rodríguez; Mercedes Villena; René Vasquez; and Pedro Moral. 2010. Autosomal and X chromosome Alu insertions in Bolivian Aymaras and Quechuas: Two languages and one genetic pool. American Journal of Human Biology 2:154-62.

Gayà-Vidal, Magdalena; Pedro Moral; Nancy Saenz-Ruales; Pascale Gerbault; Laure Tonasso; Mercedes Villena; René Vasquez; Claudio M. Bravi; and Jean-Michel Dugoujon. 2011. mtDNA and Y-chromosome diversity in Aymaras and Quechuas from Bolivia: Different stories and special genetic traits of the Andean Altiplano populations. American Journal of Physical Anthropology 145:215-30.

GonZÁlez Holguín, Diego. 1607. Gramática y arte nueva de la lengua general de todo el Perú llamada lengua qquichua o lengua del Inca. Lima: Francisco del Canto [1842 edition, Genoa: Pagano.]

Hardman, Martha J. 1966. Jaqaru: Outline of Phonological and Morphological Structure. The Hague: Mouton.

1983. Jaqaru: Compendio de estructura fonológica y morfológica. Lima: Instituto de Estudios Peruanos e Instituto Indigenista Interamericano.

1985. Aymara and Quechua: Languages in contact. South American Indian Languages: Retrospect and Prospect, ed. H. E. Manelis Klein and L. Stark, pp. 617-43. Austin: University of Texas Press. 1986. Comentario a Adelaar (1986). Revista Andina 4:408-13.

Heggarty, Paul. 2005. Enigmas en el origen de las lenguas andinas: Aplicando nuevas técnicas a las incógnitas por resolver. Revista Andina 40:9-57.

2011. Enterrando el esqueleto Quechumara. Estudios sobre lenguas andinas y amazónicas: Homenaje a Rodolfo Cerrón-Palomino, ed. W. F. H. Adelaar, P. Valenzuela, and R. Zariquiey, pp. 147-79. Lima: Fondo Editorial de la PUCP.

Heggarty, Paul, and David Beresford-Jones. 2010. Agriculture and language dispersals: Limitations, refinements, and an Andean exception? Current Anthropology 51:163-91.

2012. Archaeology and Language in the Andes Oxford: Oxford University Press.

Hosókawa, Koomei. 1980. Diagnóstico sociolinguiístico de la región norte de Potosí. La Paz: INEL.

Howard, Rosaleen. 2007. Por los linderos de la lengua: Ideologías lingüísticas en los Andes. Lima: Instituto de Estudios Peruanos.

Huayhua Pari, Felipe. 2009. Diccionario bilingüe polilectal aimara-castellano, castellano-aimara. San Marcos: Universidad Nacional Mayor de San Marcos, Fondo Editorial.

Laime Ajacopa, Teofilo; Efraín Cazazola; Félix Layme Pairumani; and Pedro Plaza Martínez. 2007. Diccionario bilingüe, iskay simipi yuyayk'ancha: Quechua-castellano, castellano-quechua. Ms., La Paz, Bolivia.

Landerman, Peter. 1994. Glottalization and aspiration in Quechua and Aymara reconsidered. Language in the Andes, ed. P. Cole, G. Hermon, and M. D. Martín, pp. 332-78. Newark: Latin American Studies Program, University of Delaware.

LANDERMAn, Peter. 1998. Internal reconstruction in Aymara and Quechua. The Life of Language: Papers in Linguistics in Honor of William Bright, ed. J. H. Hill, P. J. Mistry, and L. Campbell, pp. 35-57. Berlin: Mouton de Gruyter.

Mamani Mamani, Manuel A. 2002. Diccionario práctico bilingüe Aymara-Castellano, zona norte de Chile. Antofagasta: EMELNOR NORprint.

Mannheim, Bruce. 1985. Contact and Quechua-external genetic relationships. South American Indian Languages: Retrospect and Prospect, ed. H. E. Manelis Klein and L. Stark, pp. 644-88. Austin: University of Texas Press.

1986. Comentario a Adelaar (1986). Revista Andina 8:413-18.

1991. The Language of the Inka since the European Invasion. Austin: University of Texas Press. 
. n.d. ". . . A current of its own making": Functional targets in historical phonology. Ms.

Mannheim, Bruce, and Madeleine Newfield. 1982. Iconicity in phonological change. Papers from the Fifth International Conference on Historical Linguistics, ed. A. Ahlqvist, pp. 211-22. Amsterdam: John Benjamins.

Michael, Lev; Will Chang; and Tammy Stark. 2014. Exploring phonological areality in the Circum-Andean region using a naive Bayes classifier. Language Dynamics and Change 4:27-86.

Ministerio de EduCACIÓn. 2009. Kichwa yachakukkunapa shimiyuk kamu [Kichwa Dictionary for Students]. Quito: Ministerio de Educación.

MidDENDORF, ERnST W. 1891. Die Aymará Sprache. Leipzig: F.A. Brockhaus.

MuRRA, John V. 1972. El control vertical de un máximo de pisos ecológicos en la economía de las sociedades andinas. Visita de la provincia de León de Huánuco en 1562,vol. 2, ed. J. V. Murra, pp. 429-62. Huánuco, Perú: Universidad Nacional Hermilio Valdizán.

Muysken, Pieter. 2011. Modelling the Quechua-Aymara relationship: Structural features, sociolinguistic scenarios, and possible archeological evidence. Archaeology and Language in the Andes: A Cross-Disciplinary Exploration of Prehistory, ed. P. Heggarty and D. BeresfordJones, pp. 85-110. Oxford: Oxford University Press.

Orr, Carolyn, and Robert E. Longacre. 1968. Proto-Quechumaran. Language 44:528-55.

Orr, Carolyn, and Betsy Wrisley. 1965/1981. Vocabulario quichua del oriente del Ecuador. Quito: Instituto Lingüístico de Verano.

Park, Marinell; Nancy Weber; and Víctor Cenepo Sangama. 1976. Diccionario Quechua, San Martín. Lima: Ministerio de Educación.

Parker, Gary J. 1963. La clasificación genética de los dialectos Quechuas. Revista del Museo Nacional 32:241-52. 1969a. Ayacucho Quechua Grammar and Dictionary. The Hague: Mouton.

1969b. Comparative Quechua phonology and grammar I: Classification. University of Hawaii Working Papers in Linguistics 1:65-87. .1969c. Comparative Quechua phonology and grammar III: Proto-Quechua lexicon. University of Hawaii Working Papers in Linguistics 1:1-61. . 1973. On the evidence for complex stops in Proto-Quechua. IJAL 39:106-10.

Parker, Gary J., and Amancio Chávez. 1976. Diccionario quechua, Ancash-Huailas. Lima: Ministerio de Educación.

QuesadA, Félix. 1976. Diccionario quechua, Cajamarca-Cañaris. Lima: Ministerio de Educación.

Shimelman, Aviva. Forthcoming. A Lexicon of Yauyos Quechua. Berlin: Language Science Press.

Stark, Louisa R. 1975. A reconsideration of Proto-Quechua phonology. Lingüística e indigenismo moderno de América, Trabajos presentados al XXXIX CIA, pp. 209-19. Lima: IEP.

TAYLOR, Gerald. 1979. Diccionario normalizado y comparativo Quechua: Chachapoyas-Lamas. Paris: L'Harmattan.

Tschudi, Johann Jakoв Von. 1884. Organismus der Khetšua-Sprache. Leipzig: F. A. Brockhaus. Torero, Alfredo. 1964. Los dialectos quechuas. Anales Científicos 2:446-78.

. 1984. El comercio lejano y la difusión del Quechua: El caso de Ecuador. Revista Andina 2:367-402.

2002. Idiomas de los Andes: Lingüística e historia. Lima: Instituto Francés de Estudios Andinos: Editorial Horizonte.

URTON, GARY. 2012. The herder-cultivator relationship as a paradigm for archaeological origins, linguistic dispersals, and the evolution of record-keeping in the Andes. Archaeology and Language in the Andes, ed. P. Heggarty and D. Beresford-Jones, pp. 321-43. Oxford: Oxford University Press.

Wachtel, Nathan. 1977. The Vision of the Vanquished. Sussex: Harvester Press Hassocks. 
(C2017 by The University of Chicago. All rights reserved.

\begin{abstract}
APPENDIX
PERSPECTIVES ON THE QUECHUA-AYMARA CONTACT RELATIONSHIP AND THE LEXICON AND PHONOLOGY OF PRE-PROTO-AYMARA
\end{abstract}

\author{
NiCHOLAS Q. EMLEN
}

[IJAL, VOL. 83, NO. 2, APRIL 2017, PP.105-38]

\begin{abstract}
APPENDIX A
Proto-Quechua AND PROTO-Aymara ReCONSTRUCTIONS AND PROVENANCES
\end{abstract}

This appendix presents the 566 Proto-Quechua and 496 Proto-Aymara reconstructed lexical items (a total of 1,062) that form the empirical basis of this paper (for a synopsis of these reconstructions, see table 3 in the text). The lists are aligned in parallel columns, but because 144 reconstructed items are shared by both protolanguages, there are a total of 918 rows. These lists are alphabetized by Proto-Quechua lexeme; one drawback to this presentation is that some of the Proto-Aymara items are not in alphabetical order (for this reason, aspiration and glottalization are disregarded in the alphabetic sorting of the Proto-Aymara terms). The items in each proto-language that are not attested in any source in the other language family (i.e. the non-shared 225 ProtoQuechua and 231 Proto-Aymara lexemes discussed throughout the paper) are given in boldface type. 686 of the 918 reconstructed forms were assigned a provenance (427 Quechuan, marked with Q, and 259 Aymaran, marked with A) on the basis of the criteria detailed in $\mathbf{4 . 4}$ in the text.

Information about the data used in these reconstructions can be found in $\mathbf{3}$ in the text, and the methods are described in 4. The reconstructions are based on CerrónPalomino's accounts of the evolution of the Quechuan (1987) and Aymaran (2000) families, with minor modifications described in 4.1. The Aymaran list agrees to a large extent with the reconstructions and correspondences proposed by Cerrón-Palomino (2000:116-87, 344-69), but differs somewhat due to the sources consulted and the particular empirical criteria used here. Similarly, the Quechuan reconstructions given here mostly confirm those proposed by Parker (1969); however, some items in that list were not included because they did not meet our empirical thresholds, and the availability of data from a wider array of Quechuan languages allowed us to reconstruct forms not listed in that work. Parker's reconstruction also provided helpful guidance on English glossing.

A note on glossing. Two comments are in order regarding the glosses offered below. First, many Andean concepts do not have straightforward Euro-American counterparts, and are thus difficult to gloss. For example, Mannheim (2015:214) observes that the notion of waka (wak'a in some Southern Quechua varieties) can serve as a noun 
or adjective indicating "a cleft, a fissure, a cavern, or a crevice" in the land or on the body (e.g., the spaces between the fingers, the butt crack), a person with a cleft lip, six fingers, or other physical deformities, and dangerous, evil, or special places in the landscape. Used as a verb, it can mean 'to furrow (plowing)', 'to crack (skin)', or 'to transform from domestic to wild'. These belong to an ontologically coherent category for many Quechua speakers, but they are impossible to capture in a simple English gloss (see Mannheim 2015 for more on this point). Thus some glosses given here include several senses, but should not be interpreted as exhaustive (much less anthropologically reliable) representations of the concepts; this is simply a limitation of the word list format.

Second, some lexical items that are broadly attested across the Quechuan and Aymaran families have taken on new meanings since the colonial period, and in some cases these modern meanings have obscured their earlier usages. For instance, among some speakers and in some sources, waka has come to mean simply 'idol' or 'sacred object or place' following centuries of missionary interpretations and interventions. Similarly, Durston (2007:211-12) points out that the pre-Columbian Quechua notion of huča, which he describes as "a duty or debt in a social relationship of reciprocity, especially relationships between a person or social group and a huaca," was codified by the colonial religious authorities in the sixteenth century as the most appropriate translation of 'sin'. In some modern sources across the Quechuan varieties this Christian meaning of huča has largely overwhelmed the pre-Columbian meaning, which presents a problem for the semantic reconstruction of the term. Another example is the PanQuechuan verb ranti-, which is usually glossed in modern bilingual dictionaries as 'to buy' (and sometimes 'to sell'). However, the form of exchange suggested by those glosses was foreign to the pre-Columbian political economy, and at that time the term ranti- appears to have meant 'to substitute, replace', or when used as a noun, 'substitute, replacement' (Mannheim 2015:210). This sense of ranti- persists in vernacular usage among some Quechua speakers today, and appears in some colonial-era (and more rarely, modern) linguistic sources. Where possible, I have attempted to provide older senses of such reconstructed items, but it is likely that many of these have undergone semantic change since the colonial period (and, of course, during the long period between the proto-language stage and the colonial period). Thus, the original meanings of some reconstructed terms are probably lost to time.

\begin{tabular}{|l|l|l|l|l|}
\hline $\begin{array}{l}\text { Proto- } \\
\text { Quechua }\end{array}$ & $\begin{array}{l}\text { Proto- } \\
\text { Aymara }\end{array}$ & & Origin \\
\hline & & *ača & 'old' & A \\
\hline *ačka & 'many, much' & & & Q \\
\hline $\begin{array}{l}* \text { ački *akči } \\
\sim \text { *ačik }\end{array}$ & 'light' & & & Q \\
\hline & & *ačuma & 'cactus species' & A \\
\hline & & *atşa & 'large' & A \\
\hline
\end{tabular}


(C2017 by The University of Chicago. All rights reserved.

\begin{tabular}{|c|c|c|c|c|}
\hline & & *atși & 'many, much' & $\mathrm{A}$ \\
\hline & & *ats'i- & 'to dig, scratch' & $\mathrm{A}$ \\
\hline & & *atsima- & 'to tell, inform' & $\mathrm{A}$ \\
\hline \multirow{4}{*}{$\begin{array}{l}\text { *atspi- *ašpi } \\
\sim \text { *aspi- }\end{array}$} & 'to dig, scratch' & & & $\mathrm{Q}$ \\
\hline & & *atsu- & $\begin{array}{l}\text { 'to chew, bite down on, } \\
\text { hold in teeth' }\end{array}$ & \\
\hline & & *aka & 'here' & $\mathrm{A}$ \\
\hline & & $* a k^{\mathbf{h}} \mathbf{i}$ & 'to find, meet' & $\mathrm{A}$ \\
\hline $\begin{array}{l}\text { *akKa- } \\
\text { *akra- }\end{array}$ & 'to choose' & & & $\mathrm{Q}$ \\
\hline *akKu- & 'to stammer, stutter' & & & $\mathrm{Q}$ \\
\hline \multirow[t]{5}{*}{ *aku- } & 'to chew' & & & $\mathrm{Q}$ \\
\hline & & *aku & 'flour' & \\
\hline & & *ala- & 'to buy' & $\mathrm{A}$ \\
\hline & & *ali & 'plant, stem' & A \\
\hline & & *alu & 'brother of woman' & $\mathrm{A}$ \\
\hline \multirow[t]{2}{*}{ *aKa- } & $\begin{array}{l}\text { 'to dig up, harvest } \\
\text { potatoes' }\end{array}$ & & & Q \\
\hline & & *a人či & 'grandchild' & $\mathrm{A}$ \\
\hline *aAi & 'good' & & & $\mathrm{Q}$ \\
\hline *a人pa & 'earth, land, soil' & & & $\mathrm{Q}$ \\
\hline \multirow[t]{2}{*}{$* a \Lambda q u$} & 'dog' & & & \\
\hline & & $* \mathrm{a} \wedge \mathrm{u}$ & 'penis' & \\
\hline \multirow[t]{2}{*}{ *ama } & $\begin{array}{l}\text { 'not' (prohibitive } \\
\text { negator) }\end{array}$ & & & Q \\
\hline & & *ama- & $\begin{array}{l}\text { 'to think, know, } \\
\text { remember' }\end{array}$ & $\mathrm{A}$ \\
\hline \multirow[t]{3}{*}{ *ami- } & 'to get fed up, sick of' & & & Q \\
\hline & & *ampara & 'hand' & $\mathrm{A}$ \\
\hline & & *amputa & 'up, uphill' & $\mathrm{A}$ \\
\hline *amu- & $\begin{array}{l}\text { 'to hold in mouth or } \\
\text { between teeth' }\end{array}$ & & & $\mathrm{Q}$ \\
\hline \multirow[t]{2}{*}{ *ana } & 'birthmark, mole' & & & Q \\
\hline & & *ana- & 'to herd' & $\mathrm{A}$ \\
\hline *anaku & 'woman's garment' & *anaku & 'woman's garment' & \\
\hline *anaq & 'hard' & & & $\mathrm{Q}$ \\
\hline \multirow[t]{2}{*}{ *anča } & 'very, a lot' & *antsa & 'very, a lot' & \\
\hline & & $*$ ani- & 'to have sex' & $\mathrm{A}$ \\
\hline *anka & 'bird species' & & & $\mathrm{Q}$ \\
\hline
\end{tabular}


(C2017 by The University of Chicago. All rights reserved.

\begin{tabular}{|c|c|c|c|c|}
\hline *anku & 'tendon, nerve' & *anku & 'tendon, nerve' & \\
\hline & & *anqa & 'outside, above' & A \\
\hline & & *ansa- & 'to yawn' & \\
\hline *anta & $\begin{array}{l}\text { 'copper, copper- } \\
\text { colored' }\end{array}$ & & & Q \\
\hline *aña- & 'to bark' & & & Q \\
\hline *añas & 'mammal species' & *aña(su) & 'mammal species' & $\mathrm{Q}$ \\
\hline \multirow[t]{2}{*}{ *apa- } & 'to carry, bring' & *apa- & 'to carry, bring' & \\
\hline & & *apa & 'old woman' & A \\
\hline *api & 'a gelatinous porridge' & & & $\mathrm{Q}$ \\
\hline \multirow[t]{3}{*}{ *apta- $^{-}$} & $\begin{array}{l}\text { 'to grasp, grab, carry } \\
\text { in the hand, fist' }\end{array}$ & & & \\
\hline & & $* a q^{\text {hi }}$ & $\begin{array}{l}\text { 'cave, cliff, crag, } \\
\text { ravine' }\end{array}$ & A \\
\hline & & $*$ aqru- & 'to vomit' & Q \\
\hline \multirow[t]{2}{*}{ *aqtu- } & $\begin{array}{l}\text { 'to vomit, spit up, } \\
\text { drool' }\end{array}$ & & & Q \\
\hline & & $\begin{array}{l}\text { *araqa } \\
\text { *araya }\end{array}$ & 'up, above' & A \\
\hline \multirow[t]{2}{*}{ *arí } & 'yes' & & & Q \\
\hline & & *ari & $\begin{array}{l}\text { 'pointed, sharp, } \\
\text { summit' }\end{array}$ & $\mathrm{A}$ \\
\hline \multirow[t]{4}{*}{ *arma- } & 'to bathe' & & & Q \\
\hline & & *arpha- & $\begin{array}{l}\text { 'to desist, retire, move } \\
\text { away' }\end{array}$ & A \\
\hline & & *aru- & 'language, to speak' & A \\
\hline & & *aruma & 'night' & A \\
\hline \multirow[t]{2}{*}{ *arwi- } & $\begin{array}{l}\text { 'to tangle up, twist } \\
\text { fibers' }\end{array}$ & & & Q \\
\hline & & *asa- & $\begin{array}{l}\text { 'to carry in a } \\
\text { container' }\end{array}$ & A \\
\hline \multirow[t]{2}{*}{ *asi- } & 'to laugh' & & & Q \\
\hline & & $*^{*}$ ask $^{\mathrm{h}} \mathrm{i}-$ & 'to ask' & \\
\hline *aswa & $\begin{array}{l}\text { 'chicha (fermented } \\
\text { corn beverage)' }\end{array}$ & & & Q \\
\hline *ašna- & 'to stink' & & & Q \\
\hline \multirow[t]{2}{*}{ *ašta- } & 'to transport' & *ašta- & 'to transport' & Q \\
\hline & & $* a t^{\text {ha }} \mathbf{a}$ & 'seed' & A \\
\hline *ati(pa)- & $\begin{array}{l}\text { 'to defeat, endure, be } \\
\text { able' }\end{array}$ & *atipa- & 'to defeat' & \\
\hline *atuq & 'fox' & & & Q \\
\hline
\end{tabular}


(C2017 by The University of Chicago. All rights reserved.

\begin{tabular}{|c|c|c|c|c|}
\hline *awa- & 'to weave' & & & Q \\
\hline & & *awati- & 'to graze, pasture' & $\mathrm{A}$ \\
\hline *awki & $\begin{array}{l}\text { 'old man, grandfather, } \\
\text { man of respect, spirit' }\end{array}$ & & & \\
\hline *awhi- & 'to weave' & & & $\mathrm{Q}$ \\
\hline *awqa & 'enemy, demon, devil' & & & \\
\hline \multirow[t]{2}{*}{ *aya } & ‘corpse, cadaver’ & & & Q \\
\hline & & *aya- & $\begin{array}{l}\text { 'to carry (long } \\
\text { objects)' }\end{array}$ & $\mathrm{A}$ \\
\hline \multirow[t]{2}{*}{ *ayča } & 'meat, flesh' & & & $\mathrm{Q}$ \\
\hline & & *aytsi- & 'to rinse, stir' & \\
\hline *ayKu & $\begin{array}{l}\text { 'unit of social } \\
\text { organization' }\end{array}$ & & & Q \\
\hline *aypa- & 'to reach, be enough' & & & $\mathrm{Q}$ \\
\hline *ayqi- & 'to flee' & & & Q \\
\hline *aysa- & $\begin{array}{l}\text { 'to pull, drag, haul } \\
\text { with rope' }\end{array}$ & & & Q \\
\hline \multirow[t]{2}{*}{ *aywi- } & 'to stir, beat' & *aywi- & $\begin{array}{l}\text { 'to rinse, wash, flow } \\
\text { (water)' }\end{array}$ & \\
\hline & & *čačaku(ma) & 'tree species' & $\mathrm{A}$ \\
\hline *čaka & 'bridge, form of cross' & *čaka & 'bridge, form of cross' & \\
\hline *čaki & 'dry, to dry' & & & \\
\hline \multirow[t]{2}{*}{ *čakma- } & $\begin{array}{l}\text { 'to plow earth for } \\
\text { planting' }\end{array}$ & & & Q \\
\hline & & *č’aКa- & 'to splash, sprinkle' & \\
\hline \multirow[t]{2}{*}{ *ča $\Lambda$ wa } & 'fish' & *čaরwa & 'fish' & \\
\hline & & *č́ama- & $\begin{array}{l}\text { 'dark, darkness, night, } \\
\text { to become night, close } \\
\text { eyes, blink' }\end{array}$ & $\mathrm{A}$ \\
\hline *čampa & 'turf, sod, clod' & *č́ampa & 'turf, sod, clod' & \\
\hline \multirow[t]{2}{*}{ *čamqa- } & $\begin{array}{l}\text { 'to smash, crush, } \\
\text { grind, throw rock' }\end{array}$ & *čamqa- & 'to smash, crush, grind' & \\
\hline & & $\begin{array}{l}\text { *̌c'api } \\
\text { *pači }\end{array}$ & 'thorn, splinter' & $\mathrm{A}$ \\
\hline *čapra & 'tree branch' & & & $\mathrm{Q}$ \\
\hline *čapu- & $\begin{array}{l}\text { 'to mix (liquids), } \\
\text { infuse, blend' }\end{array}$ & & & Q \\
\hline *čaqču- & 'to spray, sprinkle' & *č’aqču- & $\begin{array}{l}\text { 'to spray, sprinkle, } \\
\text { splash onto ground' }\end{array}$ & Q \\
\hline
\end{tabular}


(C2017 by The University of Chicago. All rights reserved.

\begin{tabular}{|c|c|c|c|c|}
\hline *čaqKa- & $\begin{array}{l}\text { 'to frame a roof, fasten } \\
\text { together pieces of } \\
\text { wood' }\end{array}$ & & & Q \\
\hline *čarki & 'dried meat' & *č'arki & 'dried meat' & \\
\hline *čawča & $\begin{array}{l}\text { 'early-ripening or } \\
\text { damaged potato; } \\
\text { potato variety' }\end{array}$ & & & Q \\
\hline *čay & 'that' & & & $\mathrm{Q}$ \\
\hline \multirow[t]{2}{*}{$\begin{array}{l}\text { *čiču- * *čiči- } \\
\sim \text { *čuču- }\end{array}$} & $\begin{array}{l}\text { 'breast, nipple, to } \\
\text { breast feed' }\end{array}$ & & & $\mathrm{Q}$ \\
\hline & & *čika- & 'knot, to tie, thread' & $\mathrm{A}$ \\
\hline \multirow[t]{6}{*}{ *čiki } & 'bad omen' & & & Q \\
\hline & & $\begin{array}{l}\text { *čilu- } \\
\text { *činu- }\end{array}$ & 'knot, cord, to tie' & A \\
\hline & & *č́’iKa- & 'to take steps, skip' & A \\
\hline & & *č’iKa- & $\begin{array}{l}\text { 'to cut up, peel, shuck, } \\
\text { abrade' }\end{array}$ & \\
\hline & & *č'i & 'bush species' & \\
\hline & & $\begin{array}{l}\text { *čiKqi } \\
\text { *čirqi }\end{array}$ & 'step (walking)' & A \\
\hline *čimpa & $\begin{array}{l}\text { 'opposite side (of } \\
\text { river, valley, road)' }\end{array}$ & & & $\mathrm{Q}$ \\
\hline \multirow[t]{5}{*}{ *činka- } & $\begin{array}{l}\text { 'to get lost, } \\
\text { disappear' }\end{array}$ & & & Q \\
\hline & & *činki & $\begin{array}{l}\text { 'sister of man, younger } \\
\text { sister, younger female } \\
\text { cousin' }\end{array}$ & $\mathrm{A}$ \\
\hline & & *činqi & 'vagina' & $\mathrm{A}$ \\
\hline & & *č’iñi & 'nit' & \\
\hline & & *čiñwi & 'bat (animal)' & A \\
\hline \multirow[t]{3}{*}{ *čipa } & $\begin{array}{l}\text { 'straw bundle or } \\
\text { basket' }\end{array}$ & *č'ipa & $\begin{array}{l}\text { 'straw bundle, net for } \\
\text { carrying' }\end{array}$ & \\
\hline & & *č́ipi- & $\begin{array}{l}\text { 'to shine, sparkle, spark, } \\
\text { blink' }\end{array}$ & \\
\hline & & *čiqa & 'true, truth' & A \\
\hline \multirow[t]{3}{*}{ *čiqta- } & 'to split, crack, shred' & & & Q \\
\hline & & *čiwči & 'bird, chick' & \\
\hline & & *č'iwu & 'shade, hat' & $\mathrm{A}$ \\
\hline *čučuqa & 'corn-based dish' & & & \\
\hline *čukču- & 'to tremble, shake' & & & $\mathrm{Q}$ \\
\hline *čukイa & 'hut' & & & $\mathrm{Q}$ \\
\hline
\end{tabular}


(C2017 by The University of Chicago. All rights reserved.

\begin{tabular}{|c|c|c|c|c|}
\hline *čuKa & $\begin{array}{l}\text { 'odd, uneven, } \\
\text { incomplete (of a pair)' }\end{array}$ & *č’uKa & $\begin{array}{l}\text { 'odd, even, incomplete } \\
\text { (of a pair)' }\end{array}$ & \\
\hline *čuKpi & 'corn variety' & & & Q \\
\hline *čuKu- & 'to melt, thaw' & & & Q \\
\hline \multirow[t]{3}{*}{ *čuma- } & 'to drain out, drip out' & & & \\
\hline & & *č́nmpi & $\begin{array}{l}\text { 'brown, coffee-colored, } \\
\text { auburn, red' }\end{array}$ & \\
\hline & & *č́'unču & $\begin{array}{l}\text { 'bloom, crest, } \\
\text { plumage, head' }\end{array}$ & A \\
\hline *čunčuイi & 'guts, intestines' & & & Q \\
\hline \multirow[t]{3}{*}{ *čuñu } & $\begin{array}{l}\text { 'chuño (dehydrated } \\
\text { potatoes)' }\end{array}$ & *č’uñu & $\begin{array}{l}\text { 'chuño (dehydrated } \\
\text { potatoes)' }\end{array}$ & \\
\hline & & *čupi & ‘soup’ & \\
\hline & & $\begin{array}{l}\text { *čupika } \\
\text { *čukipa }\end{array}$ & 'red' & A \\
\hline *čupu & 'boil, tumor' & *č’upu & 'boil, tumor' & \\
\hline \multirow[t]{2}{*}{ *čuqKu } & 'ear of corn' & *čuqKu & 'ear of corn' & Q \\
\hline & & *čuquKu & 'a mythical being' & A \\
\hline *čuri & 'child (of father)' & & & Q \\
\hline \multirow[t]{2}{*}{ *čuspi } & 'mosquito, fly' & & & $\mathrm{Q}$ \\
\hline & & *č́uši & 'smooth, blanket type' & \\
\hline \multirow[t]{2}{*}{ *čuta- } & 'to pull, stretch' & & & Q \\
\hline & & $\begin{array}{l}* \text { čuwa } \\
\text { *čuya }\end{array}$ & 'small bowl, container' & \\
\hline \multirow[t]{3}{*}{ *čuya- } & $\begin{array}{l}\text { 'clear, to become clear } \\
\text { (liquids)' }\end{array}$ & *č́nya & $\begin{array}{l}\text { 'clean, clear, pure } \\
\text { (liquids)' }\end{array}$ & \\
\hline & & *tşaka & 'chest' & A \\
\hline & & *ts'aka & 'bone' & A \\
\hline \multirow[t]{2}{*}{ *tşaki } & 'foot' & $*$ taki- & 'to step on' & \\
\hline & & *tşaki & 'path, road' & A \\
\hline \multirow[t]{3}{*}{ *tşakra } & 'agricultural plot' & & & Q \\
\hline & & *ts'ama & 'strength, energy' & A \\
\hline & & $* \operatorname{tsan}(\mathbf{a})$ & 'buzz' & A \\
\hline *tşani & 'value' & & & Q \\
\hline \multirow[t]{5}{*}{ *tsanka } & 'leg' & & & Q \\
\hline & & *ts'anka & 'yarn, woolen thread' & A \\
\hline & & *tsapa & 'nest' & A \\
\hline & & *ts'apa- & 'to fall down, stumble' & A \\
\hline & & *ts’aqa- & 'to split apart' & A \\
\hline
\end{tabular}




\begin{tabular}{|c|c|c|c|c|}
\hline & & *tşaqa- & 'drop, to drip' & A \\
\hline & & *ts'aqmi- & $\begin{array}{l}\text { 'sad, angry, bothered, } \\
\text { to bother, annoy' }\end{array}$ & \\
\hline *tșaqna- & 'to hobble an animal' & & & $\mathrm{Q}$ \\
\hline *tşaski- & 'to receive, accept' & & & $\mathrm{Q}$ \\
\hline *țawa & 'raw' & & & $\mathrm{Q}$ \\
\hline *tsawpi & 'center, middle' & & & $\mathrm{Q}$ \\
\hline *tşaya- & 'to arrive' & & & Q \\
\hline \multirow[t]{2}{*}{ *tșitşu } & 'pregnant' & & & $\mathrm{Q}$ \\
\hline & & *tś'ikma & 'pillow, head rest' & \\
\hline \multirow[t]{4}{*}{ *tsina } & 'female' & & & $\mathrm{Q}$ \\
\hline & & *tș'ina & 'butt' & A \\
\hline & & *ts'iqa & 'left' & A \\
\hline & & *tș'iqi & 'beetle' & $\mathrm{A}$ \\
\hline *tsiqni- & 'to hate, abhor' & & & $\mathrm{Q}$ \\
\hline \multirow[t]{6}{*}{ *tsirapa ${ }^{2}$} & $\begin{array}{l}\text { 'mist, drizzle, sun } \\
\text { shower, rainbow' }\end{array}$ & & & Q \\
\hline & & *tş'isa- & $\begin{array}{l}\text { 'fuzz, lint, to card, comb } \\
\text { wool' }\end{array}$ & $\mathrm{A}$ \\
\hline & & *ts'iti- & $\begin{array}{l}\text { 'to have a full } \\
\text { stomach' }\end{array}$ & $\mathrm{A}$ \\
\hline & & *ts'iwra- & $\begin{array}{l}\text { 'to milk, squeeze out } \\
\text { liquid, wring' }\end{array}$ & $\mathrm{A}$ \\
\hline & & *ts'iyara & 'black' & A \\
\hline & & *ts'uku- & 'to sew' & $\mathrm{A}$ \\
\hline *tşunka & 'ten' & *ţ̦unka & 'ten' & \\
\hline \multirow[t]{2}{*}{ *tşupa } & 'tail' & & & $\mathrm{Q}$ \\
\hline & & *tş'uqa- & $\begin{array}{l}\text { 'to tie up, bind up, } \\
\text { bandage' }\end{array}$ & $\mathrm{A}$ \\
\hline \multirow[t]{6}{*}{ *tsura- } & 'to put, place' & & & \\
\hline & & *(h)ač'i- & 'to carry (handful)' & $\mathrm{A}$ \\
\hline & & *hači(w)- & 'sneeze, to sneeze' & $\mathrm{Q}$ \\
\hline & & *hatşa- & 'to cry, moan' & $\mathrm{A}$ \\
\hline & & *haka- & 'to live, exist' & A \\
\hline & & *hak'a & 'near' & A \\
\hline \multirow[t]{4}{*}{ *haku } & 'Let's go!' & & & Q \\
\hline & & $*^{*} \mathbf{h a k}^{\mathrm{h}} \mathbf{u}-$ & 'to breathe, sigh' & A \\
\hline & & *hala- & $\begin{array}{l}\text { 'to fall, fly, run, go } \\
\text { out' }\end{array}$ & $\mathrm{A}$ \\
\hline & & *haKa & 'so, then, perhaps' & A \\
\hline
\end{tabular}




\begin{tabular}{|c|c|c|c|c|}
\hline & & *haKpa- & 'to lick' & A \\
\hline & & *haKu- & 'rain, to rain' & A \\
\hline & & *hama- & 'feces, to defecate' & A \\
\hline & & *(h)amp'atsu & 'toad' & \\
\hline$*$ hampi- $^{3}$ & $\begin{array}{l}\text { 'medicine, remedy, to } \\
\text { cure' }\end{array}$ & & & \\
\hline \multirow[t]{10}{*}{ *hana } & 'up, above, over' & & & Q \\
\hline & & *hanči & 'meat, flesh, skin' & $\mathrm{A}$ \\
\hline & & *hani & 'no, not' & A \\
\hline & & *ha(n)k $\mathbf{k}^{\mathrm{h}} \mathbf{a}-$ & $\begin{array}{l}\text { 'loose, baggy, to } \\
\text { widen' }\end{array}$ & $\mathrm{A}$ \\
\hline & & *(h)anq'u & 'white' & A \\
\hline & & *hapi & 'pregnant' & $\mathrm{A}$ \\
\hline & & *haqi & 'person' & A \\
\hline & & *haqu- & 'to throw' & $\mathrm{A}$ \\
\hline & & *hara- & $\begin{array}{l}\text { 'to untie, unstitch, take } \\
\text { off clothing' }\end{array}$ & A \\
\hline & & *haraphi & 'rib, ribs' & $\mathrm{A}$ \\
\hline \multirow[t]{2}{*}{$\begin{array}{l}\text { *harawi- } \\
\text { *yarawi- }\end{array}$} & $\begin{array}{l}\text { 'a type of song or } \\
\text { poem, to perform song } \\
\text { or poem' }\end{array}$ & & & $\mathrm{Q}$ \\
\hline & & *hari- & 'to wash, rinse' & $\mathrm{A}$ \\
\hline \multirow[t]{2}{*}{ *harka- } & $\begin{array}{l}\text { 'to impede, block, } \\
\text { detain, obstruct' }\end{array}$ & *hark'a- & $\begin{array}{l}\text { 'to impede, block, } \\
\text { detain, obstruct' }\end{array}$ & \\
\hline & & *haru & 'spicy, bitter, sour' & A \\
\hline \multirow[t]{2}{*}{ *hatun } & 'large' & & & $\mathrm{Q}$ \\
\hline & & *hawi- & 'to flow, drip, smear' & \\
\hline \multirow[t]{4}{*}{ *haya- } & 'spicy, to be spicy' & & & $\mathrm{Q}$ \\
\hline & & *hayV- & 'to leave behind' & $\mathrm{A}$ \\
\hline & & *haya & 'far away, long time' & A \\
\hline & & *hayča- & 'to fight, argue, kill' & $\mathrm{A}$ \\
\hline \multirow[t]{3}{*}{ *(h)ayka } & $\begin{array}{l}\text { 'how much, how } \\
\text { many' }\end{array}$ & & & \\
\hline & & *haynu & 'husband' & $\mathrm{A}$ \\
\hline & & *hayra- & $\begin{array}{l}\text { 'idle, dance, song, to } \\
\text { dance, sing, be idle' }\end{array}$ & A \\
\hline \multirow[t]{2}{*}{$\begin{array}{l}\text { *hayta- } \\
\text { *sayta- }\end{array}$} & 'to kick' & & & Q \\
\hline & & $*(\mathrm{~h}) \mathrm{iču}$ & 'straw, hay' & \\
\hline *hitşa- & $\begin{array}{l}\text { 'to spill, empty out a } \\
\text { vessel, scatter' }\end{array}$ & & & Q \\
\hline
\end{tabular}


(C2017 by The University of Chicago. All rights reserved.

\begin{tabular}{|c|c|c|c|c|}
\hline & & *(h)its'i- & $\begin{array}{l}\text { 'to scratch, rip, dig, } \\
\text { scrape' }\end{array}$ & \\
\hline & & $*(\mathbf{h}) \mathbf{i k} \mathbf{k}^{\mathrm{h}} \mathbf{a}-$ & 'to herd' & A \\
\hline & & *hik'i- & 'hiccup, to hiccup' & \\
\hline & & *hila- & $\begin{array}{l}\text { 'older brother, older } \\
\text { male relative; 'to } \\
\text { grow, exceed' }\end{array}$ & A \\
\hline & & *hinču & 'ear' & A \\
\hline & & *hipi- & 'chaff, to shear, thresh' & A \\
\hline & & $\begin{array}{l}\text { *hira } \\
\text { *hina }\end{array}$ & 'Let's go!' & $\mathrm{A}$ \\
\hline & & $\begin{array}{l}*(\mathrm{~h}) \text { irp'i- } \\
*(\mathrm{~h}) \mathrm{irp}^{\mathrm{h}} \mathrm{i}-\end{array}$ & $\begin{array}{l}\text { 'lap, apron, to carry in } \\
\text { the apron' }\end{array}$ & A \\
\hline \multirow[t]{5}{*}{ *hirpu- } & $\begin{array}{l}\text { 'to pour liquid or } \\
\text { grains into a } \\
\text { container, to stuff } \\
\text { into' }\end{array}$ & & & Q \\
\hline & & *hiša & $\begin{array}{l}\text { 'yes, sound for herding } \\
\text { animals' }\end{array}$ & A \\
\hline & & $*(h)$ itt $^{\mathrm{h}} \mathbf{i}-$ & $\begin{array}{l}\text { 'to crawl, drag one's } \\
\text { body on the ground' }\end{array}$ & A \\
\hline & & *hiwa- & 'to die' & A \\
\hline & & $\begin{array}{l}\text { *hiwasa } \\
\text { *hiwsa }\end{array}$ & 'we (inclusive)' & $\mathrm{A}$ \\
\hline \multirow[t]{2}{*}{ *huča } & $\begin{array}{l}\text { 'debt, obligation, } \\
\text { blame, transgression, } \\
\text { crime' }\end{array}$ & *huča & $\begin{array}{l}\text { 'debt, obligation, blame, } \\
\text { transgression, crime' }\end{array}$ & \\
\hline & & $*(h) u c ̌ ' a$ & 'size' & A \\
\hline \multirow[t]{4}{*}{$*$ huk *suk } & 'one' & & & Q \\
\hline & & *hukumari & 'bear' & \\
\hline & & *huma & 'you' & $\mathrm{A}$ \\
\hline & & *(h)untș'u & 'hot' & A \\
\hline \multirow[t]{4}{*}{ *hunta- } & 'full, to fill' & & & Q \\
\hline & & *hunu- & $\begin{array}{l}\text { 'to dig, harvest } \\
\text { potatoes' }\end{array}$ & A \\
\hline & & *hupa & 'he, she, they' & A \\
\hline & & $*^{* h u p h}$ uqu & 'foam' & $\mathrm{A}$ \\
\hline \multirow[t]{3}{*}{$*(\mathrm{~h}) \mathrm{uqu}-$} & 'wet, to wetten' & & & \\
\hline & & $*(\mathrm{~h}) \mathrm{uq}^{\mathrm{h}} \mathrm{u}$ & 'mud, swamp' & A \\
\hline & & *huta- & 'to come' & A \\
\hline *iča & 'maybe, perhaps' & & & $\mathrm{Q}$ \\
\hline
\end{tabular}




\begin{tabular}{|c|c|c|c|c|}
\hline & & *iču- & $\begin{array}{l}\text { 'to carry in arms, } \\
\text { hands' }\end{array}$ & A \\
\hline & & *iki- & 'to sleep' & A \\
\hline \multirow[t]{2}{*}{$*_{\mathbf{i} \mathbf{K} \mathbf{a}-}$} & 'to lack, be absent' & & & $\mathrm{Q}$ \\
\hline & & $*_{\mathrm{i} \Lambda \mathrm{a}}$ & 'amulet' & \\
\hline *iКawa & 'shuttle, warp' & *íkawa & 'shuttle, warp' & \\
\hline \multirow{4}{*}{ *ima } & 'what' & & & $\mathrm{Q}$ \\
\hline & & *ima- & $\begin{array}{l}\text { 'to bury, save, hide in } \\
\text { ground, sow' }\end{array}$ & $\mathrm{A}$ \\
\hline & & *inči & verbal crutch & A \\
\hline & & *inki- & $\begin{array}{l}\text { 'fortune, to administer } \\
\text { a cure or poison' }\end{array}$ & A \\
\hline \multirow[t]{8}{*}{ *inti } & 'sun' & *inti & 'sun' & \\
\hline & & *inuqa- & $\begin{array}{l}\text { 'to put something on, } \\
\text { in something else' }\end{array}$ & $\mathrm{A}$ \\
\hline & & *iña- & $\begin{array}{l}\text { 'to wade through } \\
\text { water' }\end{array}$ & $\mathrm{A}$ \\
\hline & & *iñatşa- & $\begin{array}{l}\text { 'servant, laborer, to } \\
\text { contract laborer' }\end{array}$ & A \\
\hline & & *ipa & 'aunt (father's sister)' & A \\
\hline & & *iqa- & $\begin{array}{l}\text { 'to carry, move, } \\
\text { spread out fabric' }\end{array}$ & A \\
\hline & & *ira- & $\begin{array}{l}\text { 'to carry small things } \\
\text { in hand? }\end{array}$ & $\mathrm{A}$ \\
\hline & & *irpa- & 'to escort, accompany' & A \\
\hline$*_{\text {isku } \sim * \text { išku }}$ & 'lime' & & & Q \\
\hline *isma- & 'to defecate' & & & Q \\
\hline *ismu- & 'to rot, decompose' & & & $\mathrm{Q}$ \\
\hline \multirow[t]{4}{*}{ *isqun } & 'nine' & & & Q \\
\hline & & *iša- & 'to hear, listen' & $\mathrm{A}$ \\
\hline & & *iši & $\begin{array}{l}\text { 'fabric, clothing, } \\
\text { blanket type' }\end{array}$ & A \\
\hline & & *išk'a- & 'to urinate' & \\
\hline *iškay & 'two' & & & $\mathrm{Q}$ \\
\hline *išku- & 'to shell (grain)' & & & $\mathrm{Q}$ \\
\hline \multirow[t]{4}{*}{ *išpa- } & 'to urinate' & & & $\mathrm{Q}$ \\
\hline & & *išst'a- & 'to close' & \\
\hline & & *iwa- & 'to carry straw' & $\mathrm{A}$ \\
\hline & & *iwqa- & $\begin{array}{l}\text { 'to advise, caution, } \\
\text { entrust' }\end{array}$ & A \\
\hline$* \mathbf{k a}-$ & 'to be' & & & $\mathrm{Q}$ \\
\hline
\end{tabular}


(C2017 by The University of Chicago. All rights reserved.

\begin{tabular}{|c|c|c|c|c|}
\hline *katsa- & 'to send, release' & & & $\mathrm{Q}$ \\
\hline *katsi & 'salt' & & & \\
\hline \multirow{2}{*}{ *katşka- } & 'to gnaw, chew' & & & $\mathrm{Q}$ \\
\hline & & *k'aka- & $\begin{array}{l}\text { 'crack, opening, to } \\
\text { crack' }\end{array}$ & $\mathrm{A}$ \\
\hline *kaイana & 'pan for toasting grain' & & & $\mathrm{Q}$ \\
\hline *kaКpa- & 'strength, force, to run' & & & \\
\hline *kaКwa & 'a weaving instrument' & & & $\mathrm{Q}$ \\
\hline *kama- & 'to create, order' & & & $\mathrm{Q}$ \\
\hline \multirow[t]{2}{*}{ *kamča- } & $\begin{array}{l}\text { 'toasted corn, to } \\
\text { toast' }\end{array}$ & & & Q \\
\hline & & *k'ana & 'braid' & A \\
\hline *kantsa & 'corral' & & & $\mathrm{Q}$ \\
\hline *kani- & 'to bite' & & & $\mathrm{Q}$ \\
\hline \multirow[t]{5}{*}{ *kanka- } & 'roasted, to roast, grill' & *kanka & 'roast (noun)' & \\
\hline & & $* k^{\text {hanka }}$ & 'dirty, rough' & A \\
\hline & & *k'apa- & $\begin{array}{l}\text { 'broken, fragile, to } \\
\text { break' }\end{array}$ & $\mathrm{A}$ \\
\hline & & *k'ara- & 'to carry embers' & A \\
\hline & & ${ }^{*} \mathbf{k}^{\mathrm{h}}$ ari- & $\begin{array}{l}\text { 'to cut (e.g., meat), } \\
\text { skin' }\end{array}$ & $\mathrm{A}$ \\
\hline \multirow[t]{2}{*}{ *karka } & 'dirty, dirt, manure' & & & \\
\hline & & ${ }^{*} \mathbf{k}^{\mathrm{h}}$ arma & 'male' & A \\
\hline$*$ karu & 'far away, long time' & & & Q \\
\hline *kaspa & 'ear of corn' & & & Q \\
\hline \multirow[t]{4}{*}{ *kašpi } & 'stick, wood' & & & $\mathrm{Q}$ \\
\hline & & $*$ katu- & 'to catch, hunt' & $\mathrm{A}$ \\
\hline & & *kawki & 'where' & $\mathrm{A}$ \\
\hline & & *k'awna & 'egg' & $\mathrm{A}$ \\
\hline *kawpu- & $\begin{array}{l}\text { 'to twist fibers, braid, } \\
\text { spin thread' }\end{array}$ & & & Q \\
\hline *kawsa- & 'to live (exist)' & & & Q \\
\hline \multirow[t]{3}{*}{ *kay } & 'this' & & & Q \\
\hline & & *kayu & 'foot' & A \\
\hline & & *k'iči- & $\begin{array}{l}\text { 'to pinch, peel with } \\
\text { fingernails' }\end{array}$ & A \\
\hline *kitsa- & 'to open' & & & Q \\
\hline *kitski & 'narrow, tight' & & & $\mathrm{Q}$ \\
\hline *kiki & 'same, self' & *kiki & 'same, self' & \\
\hline
\end{tabular}




\begin{tabular}{|c|c|c|c|c|}
\hline & & *k'ili- & $\begin{array}{l}\text { 'to yank out a plant by } \\
\text { the stem, stalk' }\end{array}$ & A \\
\hline \multirow[t]{3}{*}{ *kiКa } & 'moon, month' & & & Q \\
\hline & & $* \mathrm{k}^{\prime} \mathrm{i} K \mathrm{i}$ & 'kestrel' & \\
\hline & & *k'imi- & 'to have sex' & A \\
\hline \multirow[t]{2}{*}{ *kimsa } & 'three' & *kimsa & 'three' & \\
\hline & & *k'inču & 'sash, apron' & \\
\hline \multirow[t]{2}{*}{ *kinray } & $\begin{array}{l}\text { 'transverse, } \\
\text { horizontal direction, } \\
\text { along a hillside' }\end{array}$ & & & Q \\
\hline & & *k'intu & $\begin{array}{l}\text { 'ritual offering of coca } \\
\text { leaves, offering, small } \\
\text { bundle' }\end{array}$ & \\
\hline \multirow[t]{2}{*}{ *kinwa } & 'quinoa' & & & \\
\hline & & *k'iptsa & 'liver' & Q \\
\hline \multirow[t]{2}{*}{ *kipu- } & 'knot, to tie' & & & $\mathrm{Q}$ \\
\hline & & $*^{\text {h }}{ }^{\text {irkinču }}$ & 'armadillo species' & $\mathrm{A}$ \\
\hline *kiru & 'tooth' & & & Q \\
\hline \multirow[t]{2}{*}{ *kita } & $\begin{array}{l}\text { 'wild, untamed } \\
\text { (animals or plants)' }\end{array}$ & & & Q \\
\hline & & ${ }^{*} k^{\text {hita- }}$ & 'to send' & A \\
\hline *kuču & 'corner' & & & Q \\
\hline \multirow[t]{5}{*}{ *kuču- } & 'to cut' & *k ${ }^{\mathrm{h}} \mathrm{uču}-$ & $\begin{array}{l}\text { 'to cut, slice (e.g., with } \\
\text { knife, scissors)' }\end{array}$ & \\
\hline & & *k’utsi & 'flea, louse' & \\
\hline & & *kuka & 'coca' & \\
\hline & & *kuKaka & $\begin{array}{l}\text { 'older sister, older } \\
\text { woman' }\end{array}$ & \\
\hline & & ${ }^{*} \mathrm{k}^{\prime} \mathrm{u} \hat{\mathrm{k} u}$ & 'narrow' & $\mathrm{A}$ \\
\hline *kuKu & 'tree trunk, wood' & $\begin{array}{l}* \mathrm{k}^{\prime} \mathrm{u} \hat{\mathrm{Ku}} \sim \\
*^{*} \mathrm{k}^{\mathrm{h}} \mathrm{u} \hat{\mathrm{u}} \mathrm{u}\end{array}$ & 'tree trunk, wood' & \\
\hline *kumu- & 'to squat, bend down' & & & Q \\
\hline *kuna- & $\begin{array}{l}\text { 'to advise, } \\
\text { recommend, } \\
\text { communicate a } \\
\text { message' }\end{array}$ & & & Q \\
\hline $\begin{array}{l}\text { *kunan } \\
\text { *kanan }\end{array}$ & 'now' & & & Q \\
\hline *kunka & 'neck, voice' & *kunka & 'neck, voice, throat' & \\
\hline *kuntur & 'condor' & *kunturi & 'condor' & Q \\
\hline
\end{tabular}


(C2017 by The University of Chicago. All rights reserved.

\begin{tabular}{|c|c|c|c|c|}
\hline *kunya- & $\begin{array}{l}\text { 'to crackle (fire), } \\
\text { echo' }\end{array}$ & & & Q \\
\hline & & *kupi & 'right side' & $\mathrm{A}$ \\
\hline *kurku & 'hunchback, hunch' & & & \\
\hline *kurpa & 'clod, clump of earth' & & & \\
\hline *kuru & 'worm' & & & Q \\
\hline \multirow[t]{2}{*}{ *kurur } & 'ball of yarn, clew' & & & Q \\
\hline & & *kururu & 'navel' & $\mathrm{A}$ \\
\hline *kuši- & 'happy, to be happy' & *kuši- & 'happy, to be happy' & \\
\hline \multirow[t]{2}{*}{ *kušma } & $\begin{array}{l}\text { 'garment, tunic (e.g., } \\
\text { worn by Amazonians)' }\end{array}$ & & & $\mathrm{Q}$ \\
\hline & & *k'ušu(ru) & 'wavy, algae' & \\
\hline *kuta- & 'to grind' & & & $\mathrm{Q}$ \\
\hline *kuti- & 'to return' & & & Q \\
\hline *kuti & 'time, occasion' & *kuti & 'time, occasion' & \\
\hline \multirow[t]{2}{*}{ *kutu- } & $\begin{array}{l}\text { 'shortened, cropped, to } \\
\text { cut, chop (e.g., with } \\
\text { ax, saw), amputate' }\end{array}$ & *k'utşu- & $\begin{array}{l}\text { 'to cut, chop (e.g., with } \\
\text { ax, saw), amputate' }\end{array}$ & \\
\hline & & ${ }^{*} \mathbf{k}^{\mathrm{h}} \mathbf{u w a}$ & 'that, there' & $\mathrm{A}$ \\
\hline \multirow[t]{2}{*}{ *kuya- } & 'to love' & & & Q \\
\hline & & *k'uyi & 'guinea pig' & $\mathrm{A}$ \\
\hline \multirow[t]{16}{*}{ *kuyu- } & 'to move' & & & $\mathrm{Q}$ \\
\hline & & ${ }^{*} \mathbf{k}^{\mathrm{h}} \mathbf{u y u} \mathbf{u}$ & 'to whistle' & A \\
\hline & & *lamp’a & 'head' & A \\
\hline & & *lampa & 'shovel, hoe, flat' & \\
\hline & & $* \operatorname{la}(\mathrm{n}) \mathrm{k}^{\mathrm{h}} \mathrm{a}-$ & 'to trip, stumble' & $\mathrm{A}$ \\
\hline & & *la(n)q'a & 'dirt, soil, dust' & $\mathrm{A}$ \\
\hline & & $* \operatorname{la}(n) q^{h} a-$ & 'to carry, shovel mud' & $\mathrm{A}$ \\
\hline & & *lap'a & 'louse' & A \\
\hline & & *laq'u & 'worm' & $\mathrm{A}$ \\
\hline & & *laqra & 'tongue' & Q \\
\hline & & $*$ lari & $\begin{array}{l}\text { 'male in-laws, wife's } \\
\text { relative' }\end{array}$ & $\mathrm{A}$ \\
\hline & & *larqa & 'canal, irrigation ditch' & \\
\hline & & *laru- & 'to laugh' & $\mathrm{A}$ \\
\hline & & *lawa & 'wood, stick, firewood' & A \\
\hline & & *lik'i & 'fat, grease' & $\mathrm{A}$ \\
\hline & & *liwa- & $\begin{array}{l}\text { 'to serve food, hand } \\
\text { out goods' }\end{array}$ & $\mathrm{A}$ \\
\hline
\end{tabular}


(C2017 by The University of Chicago. All rights reserved.

\begin{tabular}{|c|c|c|c|c|}
\hline & & *luqa- & $\begin{array}{l}\text { 'to raise, insert hand } \\
\text { or arm' }\end{array}$ & A \\
\hline & & $\begin{array}{l}\text { *luqhi } \\
\text { *luq'i }\end{array}$ & 'stupid, crazy, deaf' & A \\
\hline & & *luqru & 'type of stew, soup' & Q \\
\hline & & $*_{\boldsymbol{K}} \mathbf{a}$ & 'greeting, interjection' & A \\
\hline & & $*_{\text {Kač’a }}$ & 'wet, watery' & A \\
\hline *Kaki- & 'sadness, to be sad' & * Kaki- & 'sadness, to be sad' & \\
\hline \multirow[t]{2}{*}{ * Kama } & 'llama' & & & $\mathrm{Q}$ \\
\hline & & * Kama- & $\begin{array}{l}\text { 'to harvest, harvest } \\
\text { potatoes, pick' }\end{array}$ & A \\
\hline * Kamka- & 'to touch, handle, feel' & * Kamk ${ }^{\mathrm{h} a}$ - & 'to touch, handle, feel' & \\
\hline \multirow[t]{2}{*}{ *Kampu } & 'soft, smooth' & *Катр’u & 'soft, smooth' & \\
\hline & & * Samq'i- & 'to crush, smash' & A \\
\hline *anqi & 'type of sandal' & & & Q \\
\hline *Kantu- & $\begin{array}{l}\text { 'shade, shadow, to } \\
\text { cast a shadow' }\end{array}$ & & & Q \\
\hline * Kañu *ñañu & $\begin{array}{l}\text { 'thin (cylindrical } \\
\text { objects)' }\end{array}$ & & & Q \\
\hline $\begin{array}{l}\text { *Kapča- } \\
\text { *apša- }\end{array}$ & $\begin{array}{l}\text { 'thin, flat, to touch, } \\
\text { squeeze, crush' }\end{array}$ & & & Q \\
\hline *Kapi- & $\begin{array}{l}\text { 'to squeeze, crush, } \\
\text { smoosh' }\end{array}$ & & & Q \\
\hline *Каq Ка- & 'to carve wood' & & & $\mathrm{Q}$ \\
\hline *Kaqwa- & 'to lick' & & & $\mathrm{Q}$ \\
\hline$*_{\text {Kasa }} \sim *_{\text {Kaša }}$ & 'heavy' & & & Q \\
\hline$*_{K}$ Kika & 'net, spider web' & & & $\mathrm{Q}$ \\
\hline * KikKa & 'type of shawl' & & & $\mathrm{Q}$ \\
\hline * KiKi- & 'burn, sore, to scald' & * Ki $\mathrm{i} K \mathrm{i}-$ & 'burn, sore, to scald' & \\
\hline \multirow[t]{2}{*}{ *Kipta } & $\begin{array}{l}\text { 'ash used for chewing } \\
\text { coca' }\end{array}$ & & & Q \\
\hline & & *Kiqwi & $\begin{array}{l}\text { 'phlegm, mucus, bodily } \\
\text { fluid' }\end{array}$ & Q \\
\hline * Kučka- & 'slippery, to slip, slide' & *Kučka- & 'slippery, to slip, slide' & Q \\
\hline \multirow[t]{2}{*}{ *Kuču- } & $\begin{array}{l}\text { 'to take off, strip, skin, } \\
\text { slip off, remove' }\end{array}$ & *Kuts'u- & $\begin{array}{l}\text { 'to take off, strip, skin, } \\
\text { slip off, remove' }\end{array}$ & \\
\hline & & $\begin{array}{l}* \text { Kuk }^{\mathrm{h}} \mathrm{u}-\sim \\
* \tilde{n} \mathrm{uk}^{\mathrm{h}} \mathrm{u}-\end{array}$ & $\begin{array}{l}\text { 'beard, muzzle, net for } \\
\text { carrying things, to pull } \\
\text { hair, beard' }\end{array}$ & A \\
\hline * KuKa- & 'lie, to lie, deceive' & & & \\
\hline
\end{tabular}


(C2017 by The University of Chicago. All rights reserved.

\begin{tabular}{|c|c|c|c|c|}
\hline$* \mathrm{Ku} \mathrm{Ku}$ & $\begin{array}{l}\text { 'unripe, newborn, } \\
\text { tender' }\end{array}$ & & & \\
\hline & & *'iump'i- & $\begin{array}{l}\text { 'to abound, overflow, } \\
\text { be many' }\end{array}$ & A \\
\hline * КuqKa & $\begin{array}{l}\text { 'flood, avalanche, } \\
\text { mudslide' }\end{array}$ & * КuqКа & $\begin{array}{l}\text { 'flood, avalanche, } \\
\text { mudslide' }\end{array}$ & Q \\
\hline * Kušpi- & $\begin{array}{l}\text { 'to slip, to leak out, to } \\
\text { lick a plate or pot } \\
\text { clean' }\end{array}$ & & & Q \\
\hline *Kušti- & $\begin{array}{l}\text { 'to peel, strip, } \\
\text { denude' }\end{array}$ & & & Q \\
\hline \multirow[t]{3}{*}{ * Kuta- } & 'to smear with mud' & & & Q \\
\hline & & ${ }^{*}$ mač'a- ${ }^{4}$ & $\begin{array}{l}\text { 'fallow, dry season, to } \\
\text { irrigate' }\end{array}$ & \\
\hline & & *mačaqa & 'new' & A \\
\hline *matsa- & 'to be drunk' & *matsa- & $\begin{array}{l}\text { 'drunk, liquor, to be } \\
\text { drunk' }\end{array}$ & \\
\hline *matsay & 'cave' & & & Q \\
\hline *matska & 'toasted grain flour' & & & Q \\
\hline$*_{\text {maki }}$ & 'hand, forearm' & & & $\mathrm{Q}$ \\
\hline *maKa- & 'to fast' & & & $\mathrm{Q}$ \\
\hline *maKi- & 'to taste, try' & *maKi- & 'to taste, try' & \\
\hline$*_{\mathrm{ma}} \mathrm{ki}-$ & $\begin{array}{l}\text { 'seedling, tree, to } \\
\text { plant, transplant' }\end{array}$ & & & \\
\hline *mana & 'no, not' & & & Q \\
\hline *manča- & 'to scare, be afraid' & & & Q \\
\hline \multirow[t]{3}{*}{ *manka } & 'pot' & & & Q \\
\hline & & *manq'a- & 'to eat' & A \\
\hline & & ${ }^{*} \operatorname{manq}^{\mathrm{h}} \mathbf{a}$ & $\begin{array}{l}\text { 'below, inside, } \\
\text { interior' }\end{array}$ & $\mathrm{A}$ \\
\hline$*$ manta- $^{5}$ & 'to spread out fabric' & & & \\
\hline *manya & $\begin{array}{l}\text { 'side, edge, border, } \\
\text { margin' }\end{array}$ & & & Q \\
\hline *maña- & 'to ask for, request' & & & Q \\
\hline \multirow[t]{2}{*}{ *maqa- } & 'to hit, punch, beat' & & & Q \\
\hline & & *maqhura & 'testicle' & A \\
\hline *maray & 'grinding stone' & & & $\mathrm{Q}$ \\
\hline *marka & 'town, village, region' & *marka & $\begin{array}{l}\text { 'town, village, region, } \\
\text { nation' }\end{array}$ & \\
\hline *marku & 'plant species' & ${ }^{*}$ mark $^{\mathrm{h}} \mathrm{u}$ & 'plant species' & \\
\hline *marqa- & 'to carry in the arms' & *marqa- & 'to carry in the arms' & \\
\hline
\end{tabular}


(C2017 by The University of Chicago. All rights reserved.

\begin{tabular}{|c|c|c|c|c|}
\hline *masa- & $\begin{array}{l}\text { 'to spread out in the } \\
\text { sun' }\end{array}$ & & & Q \\
\hline *maša & $\begin{array}{l}\text { 'brother-in-law, son- } \\
\text { in-law' }\end{array}$ & & & \\
\hline$*_{\text {masi }}$ & 'fellow, companion' & & & \\
\hline *mati & $\begin{array}{l}\text { 'gourd, vessel made } \\
\text { from gourd' }\end{array}$ & & & $\mathrm{Q}$ \\
\hline *mawka- & $\begin{array}{l}\text { 'used up, worn out, to } \\
\text { wear out' }\end{array}$ & & & $\mathrm{Q}$ \\
\hline \multirow[t]{5}{*}{ *may } & 'where' & & & $\mathrm{Q}$ \\
\hline & & *maya- & 'to go' & $\mathrm{A}$ \\
\hline & & *maya & 'one' & $\mathrm{A}$ \\
\hline & & *mayi- & $\begin{array}{l}\text { 'to ask for, request, } \\
\text { borrow' }\end{array}$ & A \\
\hline & & *mayruru & 'kidney' & \\
\hline$*_{\text {mayu }}$ & 'river' & & & \\
\hline *miči- & 'to pasture' & & & $\mathrm{Q}$ \\
\hline *mitşa & 'stingy' & *mits'a & 'stingy' & \\
\hline *miku- & 'to eat' & & & $\mathrm{Q}$ \\
\hline \multirow[t]{2}{*}{ *miKa- } & $\begin{array}{l}\text { 'to be disgusted, } \\
\text { nauseous' }\end{array}$ & & & \\
\hline & & *miSk'u- & 'to twist, screw' & $\mathrm{A}$ \\
\hline *miKpu- & 'to swallow' & & & $\mathrm{Q}$ \\
\hline$*_{\text {miKwa }}$ & 'wool' & & & $\mathrm{Q}$ \\
\hline$*$ mini- & 'weft, to weave' & & & Q \\
\hline *minka- & $\begin{array}{l}\text { 'type of labor } \\
\text { recruitment, to } \\
\text { contract labor' }\end{array}$ & *mink'a- & $\begin{array}{l}\text { 'type of labor } \\
\text { recruitment, to contract } \\
\text { labor' }\end{array}$ & \\
\hline 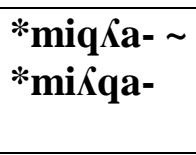 & $\begin{array}{l}\text { 'skirt, lap, apron, to } \\
\text { hold in skirt, lap, } \\
\text { apron' }\end{array}$ & & & Q \\
\hline *mira- & $\begin{array}{l}\text { 'to reproduce, } \\
\text { multiply' }\end{array}$ & $*$ mira- & 'to reproduce, multiply' & \\
\hline *mirkapa & 'snack, provisions' & & & $\mathrm{Q}$ \\
\hline *miški & 'sweet' & & & $\mathrm{Q}$ \\
\hline *mitka- & $\begin{array}{l}\text { 'to trip, fall down, } \\
\text { tumble } 6\end{array}$ & *t'inki- & 'to fall, slip, tumble' & Q \\
\hline *muča- & 'to kiss' & & & \\
\hline \multirow[t]{3}{*}{$*_{\text {mutska }}$} & 'mortar' & & & Q \\
\hline & & *mutsu- & 'punishment, to suffer' & \\
\hline & & $*$ muhu & 'seed' & \\
\hline
\end{tabular}


(C2017 by The University of Chicago. All rights reserved.

\begin{tabular}{|c|c|c|c|c|}
\hline & & $*^{*}$ muk $^{\mathrm{h}} \mathrm{i}-$ & 'to smell' & \\
\hline *muKi & 'tree species' & $*_{\text {muKi }}$ & 'tree species' & \\
\hline \multirow[t]{2}{*}{ *muna- } & 'to want, desire, love' & *muna- & 'to want, desire, love' & \\
\hline & & *muqsa & 'sweet' & \\
\hline *muqu & 'knob, joint, bump' & $*$ muqu & 'knob, joint, bump' & \\
\hline *muru & $\begin{array}{l}\text { 'spotted, stained, } \\
\text { multicolored' }\end{array}$ & & & Q \\
\hline \multirow[t]{2}{*}{ *muru } & 'seed, pit' & & & Q \\
\hline & & *muru & $\begin{array}{l}\text { 'blunted, cropped, } \\
\text { worn out' }\end{array}$ & A \\
\hline *muruču & 'corn variety' & & & Q \\
\hline *muspa- & $\begin{array}{l}\text { 'to daydream, be } \\
\text { delirious, rave' }\end{array}$ & & & Q \\
\hline \multirow[t]{2}{*}{ *musya- } & $\begin{array}{l}\text { 'to divine, sense, } \\
\text { realize, perceive' }\end{array}$ & $\begin{array}{l}* \text { musa- } \\
* \text { musu- }\end{array}$ & $\begin{array}{l}\text { 'to divine, sense, } \\
\text { realize, perceive' }\end{array}$ & Q \\
\hline & & *muši- & 'to watch over, guard' & A \\
\hline *mušuq & 'new' & & & $\mathrm{Q}$ \\
\hline$*$ muti & 'boiled corn kernels' & *mut'i & 'boiled corn kernels' & \\
\hline *mutki- & $\begin{array}{l}\text { 'to smell, perceive } \\
\text { odor' }\end{array}$ & & & Q \\
\hline \multirow[t]{3}{*}{ *muyu- } & $\begin{array}{l}\text { 'to turn around, spin, } \\
\text { rotate, circle' }\end{array}$ & *muyu- & $\begin{array}{l}\text { 'round, to turn around, } \\
\text { spin, rotate, circle' }\end{array}$ & \\
\hline & & *nak'a & 'sticky' & A \\
\hline & & $\begin{array}{l}* \text { nak }^{\mathrm{h}} \mathrm{a}-\text { } \\
\text { *nak'a- }\end{array}$ & 'to burn (intrans.)' & \\
\hline \multirow[t]{4}{*}{ *nana- } & 'to hurt, ache' & & & Q \\
\hline & & *nasa & 'nose' & $\mathrm{A}$ \\
\hline & & *naya & 'I' & A \\
\hline & & *nayra & 'eye' & A \\
\hline \multirow[t]{2}{*}{ *ni- } & 'to say, tell' & & & Q \\
\hline & & $*$ nik $^{\mathrm{h}} \mathbf{a}$ & $\begin{array}{l}\text { 'before, a moment } \\
\text { ago' }\end{array}$ & A \\
\hline *nina & 'fire' & $*$ nina & 'fire' & \\
\hline *niti- *ñiti- & 'to smash, crush' & & & \\
\hline *ñaka- & $\begin{array}{l}\text { 'with difficulty, to } \\
\text { suffer, experience } \\
\text { difficulty' }\end{array}$ & & & Q \\
\hline *ñaqča- & 'comb, to comb' & & & Q \\
\hline *ñati(n) & 'liver, internal organ' & & & Q \\
\hline \multirow[t]{2}{*}{$* \tilde{\mathbf{n a w i}}$} & 'eye' & & & Q \\
\hline & & *ñiq'i & 'mud' & \\
\hline
\end{tabular}


(C2017 by The University of Chicago. All rights reserved.

\begin{tabular}{|c|c|c|c|c|}
\hline & & *ñiqi- & 'to grind, press, stuff' & $\mathrm{A}$ \\
\hline & & $\begin{array}{l}\text { *ñuk'atșa } \\
\text { *ñak'utşa }\end{array}$ & 'hair' & A \\
\hline *ñuñu- & $\begin{array}{l}\text { 'breast, udder, to } \\
\text { nurse' }\end{array}$ & *ñuñu- & 'breast, udder, to nurse' & \\
\hline *ñuqa & 'I' & & & $\mathrm{Q}$ \\
\hline *ñuqančik & 'we (inclusive)' & & & Q \\
\hline \multirow[t]{2}{*}{ *pača } & $\begin{array}{l}\text { 'world, time, era, } \\
\text { circumstance' }\end{array}$ & *patsa & $\begin{array}{l}\text { 'world, time, era, } \\
\text { circumstance, sky' }\end{array}$ & \\
\hline & & *patsa & 'same' & A \\
\hline \multirow[t]{2}{*}{ *patşak } & 'hundred' & *patsaka & 'hundred' & $\mathrm{Q}$ \\
\hline & & *phatsu & $\begin{array}{l}\text { 'thick, densely planted } \\
\text { crops' }\end{array}$ & A \\
\hline *paka- & 'to hide' & & & $\mathrm{Q}$ \\
\hline \multirow[t]{2}{*}{ *paki- } & 'to break, smash' & *p'aki- & 'to break, smash' & \\
\hline & & $\begin{array}{l}* p^{\text {hala- }} \sim \\
* p^{\text {hari- }}\end{array}$ & $\begin{array}{l}\text { 'to twist fibers into } \\
\text { thread, string' }\end{array}$ & A \\
\hline *paКa- & 'to harvest, pick' & & & $\mathrm{Q}$ \\
\hline *paКqa- & $\begin{array}{l}\text { 'forked, pitchfork, to } \\
\text { bifurcate, split' }\end{array}$ & *p’a人qa- & 'forked, pitchfork' & \\
\hline *pampa- & $\begin{array}{l}\text { 'flat place, plain, open } \\
\text { land; to bury, cover } \\
\text { with earth, flatten } \\
\text { earth' }\end{array}$ & *p'ampa- & $\begin{array}{l}\text { 'flat place, plain, open } \\
\text { land; to bury, cover with } \\
\text { earth, flatten earth' }\end{array}$ & \\
\hline *pani & 'sister of man' & & & Q \\
\hline *panqa & 'corn husk' & & & \\
\hline *panta- & $\begin{array}{l}\text { 'to err, confuse, be } \\
\text { wrong' }\end{array}$ & *panta- & $\begin{array}{l}\text { 'to err, confuse, be } \\
\text { wrong' }\end{array}$ & \\
\hline \multirow[t]{2}{*}{ *papa } & 'potato' & & & \\
\hline & & $\begin{array}{l}\text { *paqaКi- } \\
\text { *paqaKa- }\end{array}$ & $\begin{array}{l}\text { 'all night, to stay up all } \\
\text { night' }\end{array}$ & \\
\hline *paqča & $\begin{array}{l}\text { 'waterfall, stream of } \\
\text { water' }\end{array}$ & *paqča & $\begin{array}{l}\text { 'waterfall, stream of } \\
\text { water' }\end{array}$ & Q \\
\hline \multirow[t]{6}{*}{ *paqtsa } & 'forehead' & & & $\mathrm{Q}$ \\
\hline & & ${ }^{*} \mathbf{p}^{\mathrm{h}} \mathbf{a q i}$ & 'breast, breast pocket' & $\mathrm{A}$ \\
\hline & & *paqši & 'moon' & Q \\
\hline & & *para & 'forehead' & A \\
\hline & & *parana & 'grinding stone' & A \\
\hline & & *p'arpa- & $\begin{array}{l}\text { 'ground corn, marrow, } \\
\text { type of mud, to tamp } \\
\text { down' }\end{array}$ & \\
\hline
\end{tabular}


(C2017 by The University of Chicago. All rights reserved.

\begin{tabular}{|c|c|c|c|c|}
\hline & & *paru & $\begin{array}{l}\text { 'toasted, golden-brown } \\
\text { color, corn variety' }\end{array}$ & A \\
\hline & & *phasa- & $\begin{array}{l}\text { 'untie, unstitch, } \\
\text { loosen' }\end{array}$ & A \\
\hline *paska- & $\begin{array}{l}\text { 'to untie, unstitch, } \\
\text { loosen' }\end{array}$ & & & Q \\
\hline *pašña & 'girl, young woman' & & & Q \\
\hline \multirow[t]{2}{*}{ *pata } & $\begin{array}{l}\text { 'terrace, platform, flat } \\
\text { place' }\end{array}$ & *pata & $\begin{array}{l}\text { 'terrace, platform, flat } \\
\text { place' }\end{array}$ & \\
\hline & & ${ }^{*} p^{h}$ awi- & 'to wind, spin thread' & A \\
\hline \multirow[t]{3}{*}{ *pay } & 'he, she' & & & Q \\
\hline & & *paya & 'two' & $\mathrm{A}$ \\
\hline & & *phaya- & 'to cook' & A \\
\hline *pi & 'who' & & & Q \\
\hline *piča- & 'to sweep, clean' & *piča- & 'to sweep, clean' & \\
\hline \multirow[t]{2}{*}{ *pičqa } & 'five' & *pičqa & 'five' & Q \\
\hline & & ${ }^{*} p^{\text {hitsul- }}$ & 'to knead, mix, stir' & A \\
\hline *piki & 'flea, chigger' & & & \\
\hline *piKpintu & 'butterfly, moth' & & & Q \\
\hline *piאu- & $\begin{array}{l}\text { 'crown, adornment, to } \\
\text { braid, tangle' }\end{array}$ & *piKu & $\begin{array}{l}\text { 'flower garland, crown, } \\
\text { adornment' }\end{array}$ & \\
\hline *pinkuKu & 'flute type' & $*$ pinkuKu & 'flute type' & \\
\hline *pinqa- & $\begin{array}{l}\text { 'shame, to be } \\
\text { ashamed' }\end{array}$ & $\begin{array}{l}* \text { *p'inqa- } \\
* \text { phinqa- }\end{array}$ & 'shame, to be ashamed' & \\
\hline *piña- & 'angry, to anger' & & & \\
\hline \multirow[t]{2}{*}{ * pirqa } & 'wall' & *pirqa & 'wall' & \\
\hline & & *pirwa & $\begin{array}{l}\text { 'granary, storage } \\
\text { container' }\end{array}$ & \\
\hline$*$ piruru & $\begin{array}{l}\text { 'whorl (part of } \\
\text { spinning wheel)' }\end{array}$ & *p $\mathrm{p}^{\mathrm{h}} \mathrm{i}$ uru & $\begin{array}{l}\text { 'whorl (part of spinning } \\
\text { wheel)' }\end{array}$ & \\
\hline *piši- & $\begin{array}{l}\text { 'little, to diminish, be } \\
\text { little, tire out' }\end{array}$ & *piši & 'a little' & \\
\hline \multirow[t]{4}{*}{${ }^{*}$ pišqu } & 'bird, bird species' & & & Q \\
\hline & & *p'ita- & 'to weave' & $\mathrm{A}$ \\
\hline & & ${ }^{*} p^{\text {hitu }}$ & 'pin' & $\mathrm{A}$ \\
\hline & & *p'iya- & $\begin{array}{l}\text { 'hole, opening, to cut } \\
\text { an opening, clear a } \\
\text { path' }\end{array}$ & $\mathrm{A}$ \\
\hline *pučka- & $\begin{array}{l}\text { 'spindle, to spin } \\
\text { thread' }\end{array}$ & & & Q \\
\hline
\end{tabular}


(C2017 by The University of Chicago. All rights reserved.

\begin{tabular}{|c|c|c|c|c|}
\hline *pučqu- & $\begin{array}{l}\text { 'fermented, sour, to } \\
\text { ferment, become sour' }\end{array}$ & *p'učqu- & 'fermented, to ferment' & Q \\
\hline \multirow[t]{2}{*}{ *puču- } & $\begin{array}{l}\text { 'leftover, to be left } \\
\text { over, exceed' }\end{array}$ & & & Q \\
\hline & & *ph utsa & 'daughter' & A \\
\hline *puka & 'red, colored' & & & Q \\
\hline *pukia- & 'to play' & & & Q \\
\hline *pukru & $\begin{array}{l}\text { 'hole, hollow, } \\
\text { concave' }\end{array}$ & *p’ukru & 'hole, hollow, concave' & Q \\
\hline *pukuču & 'bladder' & & & Q \\
\hline *pukyu & 'spring, well' & *pukyu & 'spring, well' & Q \\
\hline \multirow[t]{2}{*}{ *puKu } & 'shawl, blanket' & ${ }^{*} \mathrm{p}^{\mathrm{h}} \mathrm{u} \mathrm{Ku}$ & $\begin{array}{l}\text { 'fabric type, woman's } \\
\text { garment' }\end{array}$ & \\
\hline & & $* p^{h} u K u-$ & $\begin{array}{l}\text { 'to bubble, gurgle, } \\
\text { spurt, overflow' }\end{array}$ & A \\
\hline *puma & 'puma' & *puma & 'puma' & \\
\hline *puna & 'high grasslands' & & & Q \\
\hline *punki- & 'swollen, to swell' & *punki- & 'swollen, to swell' & \\
\hline *punku & 'door, entrance' & *punku & 'door, entrance' & \\
\hline *puñu- & 'to sleep' & & & Q \\
\hline \multirow[t]{2}{*}{ *pupu } & 'navel' & & & $\mathrm{Q}$ \\
\hline & & ${ }^{*} \mathbf{p}^{\mathrm{h}} \mathbf{u q a}$ & 'full, ripe' & $\mathrm{A}$ \\
\hline *puqu- & 'to ripen, mature' & *p'uqu- & 'to ripen, mature' & \\
\hline \multirow[t]{2}{*}{ puri- } & 'to travel, walk, roam' & *puri- & 'to come, arrive, return' & \\
\hline & & *phurka- & 'to grill, roast' & $\mathrm{A}$ \\
\hline \multirow[t]{2}{*}{ *puru } & $\begin{array}{l}\text { 'gourd, vessel made } \\
\text { from gourd' }\end{array}$ & $* \mathrm{p}^{\mathrm{h}}$ uru & ‘jug, basin’ & \\
\hline & & ${ }^{*} \mathbf{p}^{\mathrm{h}}$ usa- & 'to blow, inflate' & A \\
\hline \multirow[t]{2}{*}{ *pusaq } & 'eight' & & & Q \\
\hline & & $\begin{array}{l}*{ }^{*}{ }^{\prime} \mathrm{usu}-\sim \\
* \mathrm{p}^{\mathrm{h}} \mathrm{usu}(\mathrm{Ku})-\end{array}$ & $\begin{array}{l}\text { 'blister, swollen, to } \\
\text { scald' }\end{array}$ & \\
\hline \multirow[t]{2}{*}{ *puša- } & $\begin{array}{l}\text { 'to accompany, guide, } \\
\text { bring along, escort' }\end{array}$ & & & Q \\
\hline & & *puši & 'four' & $\mathrm{A}$ \\
\hline \multirow[t]{3}{*}{ *puyñu } & 'pitcher, jug' & & & Q \\
\hline & & *q'atsa & 'new (clothing, goods)' & $\mathrm{A}$ \\
\hline & & *q'atşa & $\begin{array}{l}\text { 'sinner, immoral } \\
\text { person' }\end{array}$ & A \\
\hline \multirow[t]{2}{*}{$\begin{array}{l}\text { *qatspa- } \\
\text { *qašpa- }\end{array}$} & $\begin{array}{l}\text { 'to singe, scrape } \\
\text { surface' }\end{array}$ & *q'aspa- & $\begin{array}{l}\text { 'to singe, scrape } \\
\text { surface' }\end{array}$ & Q \\
\hline & & *qala & 'stone' & A \\
\hline
\end{tabular}


(C2017 by The University of Chicago. All rights reserved.

\begin{tabular}{|c|c|c|c|c|}
\hline$*$ qaKa(ri)- & 'to begin' & $*$ qaKa- & 'to begin' & \\
\hline$* \mathrm{qa} \hat{\mathrm{nu}}$ & 'tongue' & & & $\mathrm{Q}$ \\
\hline \multirow[t]{2}{*}{ *qam } & 'you' & & & $\mathrm{Q}$ \\
\hline & & ${ }^{*} \mathbf{q}^{\text {hana- }}$ & $\begin{array}{l}\text { 'light, to appear, } \\
\text { illuminate, emit light' }\end{array}$ & $\mathrm{A}$ \\
\hline \multirow[t]{4}{*}{ *qantsis } & 'seven' & & & Q \\
\hline & & *q'añu & 'dirty, murky' & $\mathrm{A}$ \\
\hline & & *qhapa- & 'lid, to cover' & $\mathrm{A}$ \\
\hline & & *q qhapaqa & 'powerful, rich' & \\
\hline *qapa(ri)- & 'to shout, yell' & & & \\
\hline \multirow[t]{2}{*}{ *qapi- } & $\begin{array}{l}\text { 'to squeeze out, wring, } \\
\text { milk' }\end{array}$ & *q'api- & 'to squeeze in hands' & \\
\hline & & *qapu- & $\begin{array}{l}\text { 'spinning wheel, to } \\
\text { spin thread' }\end{array}$ & $\mathrm{A}$ \\
\hline *qaqa & 'rock, cliff, crag' & & & \\
\hline *qaqu- & 'to rub, scrub' & & & $\mathrm{Q}$ \\
\hline *qara- & 'to serve food' & & & $\mathrm{Q}$ \\
\hline \multirow[t]{2}{*}{$\begin{array}{l}\text { *qara- } \\
\text { *qa人a- }\end{array}$} & $\begin{array}{l}\text { 'naked, bare, to peel, } \\
\text { strip' }\end{array}$ & *q'ara- & $\begin{array}{l}\text { 'naked, bare, to peel, } \\
\text { strip' }\end{array}$ & \\
\hline & & *qara(ča) & 'scabies' & \\
\hline *qarqu- & $\begin{array}{l}\text { 'to expel, throw out } \\
\text { (person), drive out' }\end{array}$ & & & $\mathrm{Q}$ \\
\hline *qarwa- & $\begin{array}{l}\text { 'yellow, orange, to } \\
\text { turn yellow, to ripen } \\
\text { (e.g., wheat), to } \\
\text { wither' }\end{array}$ & & & \\
\hline \multirow[t]{2}{*}{ *qasa- } & $\begin{array}{l}\text { 'ice, frost, to freeze, be } \\
\text { freezing' }\end{array}$ & & & Q \\
\hline & & *q'asa- & 'to moan, yell' & $\mathrm{A}$ \\
\hline *qasqu & 'chest' & & & Q \\
\hline *qata- & $\begin{array}{l}\text { 'roof, cover, to cover } \\
\text { or shelter' }\end{array}$ & & & \\
\hline \multirow[t]{2}{*}{ *qati- } & $\begin{array}{l}\text { 'to herd, drive } \\
\text { (animals), follow' }\end{array}$ & & & $\mathrm{Q}$ \\
\hline & & ${ }^{*} \mathbf{q}^{\mathrm{h}}$ ati- & 'to cook, be cooked' & $\mathrm{A}$ \\
\hline \multirow[t]{4}{*}{ *qawa- } & 'to look' & & & $\mathrm{Q}$ \\
\hline & & *q'awa & 'gully, ditch, crack' & \\
\hline & & *q'awi- & 'to chew, bite' & $\mathrm{A}$ \\
\hline & & *qawra & 'llama' & $\mathrm{A}$ \\
\hline *qaya- & $\begin{array}{l}\text { 'to yell, call out, call } \\
\text { together' }\end{array}$ & & & Q \\
\hline
\end{tabular}


(C2017 by The University of Chicago. All rights reserved.

\begin{tabular}{|c|c|c|c|c|}
\hline & & *q'ayma & 'tasteless (food)' & \\
\hline $\begin{array}{l}\text { *qayna } \\
\text { *qanyan }\end{array}$ & $\begin{array}{l}\text { 'yesterday, previous, } \\
\text { past' }\end{array}$ & & & Q \\
\hline *qitsa & 'diarrhea' & & & Q \\
\hline *qitsu- & $\begin{array}{l}\text { 'to take away, } \\
\text { remove' }\end{array}$ & & & Q \\
\hline \multirow[t]{2}{*}{ *qiKa } & 'lazy' & & & Q \\
\hline & & ${ }^{*} \mathbf{q}^{\text {hiKa }}$ & 'ashes' & A \\
\hline *qiKqa- & 'to write, draw' & *qiKqa- & 'to write' & \\
\hline *qimi- & $\begin{array}{l}\text { 'to support, prop up, } \\
\text { hold up' }\end{array}$ & & & \\
\hline \multirow[t]{2}{*}{ *qintşa } & $\begin{array}{l}\text { 'corral, fenced } \\
\text { enclosure' }\end{array}$ & *qintsa & $\begin{array}{l}\text { 'corral, fenced } \\
\text { enclosure' }\end{array}$ & \\
\hline & & ${ }^{*} \mathbf{q}^{\mathrm{h}}$ insa- & $\begin{array}{l}\text { 'to blow nose, to be } \\
\text { face down in the } \\
\text { water' }\end{array}$ & A \\
\hline \multirow[t]{2}{*}{ *qinti- } & 'to shrink, contract' & & & Q \\
\hline & & *qiñwa & 'tree species' & \\
\hline *qipa & $\begin{array}{l}\text { 'behind (space), after } \\
\text { (time)' }\end{array}$ & & & Q \\
\hline \multirow[t]{3}{*}{ *qipi- } & $\begin{array}{l}\text { 'bundle carried on } \\
\text { back, to carry on back' }\end{array}$ & & & Q \\
\hline & & *qipu & 'thorn, thorny plant' & A \\
\hline & & $*$ q'iri & 'wound, scab' & \\
\hline *qiru & $\begin{array}{l}\text { 'wood, trunk, wooden } \\
\text { cup' }\end{array}$ & $* q^{\prime}$ iru & $\begin{array}{l}\text { 'maguey plant, type of } \\
\text { wood, drinking cup' }\end{array}$ & \\
\hline \multirow[t]{2}{*}{ *qisa } & 'nest' & & & Q \\
\hline & & *qisa & $\begin{array}{l}\text { 'hopeless, abandoned, } \\
\text { dejected' }\end{array}$ & A \\
\hline *qišpi- & $\begin{array}{l}\text { 'to be safe, be saved, } \\
\text { escape, be born' }\end{array}$ & & & Q \\
\hline *qišpi & 'crystal, glass' & ${ }^{*} \mathrm{q}^{\mathrm{h}}$ ispi & 'crystal, glass' & Q \\
\hline *qiwa & 'fodder, pasture grass' & & & \\
\hline *qiwi- & 'to twist apart, sprain' & & & Q \\
\hline$* q u-$ & 'to give' & & & Q \\
\hline *qutşa & 'lake' & *qutsa & 'lake, pool' & \\
\hline *qutspa- & $\begin{array}{l}\text { 'to roll around, to } \\
\text { roll' }\end{array}$ & & & Q \\
\hline \multirow[t]{2}{*}{ *quSi- } & $\begin{array}{l}\text { 'to cover embers to } \\
\text { maintain fire' }\end{array}$ & & & Q \\
\hline & & *quKqi & 'silver, money, coin' & \\
\hline
\end{tabular}


(C2017 by The University of Chicago. All rights reserved.

\begin{tabular}{|c|c|c|c|c|}
\hline$*$ quKu- & $\begin{array}{l}\text { 'to die off, extinguish, } \\
\text { run out' }\end{array}$ & & & Q \\
\hline & & ${ }^{*} \mathbf{q}^{\mathrm{h}} \mathbf{u m a -}$ & 'to hug, brood' & $\mathrm{A}$ \\
\hline & & *qumpi- & 'to sew, embroider' & $\mathrm{A}$ \\
\hline \multirow[t]{2}{*}{ *qunču } & 'sediment, grounds' & *qunču & 'sediment, grounds' & \\
\hline & & *quntsa & $\begin{array}{l}\text { 'brother of man, } \\
\text { companion' }\end{array}$ & A \\
\hline *qunqa- & 'to forget' & & & $\mathrm{Q}$ \\
\hline *qunqur & 'knee' & $\begin{array}{l}\text { *qunqura } \\
* \text { qunquri } \\
* \text { qunquru }\end{array}$ & 'knee' & $\mathrm{Q}$ \\
\hline \multirow{3}{*}{$\begin{array}{l}* \text { quñu- } \\
{ }^{*} \text { quñi- }\end{array}$} & 'hot, to heat' & & & \\
\hline & & *ququ & $\begin{array}{l}\text { 'snack, provisions for } \\
\text { journey' }\end{array}$ & $\mathrm{A}$ \\
\hline & & *q'urawa & 'intestines, slingshot' & $\mathrm{A}$ \\
\hline \multirow[t]{2}{*}{ *quri } & 'gold' & & & \\
\hline & & *qurpa & $\begin{array}{l}\text { 'furrow, ditch, } \\
\text { boundary' }\end{array}$ & A \\
\hline \multirow[t]{2}{*}{ *quru } & 'blunted, cropped' & & & $\mathrm{Q}$ \\
\hline & & $* q^{h}$ uru- & 'to snore' & \\
\hline *quruta & 'testicle' & & & \\
\hline *qusa & 'husband' & & & Q \\
\hline *qutu- & $\begin{array}{l}\text { 'mound, group, bunch, } \\
\text { tumor, to gather, pile } \\
\text { up' }\end{array}$ & $*$ qutu & $\begin{array}{l}\text { 'mound, group, bunch, } \\
\text { tumor' }\end{array}$ & \\
\hline \multirow[t]{2}{*}{ *quyNur } & 'a particular star' & & & $\mathrm{Q}$ \\
\hline & & *quyru & 'cloudy eye' & \\
\hline *raka & 'vagina' & & & Q \\
\hline *raki- & $\begin{array}{l}\text { 'to separate, sort, } \\
\text { select, hand out' }\end{array}$ & *laki- & $\begin{array}{l}\text { 'to separate, sort, select, } \\
\text { hand out' }\end{array}$ & \\
\hline *rakta & 'thick' & & & Q \\
\hline *ranti- & $\begin{array}{l}\text { 'to exchange, } \\
\text { substitute, replace' }\end{array}$ & & & $\mathrm{Q}$ \\
\hline *rapra & 'wing, leaf' & & & $\mathrm{Q}$ \\
\hline *raqra- & $\begin{array}{l}\text { 'crack, ditch, trench, to } \\
\text { crack, split' }\end{array}$ & & & Q \\
\hline *rata- & $\begin{array}{l}\text { 'to land, fall, stick in } \\
\text { a place' }\end{array}$ & & & Q \\
\hline *rawra- & 'to burn (intrans.)' & & & Q \\
\hline *ri- & 'to go' & & & Q \\
\hline
\end{tabular}




\begin{tabular}{|c|c|c|c|c|}
\hline $\begin{array}{l}\text { *rika- } \\
\text { *riku- }\end{array}$ & 'to see' & & & Q \\
\hline *riktsa- & 'to wake up' & & & $\mathrm{Q}$ \\
\hline *rikra & 'upper arm, wing' & & & $\mathrm{Q}$ \\
\hline *rima- & 'to speak' & & & $\mathrm{Q}$ \\
\hline *rinri & 'ear' & & & Q \\
\hline *riqsi- & $\begin{array}{l}\text { 'to know, be } \\
\text { acquainted with' }\end{array}$ & & & Q \\
\hline *rumi & 'stone' & & & $\mathrm{Q}$ \\
\hline *runa & 'person, human' & & & Q \\
\hline *runku & 'bag, sack' & & & \\
\hline *runtu & 'egg, hailstone' & & & Q \\
\hline *rupa- & $\begin{array}{l}\text { 'hot, heat, to burn, } \\
\text { shine, be hot' }\end{array}$ & *lup'i & $\begin{array}{l}\text { 'sunlight, heat from } \\
\text { sun' }\end{array}$ & \\
\hline *rura- & 'to do, make, work' & *lura- & 'to do, make, work' & \\
\hline *ruru & $\begin{array}{l}\text { 'round thing, pit, egg, } \\
\text { testicle, kidney' }\end{array}$ & & & \\
\hline *rutu- & 'to shear, cut hair' & & & Q \\
\hline \multirow[t]{2}{*}{ *(r)uyru } & 'round' & & & Q \\
\hline & & $*$ sa- & 'to sow' & $\mathrm{A}$ \\
\hline \multirow[t]{2}{*}{ *satsa } & 'bush, tree, forest' & & & $\mathrm{Q}$ \\
\hline & & *sak'a- & $\begin{array}{l}\text { 'to beat, hit with an } \\
\text { object' }\end{array}$ & $\mathrm{A}$ \\
\hline *saksa- & $\begin{array}{l}\text { 'to swell, be full of } \\
\text { food' }\end{array}$ & & & Q \\
\hline *saKqa & $\begin{array}{l}\text { 'high grasslands, } \\
\text { person from the high } \\
\text { grasslands, uncultured } \\
\text { person' (N.B. } \\
\text { offensive) }\end{array}$ & *šaイqa & $\begin{array}{l}\text { 'high grasslands, person } \\
\text { from the high } \\
\text { grasslands, uncultured } \\
\text { person' (N.B. offensive) }\end{array}$ & \\
\hline \multirow[t]{2}{*}{ *sama- } & 'to breathe, rest' & *sama- & 'to breathe, rest' & \\
\hline & & *sama & 'back, shoulder' & A \\
\hline *sapa & 'alone, each' & & & $\mathrm{Q}$ \\
\hline *sapi & 'root' & & & \\
\hline *saqi- & $\begin{array}{l}\text { 'to leave behind, } \\
\text { abandon' }\end{array}$ & & & $\mathrm{Q}$ \\
\hline *saqma- & 'to hit, punch' & & & $\mathrm{Q}$ \\
\hline$*_{\text {sara }}$ & 'corn' & & & Q \\
\hline *saru- & 'to step on' & $*$ saru- & 'to stand up, step on' & \\
\hline$*$ sasa & 'difficult' & & & \\
\hline *sati- & 'to insert' & & & Q \\
\hline
\end{tabular}


(C2017 by The University of Chicago. All rights reserved.

\begin{tabular}{|c|c|c|c|c|}
\hline *sawna & $\begin{array}{l}\text { 'pillow, head } \\
\text { support' }\end{array}$ & & & Q \\
\hline & & *saya- & 'to say' & $\mathrm{A}$ \\
\hline & & $*_{\text {sayu- }}$ & 'to weave' & $\mathrm{A}$ \\
\hline & & *sits'i- & 'to rip apart' & $\mathrm{A}$ \\
\hline & & ${ }^{*}$ sikk $^{\mathrm{h}} \mathrm{a}-$ & 'to yank, pull out' & A \\
\hline \multirow[t]{2}{*}{$*_{\text {siki }}$} & 'butt, base' & & & $\mathrm{Q}$ \\
\hline & & *siKp'i & 'peel, tree bark' & \\
\hline *sintsi- & $\begin{array}{l}\text { 'strong, brave, to gain } \\
\text { strength' }\end{array}$ & & & \\
\hline$*_{\text {sinqa }}$ & 'nose' & & & $\mathrm{Q}$ \\
\hline$*$ sipi- & $\begin{array}{l}\text { 'to snap neck, yank, } \\
\text { slaughter' }\end{array}$ & & & \\
\hline$*_{\text {sipu- }} \sim *^{\text {šipu- }}$ & $\begin{array}{l}\text { 'wrinkle, to wrinkle, } \\
\text { furrow, pleat' }\end{array}$ & & & \\
\hline *siqa- & $\begin{array}{l}\text { 'to climb, rise, } \\
\text { ascend' }\end{array}$ & & & $\mathrm{Q}$ \\
\hline \multirow[t]{2}{*}{ *sira- } & 'to sew' & & & Q \\
\hline & & *sira- & 'fart, to fart' & $\mathrm{A}$ \\
\hline *sisa- & 'flower, to blossom' & & & Q \\
\hline *sutska- & 'to slide, slip' & & & $\mathrm{Q}$ \\
\hline \multirow[t]{2}{*}{ *sutsu- } & 'to slide, slip' & & & \\
\hline & & $*_{\text {sunaqi }}$ & $\begin{array}{l}\text { 'zenith, hair part, } \\
\text { fontanelle' }\end{array}$ & A \\
\hline *supay & 'evil spirit, demon' & & & $\mathrm{Q}$ \\
\hline *supi- & 'fart, to fart' & & & Q \\
\hline \multirow[t]{2}{*}{ *suqta } & 'six' & *suqta & 'six' & Q \\
\hline & & *suq'u & 'corn husk' & A \\
\hline *surqu- & $\begin{array}{l}\text { 'to remove, take out, } \\
\text { extract' }\end{array}$ & & & Q \\
\hline *susu(nka)- & 'to become numb' & $*^{*}$ susunk ${ }^{\mathrm{h}} \mathrm{a}-$ & 'to become numb' & \\
\hline$*_{\text {suwa- }}$ & 'thief, to steal' & & & $\mathrm{Q}$ \\
\hline \multirow[t]{3}{*}{ *šamu- } & 'to come' & & & $\mathrm{Q}$ \\
\hline & & *šanq'a & 'throat, larynx, sinus' & \\
\hline & & *šaqša & 'ragged, frayed, tousled' & $\mathrm{Q}$ \\
\hline *ร̌awa- & $\begin{array}{l}\text { 'to tie together, get } \\
\text { married' }\end{array}$ & & & $\mathrm{Q}$ \\
\hline *šaya- & $\begin{array}{l}\text { 'to stand, stop, be } \\
\text { upright' }\end{array}$ & *saya- & $\begin{array}{l}\text { 'to stand, stop, be } \\
\text { upright' }\end{array}$ & \\
\hline *šikwa- & 'to broadcast seeds' & & & $\mathrm{Q}$ \\
\hline
\end{tabular}


(C2017 by The University of Chicago. All rights reserved.

\begin{tabular}{|c|c|c|c|c|}
\hline$*$ ši $\hat{\Lambda} \mathrm{u}$ & 'nail, claw' & $*$ ši $\hat{\Lambda} \mathrm{u}$ & 'nail, claw' & \\
\hline *šimi & 'mouth, language' & & & \\
\hline *šimpa- & 'braid, to braid' & & & $Q$ \\
\hline *šinka- & $\begin{array}{l}\text { 'drunk, tipsy, to get } \\
\text { drunk' }\end{array}$ & & & \\
\hline \multirow[t]{3}{*}{$\begin{array}{l}\text { *šipaš } \sim \text { *šipas } \\
\sim *^{*} \operatorname{sipaš~}\end{array}$} & 'girl' & & & Q \\
\hline & & *šip'i & 'bush species' & $\mathrm{A}$ \\
\hline & & *šiq'i- & $\begin{array}{l}\text { 'line, row, to make } \\
\text { lines' }\end{array}$ & $\mathrm{A}$ \\
\hline *šiqšsi- & 'itch, to itch' & & & $\mathrm{Q}$ \\
\hline *šuka- & 'to whistle' & & & $\mathrm{Q}$ \\
\hline$*_{\text {šuKa- }}$ & 'dew, to form dew' & & & \\
\hline *šuKka & $\begin{array}{l}\text { 'younger, younger } \\
\text { brother' }\end{array}$ & $*$ šuKk $\mathrm{k}^{\mathrm{h}} \mathrm{a}$ & $\begin{array}{l}\text { 'younger, younger } \\
\text { brother' }\end{array}$ & \\
\hline *šuKu- & $\begin{array}{l}\text { 'fetus, to abort, } \\
\text { miscarry' }\end{array}$ & $*$ šuKu & 'fetus' & \\
\hline *šumaq & 'beautiful, good' & *šuma & 'beautiful, good' & \\
\hline *šunqu & 'heart' & & & $\mathrm{Q}$ \\
\hline \multirow[t]{2}{*}{ *šuqu- } & 'to suck, slurp' & & & Q \\
\hline & & *šuta & 'potato variety' & $\mathrm{A}$ \\
\hline$*$ šuti $\sim *_{\text {suti }}$ & 'name' & *šuti & 'name' & \\
\hline *šutu- & 'drop, to drip' & & & $\mathrm{Q}$ \\
\hline *šuya- & 'to wait' & & & Q \\
\hline *šuyšu- & 'to strain, sift, filter' & & & $\mathrm{Q}$ \\
\hline *taka- & $\begin{array}{l}\text { 'to punch, knock, hit } \\
\text { with hard object' }\end{array}$ & & & Q \\
\hline$*$ taki- & $\begin{array}{l}\text { 'song, to sing, to } \\
\text { dance' }\end{array}$ & & & Q \\
\hline *takKa & 'plow' & & & $\mathrm{Q}$ \\
\hline *takša & 'small, short' & & & $\mathrm{Q}$ \\
\hline$* \operatorname{ta} \hat{\mathrm{i}}-$ & 'to pour, pour out' & & & Q \\
\hline *tampa & $\begin{array}{l}\text { 'tangled, disheveled, } \\
\text { unkempt' }\end{array}$ & *ts'ampa & $\begin{array}{l}\text { 'tangled, disheveled, } \\
\text { unkempt' }\end{array}$ & \\
\hline *tanqa- & 'to push' & & & $\mathrm{Q}$ \\
\hline \multirow[t]{2}{*}{$*$ tanta } & 'bread' & $*$ t'anta & 'bread' & \\
\hline & & *t'apra & 'wool' & \\
\hline *tapši- & $\begin{array}{l}\text { 'to shake up, shake } \\
\text { out' }\end{array}$ & & & Q \\
\hline *tapu- & 'to ask' & & & $\mathrm{Q}$ \\
\hline
\end{tabular}


(C2017 by The University of Chicago. All rights reserved.

\begin{tabular}{|c|c|c|c|c|}
\hline *tapya- & 'omen, to prophesy' & & & Q \\
\hline & & $*$ thaqa- & $\begin{array}{l}\text { 'to search for, } \\
\text { rummage' }\end{array}$ & \\
\hline *taq Ka- & 'slap, to slap, applaud' & $* \operatorname{taq} \Lambda \mathrm{i}-$ & 'slap, to slap, applaud' & Q \\
\hline *taqša- & 'to launder' & & & $\mathrm{Q}$ \\
\hline *tari- & 'to find, get, meet' & & & Q \\
\hline *tarpu- & 'to sow seeds' & & & Q \\
\hline *taruka & 'deer species' & *taruka & 'deer species' & \\
\hline *tawna & 'walking cane' & & & Q \\
\hline \multirow[t]{3}{*}{$*$ tawri *tarwi } & 'lupine' & & & $\mathrm{Q}$ \\
\hline & & $*$ tika & 'adobe, mold' & \\
\hline & & *t'iki- & 'to grind, mix' & A \\
\hline *tikra- & 'to overturn' & & & $\mathrm{Q}$ \\
\hline *tikti & 'wart' & & & $\mathrm{Q}$ \\
\hline \multirow[t]{2}{*}{ *timpu- } & $\begin{array}{l}\text { 'boiled, to boil } \\
\text { (intrans.)' }\end{array}$ & & & \\
\hline & & *t'impu- & $\begin{array}{l}\text { 'to pin up, roll up } \\
\text { fabric' }\end{array}$ & A \\
\hline *tinki- & $\begin{array}{l}\text { 'to join (trans.), } \\
\text { unite, bring together' }\end{array}$ & & & Q \\
\hline *tinya & 'small drum' & & & $\mathrm{Q}$ \\
\hline$*$ tipi- & 'to pick apart, cut up' & & & Q \\
\hline \multirow[t]{3}{*}{ *tipši- } & 'to pinch' & & & Q \\
\hline & & $*$ tira & 'crib' & A \\
\hline & & $* t$ 'iri- & 'to pin, stitch, tack' & A \\
\hline \multirow[t]{3}{*}{$*$ tiya- *taya- } & 'to sit' & & & Q \\
\hline & & $*$ tukru & 'cane, staff' & $\mathrm{Q}$ \\
\hline & & *tuksa- & 'to stink' & \\
\hline *tukši- & $\begin{array}{l}\text { 'to stab, prick, } \\
\text { puncture' }\end{array}$ & & & Q \\
\hline *tuku- & $\begin{array}{l}\text { 'to finish, become, } \\
\text { pretend' }\end{array}$ & *tuku- & $\begin{array}{l}\text { 'to finish, become, } \\
\text { pretend' }\end{array}$ & \\
\hline *tukuy & 'all' & & & Q \\
\hline \multirow[t]{2}{*}{ *tuKpa } & $\begin{array}{l}\text { 'fireplace, hearth, } \\
\text { stove' }\end{array}$ & & & Q \\
\hline & & *tuKqa & 'son-in-law' & A \\
\hline$* \mathrm{tuKu}$ & 'bone' & & & \\
\hline *tumpa- & $\begin{array}{l}\text { 'to testify, accuse, } \\
\text { blame, slander' }\end{array}$ & *tumpa- & $\begin{array}{l}\text { 'to testify, accuse, } \\
\text { blame, slander' }\end{array}$ & \\
\hline
\end{tabular}




\begin{tabular}{|c|c|c|c|c|}
\hline & & $\begin{array}{l}* \text { t'uni- } \\
*_{\text {th }} \text { uni- }\end{array}$ & 'to collapse, crumble' & \\
\hline & & $* \mathrm{t}^{\mathrm{h}} \mathrm{u}(\mathrm{n}) \mathrm{ku}-$ & $\begin{array}{l}\text { 'to shuffle, skip, } \\
\text { stumble, hop' }\end{array}$ & A \\
\hline & & *tunqu & 'corn' & \\
\hline *tunquri & 'throat' & & & Q \\
\hline *tupu- & $\begin{array}{l}\text { 'measurement, to } \\
\text { measure (size, } \\
\text { quantity, or distance)' }\end{array}$ & *tupu- & $\begin{array}{l}\text { 'measurement, to } \\
\text { measure (size, quantity, } \\
\text { or distance)' }\end{array}$ & \\
\hline *tuqa- & $\begin{array}{l}\text { 'spit, saliva, to spit, } \\
\text { cough up' }\end{array}$ & & & Q \\
\hline \multirow[t]{4}{*}{$*$ turi } & 'brother of woman' & & & Q \\
\hline & & $*$ turu & 'blunt, rounded' & A \\
\hline & & *t'uru- & $\begin{array}{l}\text { 'to gnaw, chew, crunch } \\
\text { in teeth' }\end{array}$ & A \\
\hline & & $* \mathrm{t}^{\mathrm{h}} \mathrm{usa}-$ & 'to spit' & A \\
\hline *tušu- & 'to dance' & & & Q \\
\hline$*$ tuta & 'night, darkness' & & & \\
\hline *uču & 'chili pepper' & & & \\
\hline \multirow{2}{*}{ *učuy *učuk } & 'small' & & & Q \\
\hline & & *utsa- & $\begin{array}{l}\text { 'porridge, mush, to } \\
\text { gulp' }\end{array}$ & A \\
\hline *utsku- & $\begin{array}{l}\text { 'hole, to dig, make a } \\
\text { hole' }\end{array}$ & & & Q \\
\hline \multirow[t]{4}{*}{ *utspa } & 'ashes' & & & Q \\
\hline & & *uka & 'that' & $\mathrm{A}$ \\
\hline & & *uKa & $\begin{array}{l}\text { 'cooked, overcooked, } \\
\text { or spoiled potato' }\end{array}$ & $\mathrm{A}$ \\
\hline & & $* \mathbf{u} \mathbf{K a}-$ & 'to see, look, watch' & A \\
\hline *uKuku & 'olluco (tuber species)' & & & \\
\hline \multirow[t]{2}{*}{ *uma } & 'head' & & & Q \\
\hline & & *uma- & 'water, to drink' & $\mathrm{A}$ \\
\hline *una- & $\begin{array}{l}\text { 'to delay, be a long } \\
\text { time' }\end{array}$ & & & Q \\
\hline *uña & $\begin{array}{l}\text { 'calf, lamb, juvenile } \\
\text { domesticated animal' }\end{array}$ & & & Q \\
\hline *upa & $\begin{array}{l}\text { 'mute, quiet, deaf, } \\
\text { stupid' }\end{array}$ & & & \\
\hline *upya- & 'to drink' & & & Q \\
\hline *uqa & 'oca (kind of tuber)' & & & Q \\
\hline *uqi & 'grey, brown' & *uqi & 'grey, brown' & \\
\hline
\end{tabular}


(C2017 by The University of Chicago. All rights reserved.

\begin{tabular}{|c|c|c|c|c|}
\hline *uqKa- & $\begin{array}{l}\text { 'to embrace, incubate, } \\
\text { warm with body heat' }\end{array}$ & & & Q \\
\hline & & $* \mathrm{uqu}-$ & $\begin{array}{l}\text { 'to swallow, gobble up, } \\
\text { devour' }\end{array}$ & $\mathrm{A}$ \\
\hline \multirow[t]{4}{*}{ *ura } & 'below, down' & & & Q \\
\hline & & *uraqi & 'earth, soil, land' & A \\
\hline & & *urk ${ }^{\mathrm{h}} \mathbf{u}$ & 'female garment' & $\mathrm{A}$ \\
\hline & & ${ }^{*} \mathbf{u r p}^{\mathrm{h}} \mathbf{u}$ & 'cloud, mist, fog' & $\mathrm{A}$ \\
\hline *urqu & 'mountain' & & & \\
\hline \multirow[t]{2}{*}{$*$ urqu $\sim * u K q u$} & 'male' & *urqu & 'male' & \\
\hline & & $* \mathbf{u r u}$ & 'day' & A \\
\hline \multirow[t]{2}{*}{ *usa- } & 'louse, to remove lice' & & & Q \\
\hline & & *usu- & 'to become sick' & A \\
\hline \multirow[t]{3}{*}{ *usya- } & $\begin{array}{l}\text { 'to clear up } \\
\text { (weather)' }\end{array}$ & & & $\mathrm{Q}$ \\
\hline & & $*$ uta & 'house, dwelling' & A \\
\hline & & *uta- & 'to be, exist, live, sit' & $\mathrm{A}$ \\
\hline *utku & 'cotton' & & & Q \\
\hline \multirow[t]{2}{*}{ *uya(ri)- } & 'to hear, listen' & & & $\mathrm{Q}$ \\
\hline & & *uyu & 'corral' & A \\
\hline *uywa- & $\begin{array}{l}\text { 'domestic animal, to } \\
\text { raise an animal' }\end{array}$ & *uywa- & $\begin{array}{l}\text { 'domestic animal, to } \\
\text { raise an animal' }\end{array}$ & \\
\hline *watsa- & $\begin{array}{l}\text { 'to give birth, lay } \\
\text { eggs' }\end{array}$ & & & Q \\
\hline *watsi- & $\begin{array}{l}\text { 'pole, lance, stick, to } \\
\text { poke, sting, stab' }\end{array}$ & & & Q \\
\hline \multirow[t]{2}{*}{ *waka- } & $\begin{array}{l}\text { 'crack, cleft, special } \\
\text { object or place, sacred, } \\
\text { dangerous, to change } \\
\text { state, turn wild' }\end{array}$ & & & Q \\
\hline & & *wak'a & 'belt, sash' & \\
\hline *wakča & 'poor, orphan' & *wakča & 'poor, orphan' & Q \\
\hline \multirow[t]{2}{*}{ *wakin } & 'some, other' & & & $\mathrm{Q}$ \\
\hline & & *wala- & 'to run' & \\
\hline${ }^{*}$ wa $\hat{p} a^{7}$ & 'bird species' & ${ }^{*}$ wa $\hat{\mathrm{p}} \mathrm{a}$ & 'bird species' & Q \\
\hline *waKqa- & $\begin{array}{l}\text { 'necklace, pendant, to } \\
\text { hang around the neck' }\end{array}$ & *waKqa & 'necklace, necktie' & Q \\
\hline *wampu- & $\begin{array}{l}\text { 'raft, to float, navigate } \\
\text { boat, swim' }\end{array}$ & & & Q \\
\hline *wamra & 'child' & & & Q \\
\hline
\end{tabular}


(C2017 by The University of Chicago. All rights reserved.

\begin{tabular}{|c|c|c|c|c|}
\hline *wana- & $\begin{array}{l}\text { 'repentance, fear, to } \\
\text { repent, reform, amend, } \\
\text { fear' }\end{array}$ & *wani- & $\begin{array}{l}\text { 'repentance, fear, to } \\
\text { repent, reform, amend, } \\
\text { fear' }\end{array}$ & Q \\
\hline & & *wankara & 'drum type' & $\mathrm{Q}$ \\
\hline *wanku- & $\begin{array}{l}\text { 'to wrap, bundle, } \\
\text { bandage' }\end{array}$ & & & $\mathrm{Q}$ \\
\hline *wantu- & $\begin{array}{l}\text { 'to carry among two or } \\
\text { more people' }\end{array}$ & & & $\mathrm{Q}$ \\
\hline *wanu & 'guano' & $*_{\text {wanu }}$ & 'guano' & $\mathrm{Q}$ \\
\hline *wañu- & $\begin{array}{l}\text { 'to die, wilt, lose } \\
\text { consciousness, pass } \\
\text { away' }\end{array}$ & & & $\mathrm{Q}$ \\
\hline \multirow[t]{2}{*}{ *waqa- } & 'to cry, wail' & & & $\mathrm{Q}$ \\
\hline & & $\begin{array}{l}*_{\text {waqi- }} \sim \\
{ }^{*} \text { waki- }\end{array}$ & $\begin{array}{l}\text { 'to coordinate action or } \\
\text { labor, to allocate } \\
\text { responsibility and } \\
\text { profit' }\end{array}$ & Q \\
\hline *waqSi- & $\begin{array}{l}\text { 'to slip off, go astray, } \\
\text { become corrupted' }\end{array}$ & & & $\mathrm{Q}$ \\
\hline *waqra- & 'horn, to gore' & *waqra & 'horn' & $\mathrm{Q}$ \\
\hline *waqta & $\begin{array}{l}\text { 'flank, side (body, } \\
\text { hill), ribs' }\end{array}$ & & & Q \\
\hline *waraka & 'sling, slingshot' & & & $\mathrm{Q}$ \\
\hline *waranqa & 'thousand' & $*_{\text {waranqa }}$ & 'thousand' & Q \\
\hline$*_{\text {warku- }}$ & $\begin{array}{l}\text { 'to hang up, to be hung } \\
\text { up' }\end{array}$ & & & $\mathrm{Q}$ \\
\hline *warmi & 'woman, wife' & *warmi & 'woman, wife' & $\mathrm{Q}$ \\
\hline *wasi & 'house' & & & Q \\
\hline *waska & 'rope' & & & $\mathrm{Q}$ \\
\hline \multirow[t]{2}{*}{ *waša } & 'back (body part)' & & & Q \\
\hline & & *waša & 'place, desolate place' & $\mathrm{Q}$ \\
\hline *wata & 'year' & & & Q \\
\hline \multirow[t]{2}{*}{ *wata- } & 'to tie, repair' & *wata- & 'to mend, darn, patch' & Q \\
\hline & & *wat'a- & 'to extend legs, kick' & $\mathrm{Q}$ \\
\hline *watu- & $\begin{array}{l}\text { 'to divine, visit, miss } \\
\text { a person' }\end{array}$ & & & Q \\
\hline$*_{\text {watu }}$ & 'cord, strap' & & & $\mathrm{Q}$ \\
\hline *wawa & $\begin{array}{l}\text { 'child (of mother), } \\
\text { baby' }\end{array}$ & *wawa & $\begin{array}{l}\text { 'child (of mother), } \\
\text { baby' }\end{array}$ & Q \\
\hline${ }^{*}$ wawqi & 'brother of man' & & & $\mathrm{Q}$ \\
\hline
\end{tabular}


(C2017 by The University of Chicago. All rights reserved.

\begin{tabular}{|c|c|c|c|c|}
\hline *wayka- & $\begin{array}{l}\text { 'to collaborate, gang } \\
\text { up on' }\end{array}$ & *wayka- & $\begin{array}{l}\text { 'to grab, gang up on, } \\
\text { compete' }\end{array}$ & Q \\
\hline *wayKa & $\begin{array}{l}\text { 'meadow, prairie, } \\
\text { grass' }\end{array}$ & & & $\mathrm{Q}$ \\
\hline *wayKu- & $\begin{array}{l}\text { 'to love, express } \\
\text { affection, caress' }\end{array}$ & & & Q \\
\hline \multirow[t]{2}{*}{ *wayna } & 'young man, lover' & *wayna & 'young man, lover' & $\mathrm{Q}$ \\
\hline & & *waynu & 'dance type, to dance' & $\mathrm{Q}$ \\
\hline *wayta & 'flower' & & & $\mathrm{Q}$ \\
\hline *wayunka & $\begin{array}{l}\text { 'ear of corn hung up } \\
\text { to dry' }\end{array}$ & & & Q \\
\hline \multirow[t]{3}{*}{$\begin{array}{l}*_{\text {waywa }} \sim \\
*_{\text {wayra }} \\
\end{array}$} & 'wind' & $\begin{array}{l}*_{\text {waywa }} \\
*_{\text {wayra }}\end{array}$ & 'wind' & Q \\
\hline & & ${ }^{*}$ wič'inka & 'tail' & $\mathrm{Q}$ \\
\hline & & *wič'u & 'tibia, radius, thin' & $\mathrm{Q}$ \\
\hline \multirow[t]{3}{*}{ *witsqa- } & 'to close, enclose' & & & $\mathrm{Q}$ \\
\hline & & *wihira & 'drool, saliva' & \\
\hline & & *wik'a- & 'to rip, pull apart' & Q \\
\hline *wika(pa)- & 'to throw into the air' & & & $\mathrm{Q}$ \\
\hline$*_{\text {wiksa }}$ & 'belly, abdomen' & & & Q \\
\hline$*_{\text {wiksu }}$ & $\begin{array}{l}\text { 'twisted, cross-eyed, } \\
\text { bowlegged' }\end{array}$ & & & $\mathrm{Q}$ \\
\hline *wiKa- & 'to tell, inform' & & & $\mathrm{Q}$ \\
\hline \multirow[t]{2}{*}{ *wiKka } & 'grandchild, idol' & & & Q \\
\hline & & $*_{\text {winku- }}$ & $\begin{array}{l}\text { 'to lie down, lean, } \\
\text { crouch' }\end{array}$ & Q \\
\hline *wiña- & $\begin{array}{l}\text { 'to grow, sprout, } \\
\text { develop, increase' }\end{array}$ & & & Q \\
\hline$*_{\text {wiqi }}$ & 'tear, teardrop' & & & $\mathrm{Q}$ \\
\hline$*_{\text {wiqru }}$ & $\begin{array}{l}\text { 'lame, with an injured } \\
\text { foot, bowlegged, } \\
\text { twisted' }\end{array}$ & *wiqru & $\begin{array}{l}\text { 'lame, with an injured } \\
\text { foot, bowlegged, } \\
\text { twisted, with a crick in } \\
\text { the neck' }\end{array}$ & $\mathrm{Q}$ \\
\hline *wira & 'fat, grease' & $*_{\text {wila }}$ & 'blood' & $\mathrm{Q}$ \\
\hline *wiraquča & 'Andean deity' & & & Q \\
\hline *wirpa & 'lip' & & & $\mathrm{Q}$ \\
\hline \multirow[t]{2}{*}{$*_{\text {wiru }}$} & 'cane, reed' & $*_{\text {wiru }}$ & 'cane, stalk' & $\mathrm{Q}$ \\
\hline & & *wisk'ača & 'rodent species' & $\mathrm{Q}$ \\
\hline *wiši- & $\begin{array}{l}\text { 'to pour, collect, } \\
\text { transfer liquid or } \\
\text { grains' }\end{array}$ & & & Q \\
\hline
\end{tabular}


(C2017 by The University of Chicago. All rights reserved.

\begin{tabular}{|c|c|c|c|c|}
\hline${ }^{*}$ wiš $\Lambda$ a & 'ladle' & ${ }^{*}$ wiš $\Lambda$ a & 'ladle' & Q \\
\hline \multirow[t]{2}{*}{ *wištu- } & $\begin{array}{l}\text { 'twisted, crippled, to } \\
\text { hobble, limp' }\end{array}$ & & & Q \\
\hline & & $*^{*}$ with $^{\mathrm{h}} \mathrm{u}$ & 'cropped tail' & Q \\
\hline *yatsa- & $\begin{array}{l}\text { 'to know (facts, how } \\
\text { to), learn, reside' }\end{array}$ & *yati- & $\begin{array}{l}\text { 'to know (facts, how } \\
\text { to), learn, reside' }\end{array}$ & Q \\
\hline *yaku & 'water' & & & Q \\
\hline *yamta & 'firewood' & & & $\mathrm{Q}$ \\
\hline *yana & 'black' & $*$ yana & 'black' & Q \\
\hline *yana(pa)- & 'to help, accompany' & *yana & 'companion, servant' & $\mathrm{Q}$ \\
\hline *yanqa & 'in vain, for no reason' & $\begin{array}{l}* \text { yanq }^{\mathrm{h}} \mathrm{a} \sim \\
\text { *ñanq } \\
\text { ña }\end{array}$ & $\begin{array}{l}\text { 'in vain, for no reason; } \\
\text { devil, adversary' }\end{array}$ & Q \\
\hline *yanu- & 'to cook, stew' & & & Q \\
\hline \multirow[t]{3}{*}{ *уара- } & $\begin{array}{l}\text { 'a bit more, to add a } \\
\text { bit more, repeat' }\end{array}$ & *yapa- & $\begin{array}{l}\text { 'a bit more, to add a bit } \\
\text { more' }\end{array}$ & $\mathrm{Q}$ \\
\hline & & *yapu & 'agricultural plot' & Q \\
\hline & & ${ }^{*} \operatorname{yaq}^{\mathrm{h}} \mathbf{a}$ & 'other, different' & \\
\hline *yawar & 'blood' & & & Q \\
\hline *yaya & 'father' & & & Q \\
\hline *yayku- & 'to enter' & & & $\mathrm{Q}$ \\
\hline *yunka & $\begin{array}{l}\text { 'lowlands east or west } \\
\text { of the Andes' }\end{array}$ & & & $\mathrm{Q}$ \\
\hline *yupa- & 'to count' & & & Q \\
\hline \multirow[t]{4}{*}{ *yupi } & 'footstep' & & & Q \\
\hline & & *yuqa & 'son' & \\
\hline & & *yuqaKa & 'boy' & \\
\hline & & *yuqts'a & 'daughter-in-law' & \\
\hline *yura & 'plant' & & & Q \\
\hline *yuraq & 'white' & & & Q \\
\hline *yutu & 'partridge' & & & Q \\
\hline *yuyu & $\begin{array}{l}\text { 'tender, bud, shoot, } \\
\text { green vegetable' }\end{array}$ & & & $\mathrm{Q}$ \\
\hline
\end{tabular}

${ }^{1}$ Proto-Quechua *apta- 'to grasp, grab, carry in the hand, fist' appears to be lexicalized from the root *apa- 'to carry, bring' (shared by Proto-Quechua and Proto-Aymara), and the Proto-Aymara suffix *-(p)ta 'upward motion'. For this reason, I have not assigned it a provenance. The presence of such roots in Proto-Quechua illustrates the complexity of early Quechua-Aymara contact. 
${ }^{2}$ The /pa/ in *tsirapa 'mist, drizzle, sun shower, rainbow' may have originally been an independent morpheme, but since /tsira/ is not a known form, it has been left in the corpus.

${ }^{3}$ hampi- is one of a handful of roots that are attested with initial $/ \mathrm{h} / \mathrm{in}$ all Quechuan varieties except in Jauja (Central Peru), where they are /s/-initial (i.e. sampi-). Other such roots include hana / sana 'up, above, over'; hitsa- / sitsa- 'to spill, empty out a vessel, scatter'; and hirpu- / sirpu- 'to pour liquid or grains into a container, to stuff into'. Cerrón-Palomino (1987:175) argues that these Proto-Quechua forms were *s-initial, and that they underwent an $*_{s}>/ \mathrm{h} /$ change everywhere in the Quechuan family except in Jauja. The strength of this explanation is that this sound change is well known in the region, and that Jauja Quechua is conservative in many other respects. Parker (1971:5960 ), on the other hand, interprets these exceptions as originally $* h$-initial roots that underwent an $* \mathrm{~h}>/ \mathrm{s} /$ change as a result of hypercorrection. The strength of this explanation is that it does not require us to posit a sound change that affected the entire Quechua family, with the exception of one sub-variety. Pending further evidence, I have chosen to reconstruct these forms as *h-initial, while acknowledging uncertainty on this point.

${ }^{4}$ Proto-Aymara *mač'a 'fallow, dry season, to irrigate' may be related to *matsa- 'drunk, liquor, to be drunk', shared by Proto-Quechua and Proto-Aymara. However, given the mismatching affricates and the indirect semantic connection, I have chosen to treat them separately.

${ }^{5}$ Proto-Quechua *manta- 'to spread out fabric' appears to be related to other roots that refer to spreading (e.g. Proto-Quechua *masa- 'to spread out in the sun', and mašta- 'to spread out, lay flat', which is widespread across the Quechuan family). However, these roots cannot be analyzed as morphologically complex at the Proto-Quechua stage, but rather likely share a common, lexicalized monosyllabic Pre-Proto-Quechua root *ma 'to spread out'.

${ }^{6}$ Proto-Quechua *mitka- 'to trip, fall down, tumble' has undergone metathesis in some modern Quechuan varieties (e.g. Pacaraos tinka- 'to trip'). The Proto-Aymara form *t'inki- 'to fall, slip, tumble' appears to reflect this metathesis.

${ }^{7}$ waKpa, which is attested across the modern Quechuan and Aymaran languages, is usually glossed as 'chicken, hen'; however, since the chicken was introduced to the Andes during the colonial period, it is not clear what this term might have meant before that time. Thus, I have simply glossed it here as 'bird species'. One piece of evidence in support of its interpretation as a bird term is that it begins with /wa/, as in many other common bird terms in Quechua (e.g. wačwa 'goose species'; waKata 'goose species'; wayčaw 'songbird species'; wančaq wančaku 'bird species'; wayanay 'bird species'). 
(O2017 by The University of Chicago. All rights reserved.

\section{REFERENCES}

Cerrón-Palomino, Rodolfo. 1987. Lingǘstica Quechua. Cuzco: Centro de Estudios Rurales Andinos Bartolomé de las Casas. . 2000. Lingüística Aimara. Cuzco: Centro de Estudios Regionales Andinos Bartolomé de Las Casas.

Durston, Alan. 2007. Pastoral Quechua: The History of Christian Translation in Colonial Peru, 1550-1650. Notre Dame, Ind.: University of Notre Dame Press.

MANNHEIM, BRUCE. 2015. All translation is radical translation. Translating Worlds: The Epistemological Space of Translation, ed. C. Severi and W. F. Hanks, pp. 199219. Chicago: HAU Books.

PARKER, GARY J. 1969. Comparative Quechua phonology and grammar III: ProtoQuechua lexicon. University of Hawaii Working Papers in Linguistics 1:1-61.

PARKER, GARY J. 1971. Comparative Quechua phonology and grammar V: The evolution of Quechua B. University of Hawaii Working Papers in Linguistics 3(3):45-109. 